Florida International University

FIU Digital Commons

FIU Electronic Theses and Dissertations

University Graduate School

10-23-2019

\title{
How are Social Studies Teachers Using Technology in the Classroom?
}

Stephanie Delgado

Florida International University, stepdelg@fiu.edu

Follow this and additional works at: https://digitalcommons.fiu.edu/etd

Part of the Curriculum and Instruction Commons, Educational Technology Commons, Elementary Education Commons, and the Secondary Education Commons

\section{Recommended Citation}

Delgado, Stephanie, "How are Social Studies Teachers Using Technology in the Classroom?" (2019). FIU Electronic Theses and Dissertations. 4326.

https://digitalcommons.fiu.edu/etd/4326

This work is brought to you for free and open access by the University Graduate School at FIU Digital Commons. It has been accepted for inclusion in FIU Electronic Theses and Dissertations by an authorized administrator of FIU Digital Commons. For more information, please contact dcc@fiu.edu. 


\title{
FLORIDA INTERNATIONAL UNIVERSITY
}

\author{
Miami, Florida
}

\section{HOW ARE SOCIAL STUDIES TEACHERS USING TECHNOLOGY IN THE CLASSROOM?}

A dissertation submitted in partial fulfillment of

the requirements for the degree of

DOCTOR OF PHILOSOPHY

in

CURRICULUM AND INSTRUCTION

by

Stephanie Delgado 
To: Dean Michael R. Heithaus

College of Arts, Sciences and Education

This dissertation, written by Stephanie Delgado, and entitled How are Social Studies Teachers Using Technology in the Classroom?, having been approved in respect to style and intellectual content, is referred to you for judgment.

We have read this dissertation and recommend that it be approved.

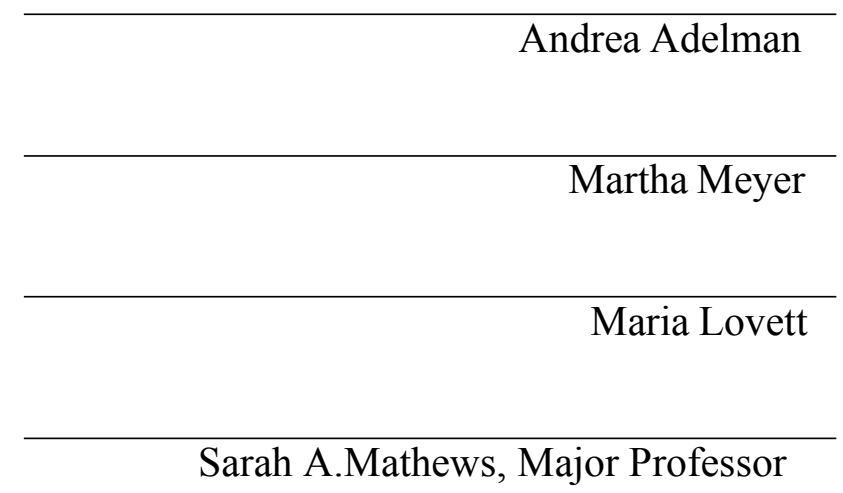

Date of Defense: October 23, 2019

The dissertation of Stephanie Delgado is approved.

Dean Michael R. Heithaus

College of Arts, Sciences and Education

Andrés G. Gil

Vice President for Research and Economic Development and Dean of the University Graduate School

Florida International University, 2019 
(C) Copyright 2019 by Stephanie Delgado

All rights reserved. 


\section{DEDICATION}

When I was a young girl my grandfather, who came to the United States escaping a communist regime in Cuba, told me that there were two things no one could ever take away from you, what you have in your head and what you have in your heart. He told me to prepare both, and so I did.

This dissertation is dedicated to everyone that has believed in me, supported me, and encouraged me to do better... it is also dedicated to those who doubted me a little but eventually gave in.

To my parents, thank you for all of the sacrifices you have made and continue to make for us and your grandchildren. I am the mother that I am because of the examples of unconditional love, patience, and support that you have shown me. Thank you for believing in me and for always reminding me that I am right and everyone else is wrong. Thank you for giving me the space to follow my own path, even if it was the road less traveled. I was testing you. You passed. To Ito, Jessica, Mari, and Franky, thank you for the codependency we share. I think we are pretty lucky to have each other, and now that Franky and I are done, I tag Jessica in. It's written down so now you have to do it. To Mandy and Cristy, this past year has probably been one of the toughest that our family has faced but the way that both of you have stepped in for us is something that I will always appreciate. Knowing that my dad and my mom had so much help and support while he fights this disease gave me the strength to engage in the research I needed to and write this dissertation. We are all so grateful. To Joshua, Sofi, Ceci, Mia, Theo, and Gabe, we have set the bar and expect all of you to do better than we have. Remember to make good choices. Don't be scared to take chances, don't be scared to fail and don't be 
scared to succeed. To Ingrid, thank you for your presence in our family and for everything you do for us. Thank you for reminding me that I have help and support, and that it's ok to call on those resources when I need to. I am very blessed.

To my baby Amilia: You are the light of my world. You have shown more strength and resiliency in your short time here than I have my entire life. You bring out the best in me and give me strength I didn't know I had. I hope that in completing this dissertation, specifically during this time in our lives, you can see that hard work and commitment pay off. Let this be a small example of how life is full of highs and lows, but these are just short fragments of time that will pass. I want you to hold the highs deep in your heart and use the lows to strengthen your character. I hope you always keep that resilient spirit you have. Keep your family close and always hold your head up high. Don't let anyone set your limits for you. You fought hard to be here with us, and I know that is because you are destined for greatness. I will always be here to help you follow your dreams, and to remind you that you can do anything you put your mind to. Joshua and Amilia - we love you both very much and we hope that as you get older and start your own lives that you never forget to look out for each other, support each other, and encourage each other to follow your dreams.

Last, but never least, to my partner in this world, my husband, my best friend Anthony. We did it! We finally finished this thing up. Thank you for reminding me that I had this in the bag. Thank you for letting me read the same paragraph to you over and over again and asking you if you liked it better the first time or the second time. Thank you for believing in me all those times I didn't. Thank you for giving me the space to break down and cry but remained close by waiting for me right outside the door. Only 
you know how hard this time has been because you have been right there beside me for all of it. Thank you for not letting me quit and for being excited about my progress. Thank you for bragging about me and for being proud of my accomplishments. Thank you for traveling with me to all my conference presentations so that I didn't have to leave Amilia behind and could focus on my work instead of worrying about her. Thank you for pretending you didn't hear me when I told you I was quitting the program. Thank you for giving me the time to read, think, and write even if it meant there was an additional workload falling on you. Thank you for your patience, your support, your love, and for our family. To everything I didn't have space to mention, thank you.

The completion of this degree was a collective effort. This degree was more than just finishing academic coursework and research. To me, completing this degree was about continuing this journey and never giving up during some of the happiest and hardest times of my life. To everyone that was there, thank you. 


\section{ACKNOWLEDGMENTS}

I would like to thank my chair, Dr. Sarah Mathews for all of your time, patience, and attention during this process. Thank you for not allowing me to stop when I felt I couldn't go anymore. I would not have been able to make it through this process without your support. I truly thank you. I would also like to thank Dr. Andrea Adelman for sharing your expertise in grounded theory and making sure that I was doing it right. Thank you for looking at my charts, graphs, coding conventions, and for making sense of all of it. Thank you for your reassurances, your confidence in me, and your excitement. Thank you to Dr. Martha Meyer and Dr. Maria Lovett for taking the time to be on my committee and providing me with resources to help guide my study. Thank you for your availability and your willingness to share your time and talents. From the moment I put this committee together, I felt I was so blessed to have this amazing panel of strong, accomplished, and wise women. Thank you for your confidence in my abilities and for your gentle guidance to help me do better.

I would also like to acknowledge all of the faculty who extended their compassion and allowed me flexibility during my pregnancy and after the birth of my daughter. Her early arrival made things challenging, but with your help, I was able to continue. Thank you for allowing me to leave a little early and make it home on time to feed her and put her to bed. Those are moments that we don't get back, and I am so blessed each of you allowed me to have that.

Finally, the completion of this dissertation would not have been possible without the support from the administrative staff, management team, and my colleagues at FIU Online. I would like to thank my friends at work for holding me accountable and 
reminding me that I was crazy for starting this but also, that I was almost at the finish line. Lastly, I would like to thank everyone at FIU Online and for all the opportunities the department has provided me with I am very thankful, and I am blessed to work for an organization like ours. 


\section{ABSTRACT OF THE DISSERTATION \\ HOW ARE SOCIAL STUDIES TEACHERS USING TECHNOLOGY IN THE CLASSROOM?}

by

Stephanie Delgado

Florida International University, 2019

Miami, Florida

\section{Professor Sarah A. Mathews, Major Professor}

So that students are equipped with the skills needed to compete a in a global economy, schools are being given resources intended to increase equity, opportunity, and to close the digital divide. Digital equity exists when all students have access to both advanced technologies and the learning opportunity the technologies provide (Solomon, Allen, \& Resta, 2003). The U.S. Department of Education notes that although students are graduating high school at high rates, performance gaps among students from low socioeconomic and various cultural backgrounds still exist. My study followed a constructivist grounded theory approach to examine how seven teachers in Miami-Dade County were using technology in their social studies classrooms and what they perceived to be both facilitators and barriers to their varying levels of classroom integration. The results of the current study indicated that these teachers were not necessarily opposed to integrating technology in their classrooms because of the technology itself, but rather, how they decided to use technology mostly depended on the types of students in each class. Teacher perception of student population and performance were the main determinants of technology integration. Teacher perception of students and their 
performance with technology, referred to as the fourth barrier to technology integration, adds to the work published by Ertmer (1999) and Tsai and Chai (2012) when they speak about First, Second, and Third Order barriers to technology integration in the classroom. As a result of the present study, more professional development geared towards the impact of teaching with technology on students who come from low socio-economic backgrounds, atypical learners (advanced and remedial), and non-English speakers should be incorporated into teacher preparation programs so that all students have an opportunity to access the resources the county is providing. 


\section{TABLE OF CONTENTS}

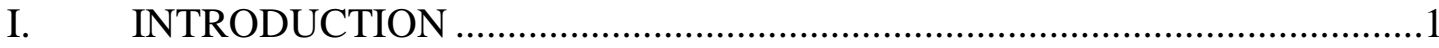

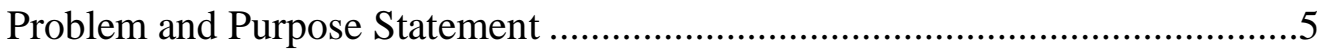

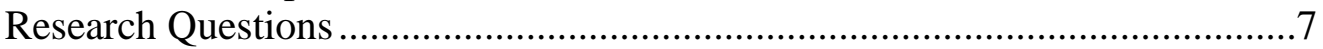

Methodology .......................................................................................

Conceptual and Theoretical Framework ....................................................

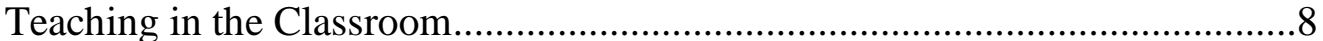

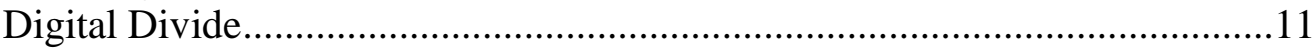

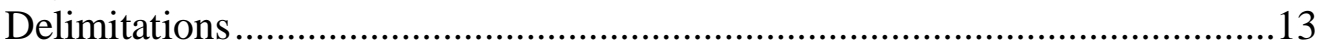

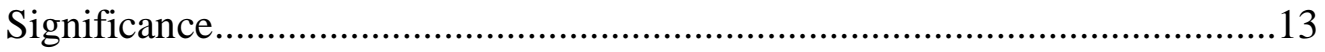

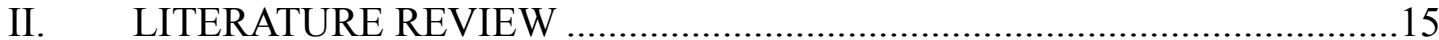

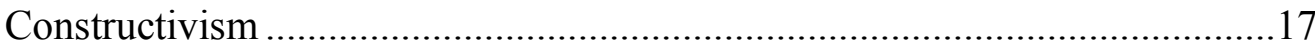

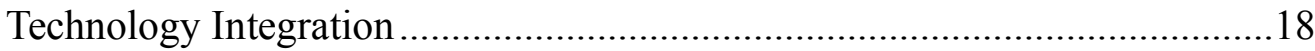

Social Studies and Technology Integration ...............................................21

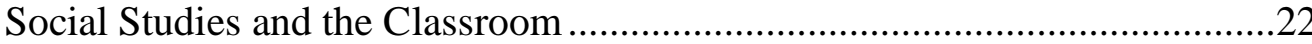

Models for Teaching with Technology - SAMR and TPACK.......................24

Technology for Instruction .........................................................................27

Barriers to Technology Integration ............................................................29

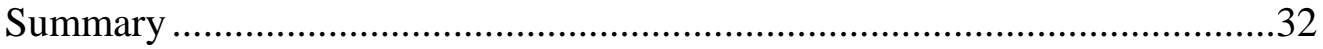

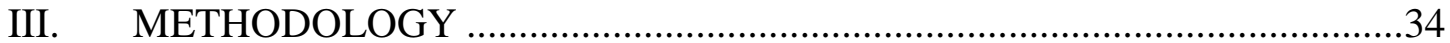

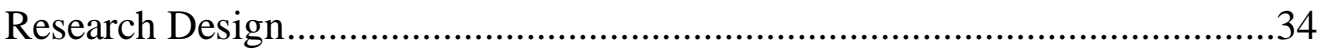

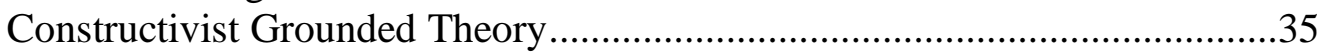

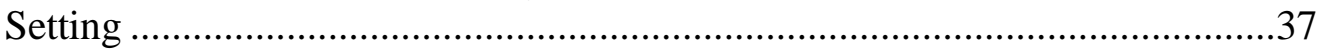

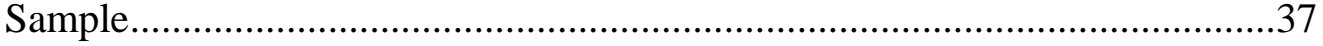

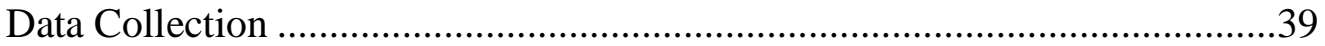

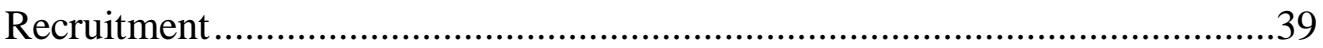

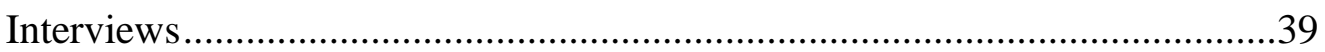

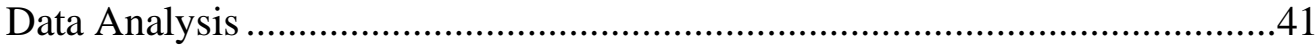

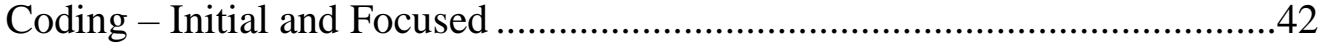

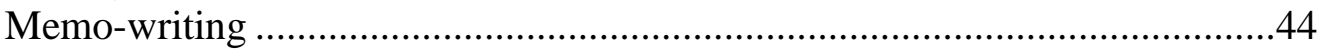

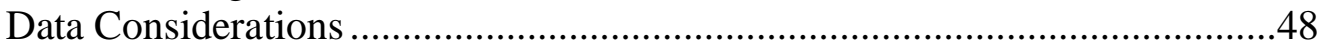

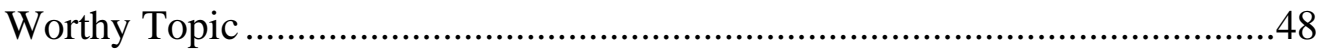

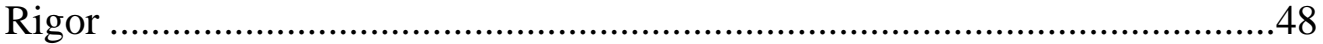

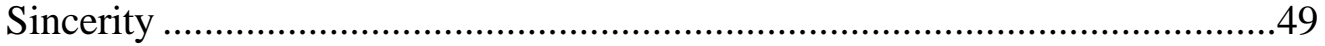

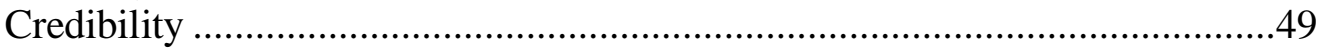

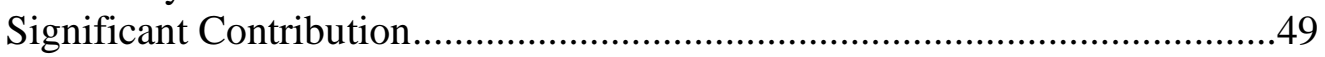




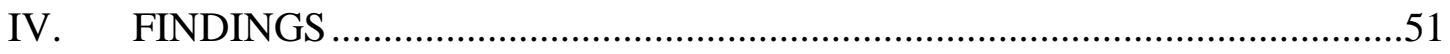

RQ1: How are social studies teachers using technology in the classroom?

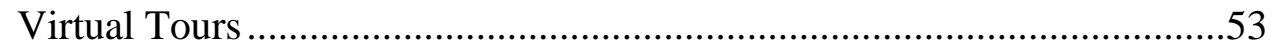

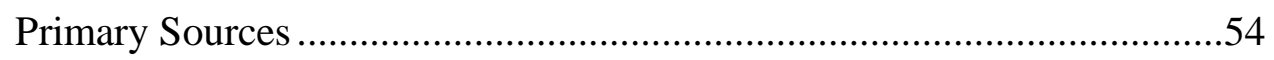

Student Engagement …………………………………………….....56

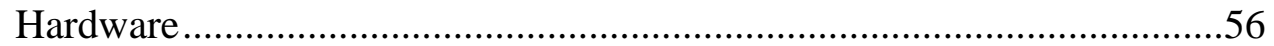

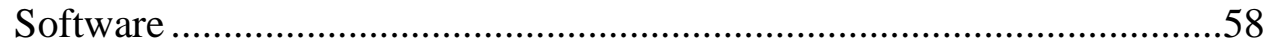

Curriculum Supplements .......................................................................62

Personal Development ……………………………………..................63

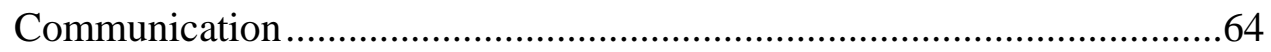

RQ2: What do social studies teachers perceive to be barriers to

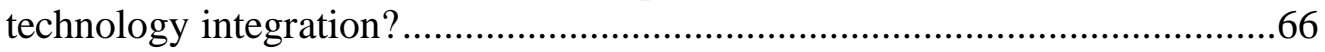

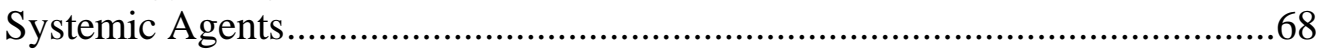

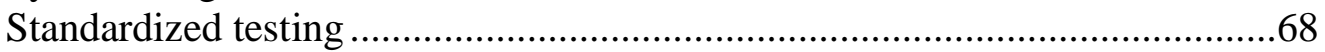

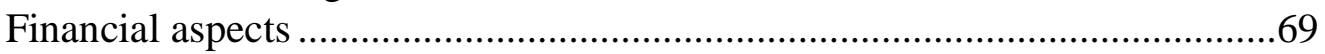

Internet connectivity …………………………………………….....71

Primary environment agents .....................................................................72

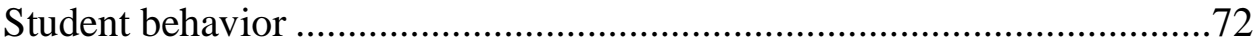

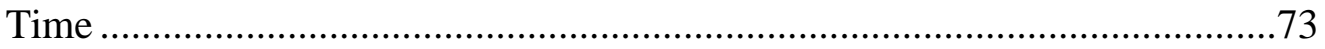

Teacher perceived inequities...................................................................76

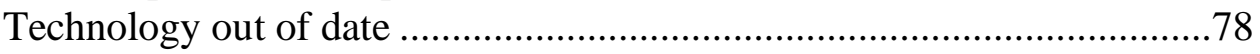

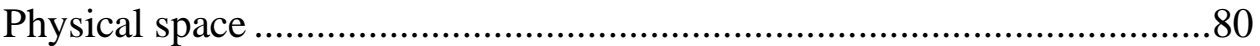

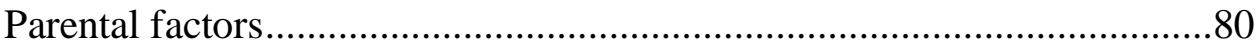

RQ3: What do social studies teachers perceive to be facilitators to

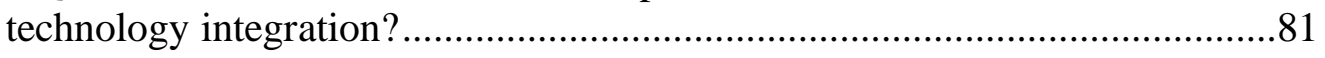

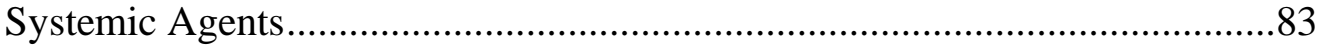

Professional development ......................................................................8 83

District sponsored tools (Digital Convergence Plan (2013)) .....................85

Primary Environment Agents ..................................................................... 86

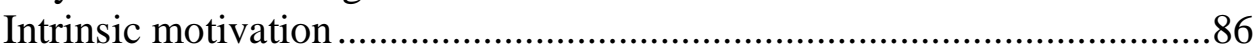

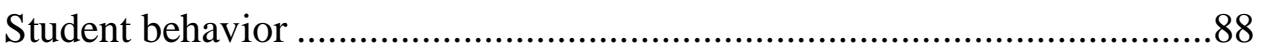

Increased access to personal mobile devices ..............................................8

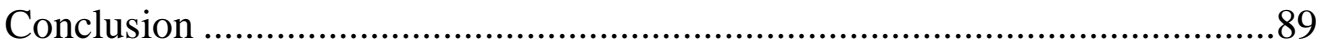

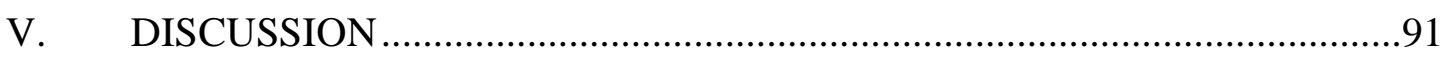

Interpretation of Findings .........................................................................93

Discussion of Barriers ..............................................................................99

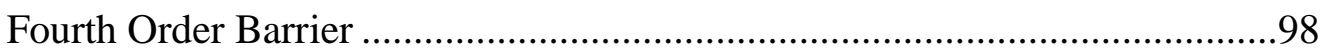

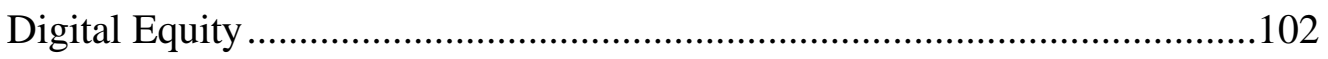




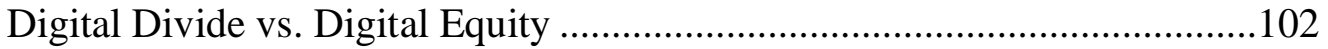

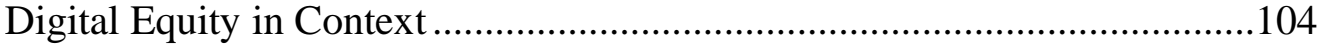

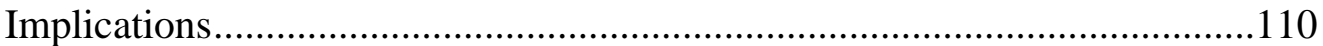

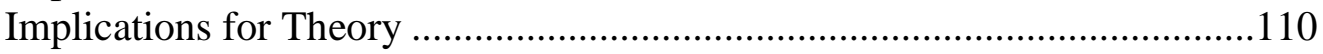

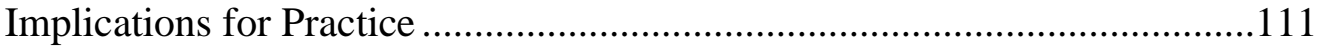

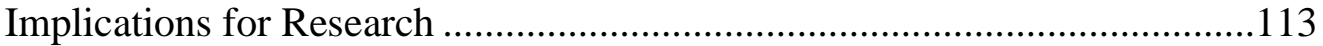

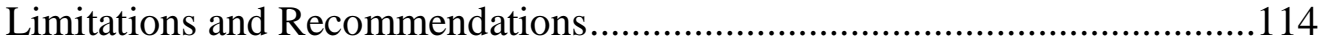

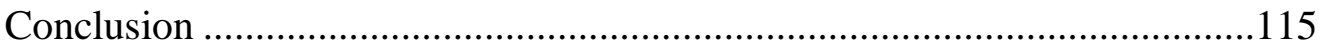

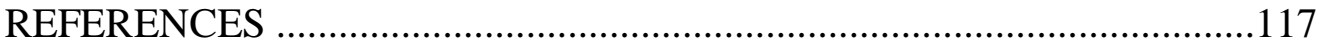

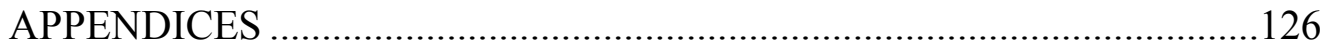

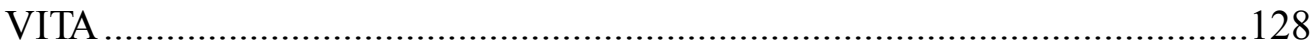




\section{LIST OF TABLES}

TABLE

PAGE

Table 1 Description of search criteria for literature review .......................16

Table 2 Demographic information for participants ..................................37

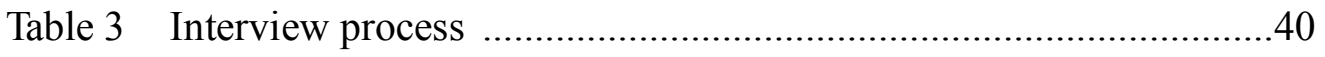

Table 4 Overview of uses of technology in the classroom .........................58

Table 5 Overview of Ertmer's (1999) First Order and Second Order

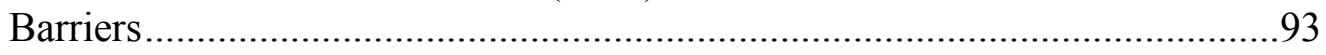




\section{LIST OF FIGURES}

FIGURE

PAGE

Figure 1 Visual representation of TPACK and SAMR Model..... .26

Figure 2 Overview of themes, categories, and summative statement for RQ1

Figure 3 Overview of themes, categories, and summative statement for RQ2

Figure 4 Overview of themes, categories, and summative statement for RQ3 .46

Figure 5 Flowchart representing how social studies teachers are using technology in the classroom?

Figure 6 Flowchart representing what social studies teachers perceive to be barriers to technology integration

Figure 7 Flowchart representing what social studies teachers perceive to be facilitators to technology integration .82

Figure 8 Flowchart representing how barriers were addressed by the Digital Convergence Plan (2013)

Figure 9 Flowchart representing the classification of teacher concerns into Ertmer's (1999) First Order and Second Order barrier 


\section{CHAPTER I}

\section{INTRODUCTION}

According to the International Society of Technology in Education, the incorporation of technology into schools is vital for the overall success of the student as learning about technology prepares students to be competitive in an ever-changing environment (Annual Report, 2017). The U.S. Department of Education (2019) states that using technology in the classroom can transform both teaching and learning by introducing new teaching strategies. Technology connects teachers and students to different resources and systems which assist with self-learning and differentiated instruction (U.S. Department of Education, 2019). Teachers are expected to provide students with the skills they need in order to compete and be successful in technologyrich global environments (Harris, 2016).

Forty-eight states and the District of Columbia now support some form of virtual learning in the public schools and institutions of higher education. In 2017, the national budget provided for $\$ 139.7$ billion in funding programs that are intended to advance educational equity within the public school system and to support teachers by providing additional professional development opportunities and school leaders at all levels (U.S. Department of Education, 2017). The U.S. Department of Education also notes that although students are graduating from high school at high rates, performance gaps between students of different groups still exist and one way to address this disparity in performance is by equitably increasing access to resources. School districts throughout the nation are developing and implementing state-level digital integration plans to help 
address issues relating to technological access (U.S. Department of Education, 2017). One of way of addressing equity of resources is by increasing student access to technology and related devices.

The Florida Department of Education's Bureau of Educational Technology (2019) provides resources to assist districts and schools with their integration plans. Miami-Dade County Public Schools (MDCPS) developed and published a Digital Convergence Plan (2013) to address technological resource equity (Schuster, 2013). The intent of the MDCPS Digital Convergence Plan (2013) is to transform teaching and learning and promote 21 st-century skills and digital equity both in schools and among students. The county wants to move away from teacher-centered instruction, passive learning, factual thinking, reactive responding, and traditional teacher-student information delivery models into a classroom environment that encourages multimedia presentations, collaboration among teachers and students, inquiry-based learning, information exchange, and critical thinking (Miami Dade County Public Schools, 2015). The plan aims to do this in part by increasing access to technology components and expanding professional development opportunities (Digital Classrooms Program, 2019).

The Miami-Dade County Public School district is considered the fourth largest district in the United States. There are 392 schools within the district with over 300,000 students (dadeschools.net). In 2013, Superintendent Alberto M. Carvalho (2008-present) authorized a digital convergence plan. Superintendent Carvalho stated the plan was not about "outpacing" others "in the pursuit of equity and opportunity" but that "Miami-Dade will lead the nation in guaranteeing universal digital rights for all citizens by 2014" (p.2). 
National policies are promoting the use of technology in communities, but these policies rarely address the needs of children, and since social environments are now digital as well then the rights of children need to be established and protected (Livingstone \& Bulger, 2014). In 1989 the United Nation's Convention on the Rights of the Child established minimal standards that should apply to all children. In 2009, these rights were extended to include that media and communication environments are now integral children's rights as well (Livingstone \& Bulger, 2014). In a press release (2013), Miami Dade County described the five main components of this plan:

1. updating the schools' internet access for all schools,

2. giving students access to digital devices,

3. adopting digital curricula,

4. using technology-rich schools as models for other schools, and

5. providing teachers with sufficient training for learning how to implement technology into their classrooms (Schuster, 2013).

All elementary schools were given laptops for students to use. This included providing laptops to be shared among classrooms (laptop carts) as well as individual devices for older children. Electronic tablets were given to 7 th and 9th grade social studies classrooms. In an effort to increase access, the 9th graders were permitted to take these tablets home.

Providing students with these types of technologies is very costly. A 21st Century School General Obligation Bond Referendum was approved by Miami voters in 2012. That fund included $\$ 100$ million to be allocated for technology upgrades in schools. Of 
this $\$ 100$ million, $\$ 82$ million was allocated for school campuses, with $\$ 38$ million to be applied towards screen projection systems, interactive technologies, and sound amplification systems for the school buildings including classrooms. School networks were allocated \$44 million for updating (Miami-Dade County Public Schools, 2013). These are were directly allocated for learner advancement with technology.

These funding opportunities allow the district to continue working to stabilize a continued access to technology. Every student and teacher within the county should now have access to technology within their schools and classrooms. Depending on their ages, all students are now guaranteed access to a technology device and a mobile hotspot (if needed by the student) in order to take home and can use. Although Superintendent Carvalho (2013) stated that approximately 8 million children are offline, the plan does not account for internet nor wired access to the internet in the home of the students. To address this gap in internet access, the plan provides access to mobile hotspots for students who not have internet connectivity.

The district's Convergence Plan's mission is to increase students' access to technology in this digital age (Miami Dade County Public Schools, 2013). By providing the same technology across all schools, the district attempted to provide equal access to all students within the county. Equal access is not the same as equitable access. According to Warchauer and Matuchniak's (2010), three guidelines for ensuring equity in technology use are to provide access. The criteria for access is to "consider[s] not only whether diverse groups of youth have digital media available to them but also how that access is supported or constrained by technological and social factors" (p. 181). Also to examine the Use of Technology. Equitable frameworks for technology should examine 
and utilize the ways diverse youth deploy media through social interactions, for entertainment, and to learn. Lastly to develop outcomes. This refers to developing equitable outcomes, educators should consider academic achievement, acquisition of 21st-century learning skills, and participation in technology-related careers.

Warschauer and Matuchniak (2010), also considered the physical availability of internet-connected computers an indicator for access. If schools have equal access to technology, two additional aspects might influence how technology is implemented in the social studies classroom: How teachers implement technology and the level of the integration in the classroom.

Having access to iPads and other types of mobile devices helps promote technology use, but the way in which teachers choose to integrate these into the curriculum is what impacts learning (Barrow, Anderson, \& Horner, 2017). Many times, technologies are integrated into the classrooms based upon experiences the teachers themselves had in their own education preparation courses (Vasinda, Ryter, Hathcock, \& Wang, 2017). According to Vasinda, Ryter, and Hathcock access is not enough, especially if not all education preparation programs have a technology integration component where preservice teachers can observe what effective instruction with how technology looks. School districts nationally are investing large amounts of resources into technology with the expectation that teachers will suddenly be able to enhance their classroom curriculum and meet the goals of the integration plans (Hilton, 2016). 


\section{Problem and Purpose Statement}

The $21_{\text {st }}$ Century Skills are a set of skills identified by government agencies and leading business organizations that have been said to prepare students for success in a global economy. These skill sets are divided into three main areas: learning and innovation skills, digital literacy and career and life skills (Trilling and Fadel, 2009). In an effort to support students and the development of these skills, schools have been given resources to increase equity, opportunity, and to close the digital divide. Digital equity exists when all students have access to both advanced technologies and the learning opportunities they provide (Solomon, Allen \& Resta, 2003). The U.S. Department of Education (2017) notes that although students are graduating high school at high rates, performance gaps among students of different groups still exist. For example, in MiamiDade County, White students are performing 37\% higher than Black students in mathematics, reading, and science (Nations Report Card, 2017). One way to address this concern is by improving technology resource equity. There are no implementation mandates by the district in place to ensure that teachers are using technology regularly and efficaciously in their classrooms and therefore not all students are benefitting from the digital convergence plans being developed by school districts. If school districts are granting schools money and resources to integrate technology in the classrooms, what teachers perceive as barriers or facilitators to the integration of technology in the classroom is imperative to study. The purpose of the current study is to explore what inservice teachers perceive to be the barriers or facilitators to the integration of technology in their classrooms. 


\section{Research Questions}

The following research questions guided this constructivist grounded theory study:

1. How are social studies teachers using technology in the classroom?

2. What do teachers perceive to be barriers to classroom technology integration?

3. What do teachers perceive to be facilitators to classroom technology integration?

\section{Methodology}

This research study is a constructive qualitative study and will rely on the following two models for the design of the methodology:

1. Charmaz's constructivist grounded theory model (Charmaz, 2006)

2. Patton's methodology for qualitative interviewing (Patton, 2002)

\section{Conceptual and Theoretical Framework}

Although the terms access and use are sometimes used interchangeably, they refer to two different behaviors regarding digital technology. Access refers to the availability of the hardware or software. If teachers want to incorporate more computer use in their learning activities, then students need greater physical access to computers, related software, and connectivity (Van Roekel, 2008). An issue of access is when have an insufficient amount of hardware or software or there is inadequate bandwidth for students to effectively use the hardware/software. Access is what students first need in order to use and engage with technology. Use, for the purpose of the current study, will refer to how the technology is incorporated into the learning environment and what opportunities exist for students to use and access these in school. 
Researchers (e.g., Ertmer \& Ottenbrelt-Leftwhich, 2013; Van Roekel, 2008) are finding that there are obstacles to increasing access to technology and with teacher's effective use of the technology once there is access. These obstacles are also noted by Funkhouser and Mouza (2013) posit that educators struggle with incorporating technology into classroom routines and instruction. The struggle of teachers lies in the transition of philosophical beliefs on the roles of teachers. Area teachers the giver of knowledge or the facilitator of learning? This is also recognized by Bitner and Bitner (2002) when they note integrating technology "alters the traditional paradigm of the teacher providing wisdom and the student absorbing knowledge" (p. 97). Students absorb knowledge when they are engaged, and Ryan and Bagley (2015) state incorporating technologies, in the form of hardware and software, in the classroom positively increases student engagement. A shift into a technologically rich classroom where the teacher is a facilitator of knowledge requires teachers to change their lesson plans and activities and to make a cognitive shift from a behaviorist way of teaching to a constructivist one. Therefore, perceived barriers and facilitators to the integration of technology, specifically hardware and software, in the classroom should be critically explored.

\section{Teaching in the Classroom}

The National Council for the Social Studies (NCSS) (1994) noted that technology was an effective way to engage students in authentic problem-posing skills (Freire, 1996). Technology allows students to engage in critical thinking and active decision making, enabling them to be constructors of their own knowledge. Having the technology accessible in the classroom addresses part of the pedagogy and can aid teachers in 
creating higher levels of critical thinking, developing problem-solving skills as well as helping students develop their communication skills (Chai \& Kong, 2017). A "major benefit for social studies teachers who integrate technology to support constructivism in the social studies include the ability to obtain relevant information in the form of documents, photographs, transcripts, video and audio clips" creating the opportunity for students to engage in experiences that would not otherwise be possible (Rice \& Wilson, 1999, p. 29). The use of technology in social studies classrooms can positively influence instruction. The goal would be for teachers to use commonly "applied techniques to diffuse and integrate technological concepts into the curriculum" (Kormos, 2019). Providing teachers with more training and practice in pedagogy can assist them in learning how to better integrate technology into their classroom.

In 2016, NCSS made conceptual changes to how social studies should be taught. The NCSS promoted constructivist teaching strategies which included the use of technology (Krahenbul, 2016). For students to have access to computers and related software, teachers need to want to learn how to use them and must believe that computers and all related technology will advance learning in the classroom as well as prepare the student for success. These changes do not happen overnight though. As Kormos (2019) states, incorporating technology into the classroom is a slow and length shift because it is a dynamic process which must consider many different aspects. The change in programmatic standards along with the incorporation of technology, allows students the opportunity to construct their own knowledge by gaining access to different perspectives which otherwise would not be possible. 
Research indicates that although teachers and schools may have access to technologies, there are still many barriers to incorporating technology. Some barriers are poverty, federal and local spending on education and technology, school environments, teacher preparation, and professional development that prevent the effective and proper implementation of these resources in the classroom (Bolick, 2017; Solomon \& Allen, 2003). Although the issue of access is being addressed on a national and state level, issues relating to equitable opportunity for use by all students still linger. Because there are varying levels of how students get to use technology in the classroom, it may put some students at a disadvantage.

When students can apply technologically supported learning to real-world contexts like problem-solving and data manipulation, they have a real advantage but when students can apply the learning to real-world contexts it is even more profound (Shifflet \& Weilbacher, 2015). The incorporation of technology in pedagogical practices is a change that can have a broader impact. As Shifflet and Weilbacher (2015) suggest, the proper integration of technology into the classroom has the opportunity to change the culture. Students can learn about global social justice issues, but "seeing" them or gaining access to people who live them, again, may have a greater impact. The effective integration of technology can allow students to have these types of large-scale, global experiences.

\section{Digital Divide}

In 1997, President Bill Clinton discussed how the internet was expected to be a catalyst in transforming society and creating new ways of learning. In anticipation of this, 
he challenged that every classroom and library in the country to have internet access by the year 2000. During this same time period, there were additional societal expectations for all homes to be wired with internet (Hoffman, 1998). With some students having access to the internet, and others not having access, there was a new type of divide created, coined the "digital divide" (Van Dijk, 2012, p. 315).

In an attempt to get ahead of the digital divide, lawmakers both on national and local levels moved towards the establishment of policies that would increase the availability of technology in schools. In 2001, Attewell asked if simply creating policies that increase availability is enough to reduce the social inequity referred to as the digital divide? Research tends to focus on the physical access to computers and the internet either at home or school (Warschauer, Knobel, \& Stone, 2004). Dolan (2016) explains that access to technology encompasses more than just having a computer. Access includes issues related to the type of internet connectivity and bandwidth available at home and school are factors. Additional in school factors include types of software, teacher's use of software, teachers' knowledge and skills related to the use of technology and mobile technology. External factors such as poverty, teacher training, and the establishment of relationships between teachers and students also play a significant role when it comes to access. Darling-Hammond (2000) indicates the most notable condition which can hinder student success is teacher preparation and quality of teaching because of the fact that poor preparation and inadequate quality of teaching can deprive children of equal access to various learning experiences. 
Historically in American society, movements surrounding access have been about “expanding citizen participation” from narrow political bases (Butler \& Wiburg, 2003, p.1). Pockets of society have identified inequities and attempted to address these inequities, but also historically, the laws enacted to protect and equalize access have not been effective (Butler \& Wiburg, 2003). In regard to accessing technology in schools, it is noted that students are experiencing "disparities in access, use, proficiency and interests that mirror similar academic and social inequities" (Collin \& Brotcorne, 2019, p.1). Digital equity is being considered the "latest battle in the effort to keep access to power open to all- to avoid having a technology Berlin Wall between those who have access to electronic information and communication and those who do not" (Butler \& Wiburg, 2003, p.1). Pasey et. al (2018) state although technology has brought about many positive changes, one of the biggest challenges still being faced is that technology is created and managed by individuals and corporations and then given to the people, and educators should have a say in how that technology is developed and distributed to ensure equitability across many levels.

Because access is multidimensional, there exists the digital divides of access and use. The first level of the digital divide represents a lack of physical access to computers in schools and at home. The second level divide refers to the social differences in how computers are used at school and at home (Attewell, 2001). The digital integration plans throughout the nation and specifically the Digital Convergence Plan (2013) for Miami Dade County Public Schools address the first level divide. 


\section{Delimitations}

One of the delimitations of this study is that teachers only in MCPS or Miami Dade County Charter Schools were selected as participants. The only teachers who were considered for participation were those that taught social studies in grades 6-12 within the last academic year. Teachers who had taught social studies in grades 6-12 in other academic years were not considered for the study. Data was collected via interviews only and no classroom observations were conducted. As a result, the study only includes selfreport of teachers and how they integrate technology into the classroom and what they perceive to be barriers or facilitators to the eventual integration of technology.

\section{Significance}

The conversation regarding equity in instruction and equality in schools has shaped policies and called for reform, the digital integration plans is just one of these examples. With the emphasis on the use of technology in schools, school districts are taking measures to ensure that students have equitable access to hardware and software. The question is, does increasing access to hardware and software create equity? "It is debatable whether we can have 'equity' and 'equality' in a society that prioritizes efficiency in resource management over social justice" (Espinoza, 2007, p.3). Wei and Hindman (2011) suggests the digital divide "affords an opportunity to identify the inequalities between the technological haves and have-nots (p.2). The Digital Convergence Plan (2013) by the district was implemented to ensure that all students had access to technology devices thus providing the opportunity for the development of 21 stcentury learning skills (ex: digital literacy). Unfortunately, policymakers tend to combine 
equity with "fair distribution" (Eubanks, 2012, p.25). I explored if equal access to technology and related resources was provided to schools, are the classroom environments accessible for learning with technology and did it ensure equitable instructional practices and student access.

I wanted to explore if the development and implementation of the Digital Convergence Plan (2013) facilitated the adoption and adaptation of technology in the classroom. The level of implementation of technology into the classroom instruction could potentially be positively or negatively influenced by appropriate teacher training and preparation made available by resources from the Digital Convergence Plan (2013).

One of the $21_{\text {st }}$ century student preparation objectives is that students are prepared to compete in a global economy and workforce (i.e.: digital skills learning). To foster this type of learning students should have the opportunity to appropriately use technology in both inside and outside of the classroom (Davis, Fuller, Jackson, Pittman, and Sweet, 2007). Knowing if students are being given the opportunity to use technology is important because learning how to use technology will act as a catalyst in discontinuing the cycle of the marginalization of students from underserved communities, particularly in this new digital era (Reinhart, Thomas, and Toriskie, 2011). Understanding implications of technological inequities is also important because how technology is implemented in the classroom is up to the teacher. Unless it is mandated by the school administration or initiated by the teacher, there is no guarantee that students will even be given the opportunity to efficaciously use the hardware or software - exacerbating the phenomenon referred to as the digital divide. 


\section{CHAPTER II}

\section{LITERATURE REVIEW}

With the development and implementation of national, state, and local digital integrations within the school districts it is important to identify what teachers perceive the barriers for them in using and taking advantage resources being made available to schools within the district. It is also critical to explore what aspects facilitate the integration of technology into the classroom in order to ensure the overall success of student development. Chapter 2 provides a comprehensive overview of research that served as a premise for the following questions:

1. How are social studies teachers using technology in the classroom?

2. What do teachers perceive to be barriers to classroom technology integration?

3. What do teachers perceive to be facilitators to classroom technology integration?

The areas to be explored include: (a) social studies education and the different hardware, software, and applications that teachers are incorporating into their teaching, (b) social studies education and what teachers are reporting to be hindrances into technology integration in the classroom and (c) how social studies are using technology in the classroom and the resources made available to them that support implementation.

An exhaustive search of electronic resources and databases was conducted using various search engines to access the following: Education Resources Information Center (ERIC), ProQuest, Google Scholar, PsychInfo, Journal of Social Studies Research, Social Studies Research and Practice and the FIU university library database was used to access 
the online versions of CITE, TRSE and the Journal of Technology. Published scholarly articles, online articles, government publications and reports, and publications from local and national organizations were accessed for this research. Please refer to Table 1.1 for keywords, inclusion criteria, and databases used.

Table 1.

Description of search criteria for literature review

\begin{tabular}{|c|c|c|c|}
\hline $\begin{array}{c}\text { Literature } \\
\text { Review } \\
\text { Component }\end{array}$ & $\begin{array}{l}\text { Database } \\
\text { Searched }\end{array}$ & Keywords & Parameters \\
\hline $\begin{array}{l}\text { Social studies } \\
\text { and technology } \\
\text { integration }\end{array}$ & $\begin{array}{l}\text { Google scholar, } \\
\text { ERIC, } \\
\text { university } \\
\text { library } \\
\text { database, } \\
\text { Journals: CITE, } \\
\text { TRSE, Journal } \\
\text { of Technology } \\
\text { Education }\end{array}$ & $\begin{array}{l}\text { Social studies \& } \\
\text { TPACK, Social } \\
\text { studies ICT, } \\
\text { Social studies } \\
\text { and technology, } \\
\text { Technology and } \\
\text { teaching, } 21_{\text {st }} \\
\text { century learning } \\
\text { skills }\end{array}$ & $\begin{array}{l}\text { Used } \\
\text { foundational } \\
\text { studies but tried } \\
\text { to limit articles } \\
\text { to post } 2005, \\
\text { included articles } \\
\text { on other content } \\
\text { areas, not just } \\
\text { social studies } \\
\text { due to a lack of } \\
\text { information }\end{array}$ \\
\hline $\begin{array}{l}\text { Technology and } \\
\text { motivation }\end{array}$ & $\begin{array}{l}\text { Google scholar, } \\
\text { PsychInfo, } \\
\text { ERIC, } \\
\text { university } \\
\text { library } \\
\text { database, } \\
\text { Journals: CITE, } \\
\text { TRSE, Journal } \\
\text { of Technology } \\
\text { Education }\end{array}$ & $\begin{array}{l}\text { Motivation and } \\
\text { technology, } \\
\text { Motivation and } \\
\text { social studies, } \\
\text { Motivation in } \\
\text { K-12, } \\
\text { Increasing } \\
\text { student } \\
\text { performance } \\
\text { with technology }\end{array}$ & $\begin{array}{l}\text { Included } \\
\text { articles on how } \\
\text { technology can } \\
\text { increase student } \\
\text { performance in } \\
\text { social studies, } \\
\text { but expanded to } \\
\text { other content } \\
\text { areas due to a } \\
\text { lack of } \\
\text { information }\end{array}$ \\
\hline
\end{tabular}




\begin{tabular}{|c|c|c|c|}
\hline $\begin{array}{l}\text { Social studies } \\
\text { teaching beliefs }\end{array}$ & $\begin{array}{l}\text { Google scholar, } \\
\text { PsychInfo, } \\
\text { ERIC, } \\
\text { university } \\
\text { library } \\
\text { database, } \\
\text { Journals: CITE, } \\
\text { TRSE, Journal } \\
\text { of Education } \\
\text { Psychology }\end{array}$ & $\begin{array}{l}\text { Constructivism } \\
\text { and social } \\
\text { studies, } \\
\text { Behaviorism } \\
\text { and social } \\
\text { studies, } \\
\text { Teaching beliefs } \\
\text { for K-12 }\end{array}$ & $\begin{array}{l}\text { Researched } \\
\text { articles about } \\
\text { traditional } \\
\text { teaching } \\
\text { strategies in } \\
\text { social studies } \\
\text { and teacher } \\
\text { beliefs for all } \\
\text { other content } \\
\text { areas }\end{array}$ \\
\hline $\begin{array}{l}\text { Barriers to } \\
\text { technology } \\
\text { integration }\end{array}$ & $\begin{array}{l}\text { Google scholar, } \\
\text { ERIC, } \\
\text { university } \\
\text { library } \\
\text { database, } \\
\text { Journals: CITE, } \\
\text { TRSE, Journal } \\
\text { of Technology } \\
\text { Education }\end{array}$ & $\begin{array}{l}\text { Perception of } \\
\text { technology \& } \\
\text { social studies, } \\
\text { Barriers to } \\
\text { technology, } \\
\text { Teachers not } \\
\text { using } \\
\text { technology, } \\
\text { Helping } \\
\text { teachers use } \\
\text { technology, } \\
\text { First order } \\
\text { beliefs and } \\
\text { technology }\end{array}$ & $\begin{array}{l}\text { Used } \\
\text { foundational } \\
\text { studies on first } \\
\text { order and } \\
\text { second order } \\
\text { barriers to } \\
\text { technology } \\
\text { integration, and } \\
\text { how perception } \\
\text { of teaching } \\
\text { influences } \\
\text { technology } \\
\text { integration }\end{array}$ \\
\hline
\end{tabular}

\section{Constructivism}

The main theory underlying the present study is Piaget's constructivist theory. Piaget was a psychologist with specific interest in the cognitive development of children. Piaget (1983) stated that children have a specific conceptual growth, and in order for them to learn, the environment needs to complement their different cognitive stages. Piaget expressed that constructivism meant that people create meaning of things and gain knowledge on the basis of their experiences. In a Constructivist-style classroom, teachers act as facilitators to the construction of knowledge by guiding students through their 
learning. For example, a teacher in a Constructivist-style classroom does not lecture students on a topic, to then follow up with an exam. Constructivist teaching methods guides the learners by actively involving them during the process of learning and guiding them towards the construction of their own knowledge. Students are encouraged to think critically, reflect, and ask questions themselves (McLeod, 2018). Through the art of discourse, teachers and students work together in creating understanding and knowledge of concepts and skills (Kalina \& Powell, 2009).

Ackerman (2001) discusses three implications Piaget's theory of constructivism has for classroom instruction. These are:

1. Indirect teaching: children use the knowledge they already have to observe and interpret the learning environment in order to create new understandings of the things around them.

2. Transmission model won't work: Piaget does not believe that knowledge can simply be transmitted. People need to directly interact with the world in order to create knowledge.

3. Learning theories need to account for resistances to learning as well: Piaget believed that children have strong worldviews and have "good reasons to not abandon these views in the light of external perturbations" (p. 3)

\section{Technology Integration}

Mandating the incorporation of technology into the classroom may not lead to desired results. Whereas some teachers may welcome the challenge of adding technology into the learning environment, for others the thought of technology integration is 
overwhelming. In 2001, Harris and Sullivan indicated that asking teachers to integrate technology into the classroom was asking them to change in two ways: asking them to learn new tools and asking them to change how they teach children in their classrooms.

As Howard and Mozejko (2015) state, in order for technology to transform learning, teachers need to be willing to take risks and radically change their current teaching practices. Ultimately, research suggests teachers will not "embrace the new technology until they see a need for it" (Firmin \& Genesi, 2013, p. 1604). Embracing the new technology is critical for student gains because it not the technology itself that leads to learning gain, it is "the change in processes of teaching with digital technologies" that creates the transformation (Howard \& Mozejko, 2015, p.3)

Changes in the classroom are not so easy to make (Howard \& Mozejko, 2015). Teachers already have a system that works. The teacher has been conditioned, and the students have been conditioned. Asking teachers to abandon strategies and techniques to try something else can induce fear and anxiety. As Bitner and Bitner (2001) state, "adults do not change easily. Change of any kind brings about fear, anxiety, and concern" (p. 96). Since change of any kind can cause anxiety and fear, if a teacher is already unsure about the efficacy of the new software the fear of the change and the lack of knowledge in regard to incorporating the change, will definitely act as a barrier.

Embracing new technologies means that teachers need to learn how to use and how to teach through a different mechanism. They must un-condition themselves from their regular routine and patterns established and create new ones. It is a large undertaking. "Educators are often inclined to be traditionalists; therefore, they are not as 
eager to latch on to the latest technological advancement that has just come out on the market" (Firmin \& Genesi, 2013, p. 1604). Educators need to believe in the value of the new strategy before it is adopted (Yoo, 2016; Kleinsasser, 2014).

Over twenty years ago the National Council for the Social Studies Education stated their "vision of powerful social studies teaching and learning" which requires integrative and active learning (NCSS, 1994, p. 162). These expectations is where the intersection between traditional methods of teaching begin to conflict with current expectations. Doolittle and Hicks (2003) suggest that the curriculum should be reformed by "implementing an aligned constructive philosophy, theory, and pedagogy in pursuit of the development of critically minded global citizens" (p.97). The authors also suggest if social studies teachers are just using technology to cover more information more rapidly, and not changing their teaching strategies, then the benefit of actually use the technology is lost. Educators need not just use technology, such as PowerPoints to facilitate lectures. They need to truly understand the critical and integral part technology plays in the development of learning and construction of knowledge. Jonnasson, Peck, and Wilson (1999) dub this a transition from technology as the teacher to technology as a partner.

\section{Social Studies and Technology Integration}

The incorporation of technology into daily lives has forced some people in society to function differently. Incorporating technology into schools requires teachers and students to "rethink how they teach and learn" (International Society for Technology in Education, n.d.; Ertmer, Ottenbreit-Leftowhich, Sadik,Sendurur, \& Sendurer, 2012). As a result, nationally funded digital convergence plans have been established to help states 
transition schools from learning environments where technology use is limited, to one where it is used openly and in a manner that supports student learning. The development and incorporation of these convergence plans mean that schools now have computers, mobile devices, and other types of hardware and software available for use that can be integrated into the learning environment and are available for student use.

Aside from increasing the availability of technology and related hardware into schools, there have been other advancements such as the types of technologies that are being made available in schools, changes in professional development modalities: online trainings and face to face; and the types of software programs available to teachers (Berson, Berson, \& McGlinn, 2012). Now that all teachers and schools should have increased access to technological hardware and software, how are they using it?

Social Studies and the Classroom. Social Studies teachers have many options when it comes to integrating technology into the classroom environment. Recent studies on the effects of engaging students in activities such as political simulations (like voting) have shown that students will retain acquired content and performance skill sets when interest is triggered (Lo, 2015; Parker \& Lo, 2016). Hardware and software are becoming more powerful and more economical which is increasing the opportunity for consistent integration and more opportunity to trigger interest (Berson, Berson, \& McGlinn, 2012; Parker \& Lo, 2016). In social studies classrooms, “drill and practice programs are now accompanied by interactive software, and innovations in hypermedia, telecommunication, and peripheral devices allow teachers to develop more robust lessons. Traditional tools such as Webquests, interactive geography games, and productivity tools are being combined with more complex applications that can capture student interest, increase 
engagement and can facilitate learning (Doering, Koseoglu, Scharber, Henrickson, \& Lanegran, 2014; Doolittle \& Hicks, 2009; \& Lo, 2015);

With the advancement of productivity tools, along with digital integration into the curriculum standards, availability of hardware and software, and the increasing number of teachers who participate in technology-rich professional development (Kleiman, 2004), it would be reasonable to think that that teachers are using technology in their classrooms more than ever. Research indicates that teachers are not necessarily changing how they deliver their contents to students. Although the availability of hardware, software, and training may have increased and become easier for teachers to attain, the determining factor as to whether or not these new learning tools will be used in the classroom is still critically dependent on teacher beliefs about the use of technology in the classroom (Chen, 2008; Davies \& West, 2014).

There are many opportunities for teachers to integrate technology into social studies classrooms and the availability of technology, such as free software and increased access to hardware, should make access to technology more convenient. The Florida Department of Education (www.fldoe.org) has resources for social studies teachers. For example, there is a link to a digital storytelling website that provides students with opportunities to see historical Florida photographs as well as audio-video recordings that students can use to do research on primary sources for projects. For teachers using digital storytelling, the website has step-by-step guides on how to conduct the lessons.

Resources like these exist for American history, civics, government, economics, financial literacy, geography, humanities, psychology, sociology, and world history (National Council for the Social Studies, 2019). Some of these resources even assist with cross- 
subject technology - such as Social Studies and Language Arts and Social Studies and Reading.

Social Studies programs have historically been slow to integrate information communication technologies (ICT) into the curriculum (Doering, Scharber, Miller, \& Veletsianos, 2009). In fact, over twenty years ago social studies programs were referred to as a "sleeping giant" (Ayas, 2006; Martorella, 1997, p. 2,). Martorella suggested that students were showing a lack of interest in their social studies courses because the lecture based teaching strategies being used were boring and un-engaging. When appropriately implemented, technology can increase student engagement and interest. Therefore, it is possible that with the proper integration into the classroom, technology can change how students view social studies education.

\section{Models for Teaching with Technology - SAMR and TPACK}

Social studies teachers need to approach the integration of technology into the classroom in a systematic manner (Hilton, 2017). This will ensure that not only the explicit (outwardly stated) learning targets are met, but that he implicit (incidentally learned) ones are met as well (i.e., valuing the contribution technology can have on learning). Successful integrations begin when the integration itself is embedded within the curriculum content, such as using multimedia to deliver a lecture, and planned learning experiences; secondly, when there is fluency with how to use the technology and its applications (Harris, Mishra, \& Koehler, 2009). With that in mind, there are two main technology integration models suggested by scholars for use when planning curricula. These are the Technology, Pedagogy, and Content Knowledge model (TPACK) and the Substitution, Augmentation, Modification, and Redefinition Model (SAMR) (Hilton, 
2016). The TPACK model consists of seven components that interconnect in order to provide a learner with well-rounded experiences.

The model attempts to help teachers identify what is required for appropriate technology integration. Because of the transactional relationship between the curriculum, intended use of technology and actual use of technology, teachers must prepare themselves properly by familiarizing themselves with pedagogical principles and integration best practices (tpack.org). According to TPACK, there are three main forms of knowledge that should be explored when integrating technology into instruction: content, pedagogy, and technology (Harris, Mishra, \& Koehler, 2009). Social studies teachers have reported that using the TPACK model has helped them inform their practices and be more reflective about their teaching (Harris \& Hofer, 2011; Hilton, 2016). Using the TPACK model teachers were able to transform themselves from teacher-centered environments and strategies, into more of a facilitator role and concentrating on the process the student goes through to learn content. The TPACK model was one that was seen as more integrative and holistic, as opposed to the SAMR model. Because of the linear design of the SAMR model, teachers feel that reaching the Redefinition phase is a final outcome (Hilton, 2016). The social studies teachers viewed the SAMR model as a framework to transform specific learning activities and not necessarily teaching style.

The SAMR model, created by Dr. Ruben Puentedura (2013) has been adopted by MDCPS as part of its digital integration plan. It was created to assist teachers with the implementation of technology into their classrooms. The model takes educators through four different cognitive stages of student learning: (a) Substitution refers to when the 
technology incorporated acts as a direct substitute or tool with no functional change in use; (b) Augmentation is when the technology has some functional change but still acts as a direct substitute for instructional tool (ex: handout vs. PowerPoint); (c) During the modification stage technology provides opportunities for student learning tasks to be redesigned; and (d) At the redefinition stage the technology allows for the creation of new tasks that would otherwise not have been possible (Puentedura, 2013). When properly implemented the SAMR model guides educators, who have access to technology and are willing to use it, in transforming their classroom activities from passive learning environments into creative, exciting, and engaging activities (www.schrockguide.com). Currently, trainings currently available through the county are not set up in manner that shows teachers how to reach the Redefinition phase of the SAMR Model. Professional development trainings are mostly geared towards how to use the software or technology itself, not necessarily how to implement it into specific classrooms. Teachers do have the option to request more specific trainings through the county. The SAMR model is able to guide teachers on how to incorporate technologically rich learning activities into their lessons in a manner that will help better connect students to the content and also to the technology. Although the SAMR model can be subjective, it still provides teachers with a guide on how to evaluate their level of integration and the potential learning outcome that may have for students (Romrell, Kidder, Wood, 2014). Because of the linear design of the SAMR model, teachers feels that reaching the Redefinition phase is a final outcome (Hilton, 2016). The social studies teachers viewed the SAMR model as a framework to transform specific learning activities and not necessarily teaching style. The SAMR model is typically represented as a ladder and encourages teachers to move-up the ladder 
by creating more rich and dynamic learning experiences for students. Although adopted by the district, the model has been criticized for its lack of foundation in a theoretical framework. This lack of theoretical explanation and foundation creates a certain level of subjectivity leaving the opportunity open for various interpretations of the four levels (Hamilton, Rosenberg, and Akcaoglu, 2016). The authors also state that although the model has its challenges, it still serves as a tool which can help teachers begin to transform their teaching strategies.

Figure 1 is an illustrative summary of both models:

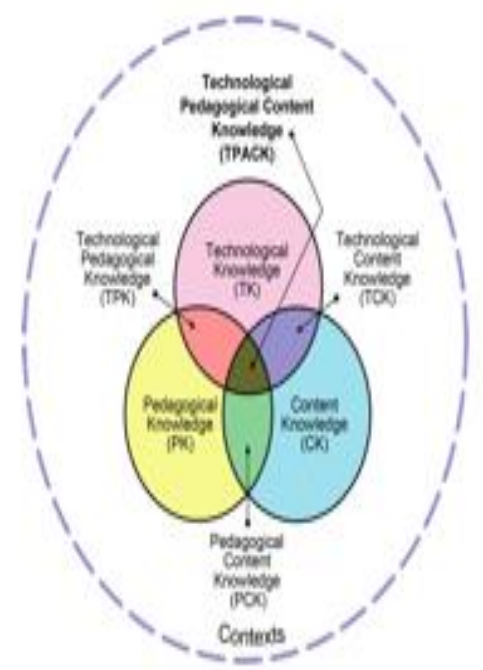

http://www.tpack.org
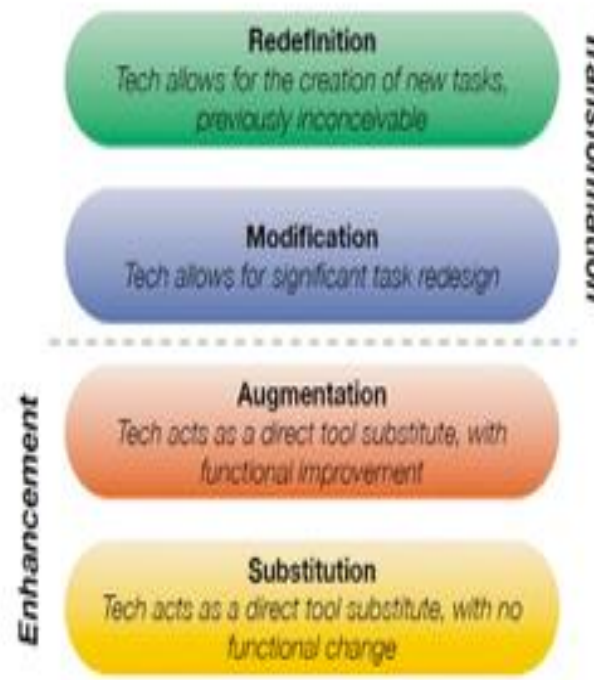

http://www.hippasus.com/rrpweblog/

Figure 1. Visual representation of TPACK and SAMR Models

\section{Technology for Instruction}

Traditional instructional methods, within typical social studies classrooms, such as lecturing and using PowerPoints, has caused a lack of interest and engagement from 
students (Heafner, 2004). Technology has the ability to motivate students by engaging students into the content. If the classroom teacher can learn how to successfully incorporate technology tools that are engaging to the students, then the level of motivation should increase as well (Gopalan et al., 2017). The conceptual shift from teacher-centered classrooms to student-centered environments will aid in promoting cognitive growth in a space where students feel nurtured and engaged (Heafner, 2004, p. 49). A student-centered learning environment may ultimately require a philosophical shift on behalf of the teacher.

Motivation has been said to be a determining factor in students' levels of engagement and contributions within a specific learning environment (Gopalan et al., 2017), and if teachers can adequately motivate students then there is a higher probability that their engagement with the content and performance will increase as well. Heafner (2004) emphasized that this is particularly true in social studies classrooms; because students equate something that is uninteresting with something that is unimportant, there is a lack of motivation to actually learn the content. A lack of student interest translates into a lack of student motivation, and is a problem that many teachers face, not just social studies teachers.

If the classroom teacher can learn how to implement technology tools that are engaging to the students, then the level of motivation may increase as well (Stockwell, 2013). The shift from teacher-centered classrooms to student-centered environments will aid in promoting cognitive growth in a space where students feel nurtured and engaged (Heafner, 2004, p. 49). As Ayas (2006) states, students enjoy learning new things by doing them, discovering them, and interacting with them. 


\section{Barriers to Technology Integration in the Classroom}

The notion that a small percentage of teachers are implementing the use of technology in their classrooms, even after having physical access to computers, has been researched for over twenty years (Carver, 2016; Ruggiero \& Mong, 2015; Tondeur, Van Brakk, Ertmer \& Ottenbreit-Leftwich, 2017). Even though millions of dollars are poured into schools for the advancement in the use of technology for teaching and student purposes, integration is still very low (U.S. Department of Education, 2019). In September 2018 , the Federal Government approved a budget increase of $\$ 581$ million, for a total $\$ 1.17$ billion for education spending (U.S. Department Budget Summary, 2018). The Federal money is intended to be applied to help schools in part to create a technology-rich environment for students. Additionally, $\$ 15.9$ billion is being granted nationally to Title 1 schools to "ensure that all children have a fair, equal, and significant opportunity to obtain a high-quality education" (Molnar, 2018). Some of the $\$ 15.9$ billion will be allocated to technology development in schools. With all of these resources in place to help students succeed, why are teachers not taking advantage of them?

Aside from money being granted to schools, there are other structural factors in place that affect the eventual integration of technology into the classroom. With the MiamiDade County Public School system being the fourth largest district in the nation, the school system is structured in a way that even though the money is being made available it is still difficult for students to access the resources they actually need. Providing the funds for technology integration without changing the structure of the system does not benefit the students because those who are making the decisions are not necessarily looking at school problems from an equity lens. For example, according to the MDCPS Organization chart 
published in October 2019, the Office of Education Equity, Access, and Diversity is at the bottom of the system. Before the Office of Education Equity, Access, and Diversity are consulted regarding the policies and processes expected to be integrated into the schools, these policies and implementation plans are first filtered through the Central Regional Office, Deputy Superintendent, and Superintendent of Schools. The outlined process does not even account for administrative and structural factors within the school itself that can further affect student access. The organizational charts published by the Miami-Dade County Public School system do not reflect the role of the teacher or school administration in the decision-making process; specifically, as to how curriculum redevelopment or technology integration should be represented in the classroom (Miami-Dade County Public Schools, 2019). The people who are being affected by the decisions are far removed from the decision making process. In order to really address barriers to technology integration, the perspective of the practitioners is critical for plan reform and structure reform.

Although the Digital Convergence Plan (2013). was created to address the issues of equity and student access to technology and related components, the many administrative and political levels involved make actual integration of technology for teachers in the classroom difficult. This separation of teachers and development of policy can contribute to the personal and professional obstacles that are preventing teachers from moving forward with technology integration into the classroom, even after the issues of physical access have been addressed. The Digital Convergence Plan (2013 focuses primarily on tangible, measurable resources that can be easily identified as provided or not provided, and not so much of the personal obstacles that teachers may be experiencing. 
Research refers to obstacles that teachers experience regarding technology integration as barriers. Barriers that teachers have reported as determining factors to technology integration in the classroom are classified into two categories: first order (external) and second order (internal) (Bricker, 1995; Cuban, 1993). Bricker (1995) describes first order barriers to be "obstacles which impede the effective implementation of a projected change or innovation" (p. 6). First order obstacles are typically referred to as items that can be quickly fixed in order for the change can be implemented. An example of this would be increasing physical access to computers and technology access for teachers and students in schools. The first order barriers are easily identifiable by teachers and therefore can be addressed quicker (Bricker, 1995). The national and state level convergence plans typically address these first-order barriers. These are the items that can be quantified and accounted for in a much easier fashion than second order barriers can be. Second-order barriers to change are also obstacles that impede implementation of changes, but these are "intrinsic in nature in that they are internal to the teacher"; typically, these are the barriers to change that "teachers do not like to admit that they exist" (Bricker, 1995, p. 6). Ertmer (1999) expands on the notion of first order and second-order barriers to change and describes how the relationship of these barriers actually hinder technology implementation into the classroom, in an attempt to improve overall teacher agency with regard to technology integration. In 2012, Tsai and Chai suggested a third barrier to technology integration also existed. Tsai and Chai argued that once first order and second order barriers were addressed, teachers still needed guidance with instructional design and conceptual reorganization of their learning materials and activities. 
In furthering Ertmer's study on why teachers were not integrating technology into their classrooms, Brush and Glazewski (2010) developed and tested an instrument to assess teachers' skills, beliefs, and barriers scale regarding the implementation of technology. A total of 32 items were developed to assess the technology scale subset (basic operation, productivity software, communication, electronic references, world wide web, and multimedia); 12 items were developed for the beliefs portion of the scale; and ten items were developed to measure perceived barriers for teachers (Brush \& Glazewski, 2010). By using the survey, the researchers were able to identify patterns as to what teachers determined to be barriers to the adoption of technology when it came to teaching in their classrooms. Recurring themes included teacher efficacy in regard to teaching with technology, teacher knowledge on how to use the software, teacher support in regard to using new technology, and teacher beliefs on the impact of student learning when traditional methods are replaced or enhanced with new strategies (Brush \& Glazewski, 2010).

\section{Summary}

As Piaget expresses, children learn best when they have the opportunity to construct their own knowledge, and the integration of technology into schools allows for just that. Technology, when properly implemented, has the ability to improve student learning and teacher instruction. The federal, state, and local level governments also understand the critical role that technology plays when it comes to preparing students for global citizenship. As such, funding been made available to assist schools with the adoption of technology into teacher classrooms and curricula (digital textbooks). 
Integration, adoption, and adaptation do not generally occur instantaneously, and such drastic changes are typically not well received.

Although there is much published information on the importance of technology in general, and even in specific fields such as reading, science and math, literature is minimal regarding technology integration in the social studies specifically. There is not much literature available on how social studies are using technology to teach students, nor how technology is being used to enhance the curriculum. 


\section{CHAPTER III METHODOLOGY}

This qualitative study served two purposes. The first purpose of this was to explore how teachers have integrated technology into their social studies classrooms. Secondly, it was to identify what teachers perceived to be either barriers or facilitators to technology integration. The outcome of this study generated a theory as to why teachers are not integrating technology into the classroom and factors that facilitate integration. It is through the understanding of how teachers are using technology in their classrooms and what is either aiding or preventing that integration that would benefit all students so that they each have a superior learning experience.

This qualitative study was guided by the following questions:

1. How are social studies teachers using technology in the classroom?

2. What do teachers perceive to be barriers to classroom technology integration?

3. What do teachers perceive to be facilitators to classroom technology integration?

\section{Research Design}

The present qualitative study used constructivist grounded theory explored how specific teachers used technology in their classrooms, and what they perceived to be barriers or facilitators for that integration. Interviews and follow-up interviews were conducted to gain insight into teaching practices, teaching philosophies, and applications of technology in the classroom. A semi-structured interview guide was used to ensure that all participants were asked the same questions, with response-specific follow-up 
questions. The interview questions were derived from the Technology Beliefs and Technology Skills survey published by Brush and Glazewski (2010).

Constructivist Grounded Theory. This study employed a constructivist grounded theory research design. Constructivist grounded theory derives from other versions of grounded theory proposed by Glaser and Strauss (1967) and then later by Strauss and Corbin (1997). Grounded theory is a methodology that guides the researcher in structuring, organizing, and analyzing data in a systematic way (Charmaz, 1996). The basic tenets of grounded theory are as follows:

1. Continuously collecting data and analyzing simultaneously

2. Allowing the data to guide the creation of codes and code categories

3. Developing mid-range theories

4. Memo-writing

5. Theoretical sampling

6. Postponing the literature review until the end of the study

There are some fundamental differences in constructivist grounded theory and classic grounded theory. In classic grounded theory the researcher enters the study as a blank slate, and so the literature review is done after the investigation. In constructivist grounded theory, the literature review is viewed as preparation for the field work and data collection process. Additionally, Charmaz (1996) recognized that dissertation committees as well as International Review Boards require students to complete literature reviews prior to engaging in research. She referenced that a second literature review can be completed after the data have been analyzed and the 
codes have been created. The literature review becomes specific to the categories of data that have been constructed after analysis. The second literature review is much narrower than the first.

Arguably, the biggest difference between constructivist and classic grounded theory, is that constructivist grounded theorists believe that theory is constructed and does not necessarily emerge from the data. Constructivist grounded theory rejects the notion of emergence and objectivity (Charmaz, 2006; Glaser \& Strauss, 1967). Constructivism aligns with my own worldview. I believe researchers need to go beyond the surface in seeking meaning in the data, searching for and questioning tacit meanings about values, beliefs and ideologies. Realities are constructed through our own experiences, reality is not found and does not emerge. Then, the internal process of making sense of those experiences is what constructs perceptions and beliefs. Therefore, it is only logical the data are gathered, coded, and analyzed are processed by the researcher and a theory that is influenced by personal experiences, perceptions, and beliefs is constructed. The influence of personal experience and belief is a strength and a limitation of this type of methodology.

Unlike classical grounded theory, constructivist grounded theory starts with a question in mind. In classical grounded theory the researcher wants to know more about a topic and the questions emerge as the data collection process begins. As Mills, Bonner, and Francis (2007) state, in order for the research design to be strong, the researcher must choose a paradigm that is "congruent with their beliefs about the nature of reality" (pg. 2). 


\section{Setting}

The study took place in Miami-Dade County, Florida. All participants were inservice teachers within the Miami-Dade County School system. All interviews were conducted virtually using the Zoom $\odot$ application, and participants had the option to turn their cameras on or off. During the initial interview, only two out of seven participants opted to keep their cameras on. During the follow-up interview, six participants decided to turn their cameras on. Zoomø sessions were facilitated through the use of a privatelyowned laptop that was dedicated solely to the research study while data were being collected, analyzed, and through the conclusion of the study. Both interview sessions with each teacher lasted between 45 and 60 minutes. Although the . Zoomø application permitted me to conduct interviewers more conveniently, a drawback was that when participants had their cameras turned off I was not able to assess visual cues such as facial expressions and other non-verbal cues. I do feel though, that the anonymity of the application allowed participants to feel more comfortable with providing information they felt was sensitive.

\section{Sample}

Participants were in service 6th -12 th grade social studies teachers. They were purposefully chosen for this study. The qualifying criteria for participation in the study addressed employment status and content area taught. Participants were currently teaching or taught within the past academic year from the date of data collection. Participants were currently teaching or have taught social studies courses. Since the goal of the study was to determine how social studies teachers were using technology in the classroom, and what perceived barriers or facilitators existed to the use of technology, the criteria above satisfied 
the purpose and there was no other exclusionary criteria. The table below reflects more specific information related to the participants:

Table 2.

Demographic information for participants

\begin{tabular}{|l|c|l|c|l|l|}
\hline $\begin{array}{l}\text { Participant } \\
\text { Pseudonym }\end{array}$ & Gender & $\begin{array}{l}\text { Highest } \\
\text { Degree }\end{array}$ & $\begin{array}{l}\text { Years of } \\
\text { Experie } \\
\text { nce }\end{array}$ & $\begin{array}{l}\text { Attends } \\
\text { Profession } \\
\text { al } \\
\text { Developm } \\
\text { ent }\end{array}$ & $\begin{array}{l}\text { Self-Rated } \\
\text { Level of } \\
\text { Fluency } \\
\text { with } \\
\text { Technology }\end{array}$ \\
\hline George & M & Master's & 3 & Yes & $\begin{array}{l}\text { Above } \\
\text { Average }\end{array}$ \\
\hline Albert & M & Master's & 10 & Yes & Average \\
\hline Sandra & F & Master's & 25 & Yes & $\begin{array}{l}\text { Below } \\
\text { Average }\end{array}$ \\
\hline Alex & M & $\begin{array}{l}\text { Bachelor } \\
\text { 's }\end{array}$ & 5 & Yes & Average \\
\hline Jorge & M & $\begin{array}{l}\text { Bachelor } \\
\text { 's }\end{array}$ & 2 & Yes & Average \\
\hline Ana & F & Master's & 6 & Yes & Average \\
\hline Christy & F & $\begin{array}{l}\text { Bachelor } \\
\text { 's }\end{array}$ & 8 & Yes & $\begin{array}{l}\text { Below } \\
\text { Average }\end{array}$ \\
\hline
\end{tabular}

Note. Participant information in relation to gender, education, experience, attendance of professional development, and self-rated level of fluency with technology

Sample sizes in qualitative research tend to be smaller than in quantitative research, as qualitative researchers are searching for a deeper understanding of a specific phenomenon. The intent is not to generalize a situation or context; therefore, smaller sample sizes are acceptable (Dworkin, 2012). Glaser and Strauss (1967) state that saturation has been reached when the data is not adding any new information on the issue being investigated. For this study, there were seven teacher participants and saturation was reached. Charmaz (2006) asserts the aim of the study will be the driving force in 
determining sample size and that saturation will supersede sample size, even if this means the sample size is very small.

\section{Data Collection}

The purpose of the study was to collect rich data so that a significant analysis could take place. Two data points were explored for this study and occurred through interviews with each of the participants. The following data points were explored:

1. Initial interviews with in-service teachers regarding their current use of technology in social studies classrooms. The interviews explored what inservice teachers perceived as barriers or facilitators to the integration of technology into their classroom learning environments.

2. A follow-up interview with each of the teachers. In this interview, participants were asked if the analysis of their initial interviews aligned with the participant's interpretation of the process (member-checking).

Recruitment. With the help of committee members, peers, and colleagues, seven participants were recruited for the study. Initial contact took place via email and text messaging. After being selected, the researcher provided participants with a consent form from Florida International University. Participants electronically submitted the forms through e-mail and were reminded to keep a copy for themselves.

Interviews. Interviewing is considered to be an appropriate and useful method for exploring experiences (Patton, 2002). In fact, because of open-ended nature of both interviewing and grounded theory, interviewing for data collection aligns with the methodology of grounded theory (Charmaz, 2006). Glaser (1978) stated that instruments, 
such as interview guides, forced data to fit into the researcher's quest and the researcher was not allowing him/herself to let the data guide them. Charmaz proposes that structured open-ended interview guides help novice researchers think through how to phrase and present open-ended questions so that they are more prepared. She states that an interview guide, which is open-ended, is not the same as having preconceived codes assigned. Following Patton's (2002) guidelines, a structured open-ended interview protocol was initially developed for this study, but ultimately the interview questions became semistructured as flexibility was needed in order to appropriately follow-up the teacher responses (see interview protocol Appendix A).

The structure of the interviews followed Patton's (2002) guidelines for conducting semi-structured interviews. The semi-structured interviewing technique requires the researcher to outline general questions that are going to be explored with each participant and serves mostly as a checklist. Patton (2002) suggests that researchers interview people so that unobservable data can be extracted from the participants because "we cannot observe feelings, thoughts, and intentions. We cannot observe behaviors that took place at some previous point in time. We cannot observe situations that preclude the presence of an observer" (Patton, 2002, p. 340).

Once participants signed the consent forms and the forms were securely stored in a password protected file on a laptop being used exclusively for the purpose of the study. The participants were informed they would be asked to participate in two interviews, and then asked to select a time and day in which the first interview could be conducted. Interviews were conducted via the Zoom॰ application. Zoom॰ provides a secure 
connection for tele-communicating. The Zoom@ application recorded the audio portion of the interview only. Recordings were stored on the password protected hard drive of the computer. The Zoom॰ application provided interview transcripts automatically after each session. Transcribed interviews were stored on the password protected hard drive of the computer.

A description of the interviews is included below. Interview protocols are included in the appendix. The first interview began on March 15, 2019 and were completed by March 26, 2019. Following the initial interviews, the data were analyzed and coded. The follow up interviews began on April 29, 2019 and were completed by May 10 2019. Both of the participant interviews were pre-scheduled to ensure availability, but the follow up interviews were rescheduled because coding required additional time. Table 3 represents an overview of the interview process.

Table 3.

Interview process

\begin{tabular}{|l|l|l|l|l|}
\hline Participants & $\begin{array}{l}\text { Number of } \\
\text { Interviews per } \\
\text { Participant }\end{array}$ & $\begin{array}{l}\text { Length of each } \\
\text { Interview }\end{array}$ & Format & Transcription \\
\hline $\begin{array}{l}\text { 7 In-Service } \\
\text { Teachers }\end{array}$ & 2 & $45-60$ minutes & $\begin{array}{l}\text { Standardized } \\
\text { open-ended }\end{array}$ & $\begin{array}{l}\text { Audio } \\
\text { recorded and } \\
\text { transcribed } \\
\text { verbatim }\end{array}$ \\
\hline
\end{tabular}

Note. Breakdown of interviews, number of participants, duration and format of interviews.

\section{Data Analysis}

The analysis of the data were conducted using Charmaz's (2006) suggestions for data analysis in constructivism grounded theory. A description of each phase follows. All interviews were conducted via Zoom॰, and transcribed via the same application. Zoom॰ 
has an accuracy rate of about $89 \%$. Transcripts were verified while listening to the audio to ensure the transcription was accurate. Both the audio and the transcribed data were uploaded to NVivo, a computer-based organizational tool that helps store, organize, categorize, and retrieve data. NVivo permits for data to be uploaded as either text, audio, images, and surveys. NVivo is password protected. This ensures that participant information is kept private and protected.

The NVivo software was used to assign codes, categorize codes, write memos relating to each code and potential instances of the codes. Ultimately, the NVivo software assisted the me in organizing the data into categories and charts were created from the data. The organization of categories and charts permitted visual review of the data and final analysis.

Coding - Initial and Focused. Coding for this research study will is defined as segmenting data "with a label that simultaneously categorizes, summarizes, and accounts for each piece of data" (Charmaz, 2006, p. 43). Coding is the link between data collection and the emerging theory (Charmaz \& Belgrave, 2007). The data coding occurred in two phases: initial coding and focused coding.

After each interview, the transcribed data was segment coded. In constructivist grounded theory there are different ways to code the data. For this study, segment coding was used. Line by line coding was used when appropriate. The approach seemed to be the most practical for the study because line by line coding allows the researcher to identify "implicit concerns as well as explicit statements" (Charmaz, 2006, p. 50).

The constant comparative method (Charmaz, 2006) was used throughout the data collection and analysis process. This method continuously compares new data emerging 
from the interviews with data that has already been coded and analyzed. At this point, I was looking for similarities and differences in the data that had already been analyzed. In the present study, interviews that were being coded and analyzed, were compared against previous interviews to ensure that all data was being accounted for.

After the initial coding phase, a more focused approach was taken. During focused coding, the codes were synthesized and explained. The codes across interviews were used to find larger, emerging codes or themes. As the interviews were coded, they were also compared against previous coded interviews and coded again to see if other incidents or statements could be applied or were "illuminate[d]" others (Charmaz, 2006, p. 59).

After a major category or code was identified, conceptual categories assisted in linking the categories with the subcategories. The conceptual categories were described and applied to the emerging codes. The subcategories address the condition, action, or consequence in order to link the subcategory to the category. Although not necessary, I felt applying the conceptual categories helped to encapsulate the codes and conditions. In the present study, these conceptual categories helped to extend the vision of the codes and reduce any ambiguity (Charmaz, 2006).

Last within the phase of focused coding is theoretical coding. I developed theoretical codes to help me identify possible relationships between the larger codes. The use of theoretical codes helped me to similarities between the data and group them in a way that could explain the phenomena that was emerging from the data.

Memo-writing. During the process of analyzing data and generating codes, memo writing was conducted simultaneously. Memo writing allowed me to stay engaged 
with the data by giving me an opportunity to make notes about the interviews while coding. These notes would be later reviewed to verify if they were applicable to the coding and analysis process. The memos were used to capture thoughts on the data, codes, categories, concepts and their relationship with each other. Figures 2, 3, and 4 are a snapshot of the codes, categories and themes for each research question: 


\begin{tabular}{|c|c|c|c|}
\hline RQ1: & How are social studies teachers using technology? & & \\
\hline Summative Statement: & \multicolumn{3}{|c|}{$\begin{array}{l}\text { When talking about how teachers use technology in their classrooms, they mentioned using technology to take students on virtual } \\
\text { field trips, helping students enhance their research for projects, trying to increase student engagment through interactive activities, } \\
\text { supplementing content from the textbook, practice their presentation skills, and they also mentioned how technology allows them to } \\
\text { communicate with students easier. }\end{array}$} \\
\hline Theme 1: Virtual Tours & Theme 2: Primary Resources & Theme 3: Student Engagement & Theme 4: Curriculum Supplements \\
\hline Conceptual Category & Conceptual Category & Conceptual Category & Conceptual Category \\
\hline $\begin{array}{l}\text { Virtually visiting other people and } \\
\text { places }\end{array}$ & $\begin{array}{l}\text { The internet to find historical documents including } \\
\text { older news recordings }\end{array}$ & $\begin{array}{l}\text { Ways teachers try to use technology } \\
\text { to engage students }\end{array}$ & $\begin{array}{l}\text { Resources teachers use to } \\
\text { supplement their lessons }\end{array}$ \\
\hline Selection of Open Codes: & Selection of Open Codes: & Selection of Open Codes: & Selection of Open Codes: \\
\hline $\begin{array}{l}\text { "I think they connect on a deeper } \\
\text { level, you know, when I cover India } \\
\text { or China." - George }\end{array}$ & $\begin{array}{l}\text { Reviewing historical documents - Declaration of } \\
\text { Indepence, Bill of Rights, Articles of Confederation }\end{array}$ & $\begin{array}{l}\text { "we create memes and political } \\
\text { cartoons" - Ana }\end{array}$ & $\begin{array}{l}\text { "The district is going greener by } \\
\text { using digital textbooks, and with that } \\
\text { comes publisher integrations from } \\
\text { like Pearson" - George }\end{array}$ \\
\hline Google Street & Older news videos & Websites to get research for projects & access to McGraw Hill \\
\hline Google Arts & Youtube for videos & Weebly to create personal websites & \begin{tabular}{|l} 
"Khan Academy has like full lesson \\
plan units with assessments and \\
everyting" - Albert
\end{tabular} \\
\hline \multirow[t]{2}{*}{$\begin{array}{l}\text { "We had an activity where they } \\
\text { walked through Medina" - George }\end{array}$} & Researching old newspaper publications & $\begin{array}{l}\text { NearPod "they really get on board } \\
\text { with it" - Ana }\end{array}$ & \\
\hline & & Scratch by MIT & \\
\hline Theme 5: Personal Development & Theme 6: Communication & FlowLab & \\
\hline Conceptual Category: & Conceptual Category: & Storyboards & \\
\hline $\begin{array}{l}\text { Developing skills needed for the } \\
\text { future }\end{array}$ & Ways to communicate with students & & \\
\hline Selection of Open Codes: & Selection of Open Codes: & & \\
\hline $\begin{array}{l}\text { "They have to go up and present } \\
\text { their PowerPoints. That's a big } \\
\text { deal for them" - Albert }\end{array}$ & Email & & \\
\hline \multirow[t]{6}{*}{$\begin{array}{l}\text { "I use it in a way that can related to } \\
\text { possible real world careers" - Ana }\end{array}$} & Remind & & \\
\hline & Personal websites & & \\
\hline & Edmodo & & \\
\hline & Social Media & & \\
\hline & Sharing classroom information & & \\
\hline & [I don't have to give out my personal information" - Alex & & \\
\hline
\end{tabular}

Figure 2: Overview of themes, categories, and summative statement for RQ1 


\begin{tabular}{|c|c|c|c|}
\hline$R Q 2:$ & \multicolumn{2}{|c|}{ What do teachers perceive as barriers to technology integration? } & \\
\hline Summative Statement: & \multicolumn{3}{|c|}{$\begin{array}{l}\text { When teachers spoke about the factors that prevented them from moving forward with technology, they mentioned factors outside } \\
\text { of their control such as; having to deal with end of course exams, the instability of the internet, principals not allowing them } \\
\text { access to professional development trainings, or having to take sick days to attend the trainings. The teachers also talked about } \\
\text { factors that were specific to their classrooms, such as; working with inclusion classrooms, students in Advanced Placement not } \\
\text { having space in the curriculum for technology, the technology in their classrooms being out of date, parents not wanting students } \\
\text { to access the mobile devices the county offers, and not having enough time to learn and implement the technology into their } \\
\text { lessons. }\end{array}$} \\
\hline Theme 7: Systemic Agents (Barriers) & Theme 8: Primary Environment Agents (Barriers) & & \\
\hline Conceptual Category & Conceptual Category & & \\
\hline Factors outside of the teachers' control & $\begin{array}{l}\text { Factors directly related to the teacher, student } \\
\text { related or personal }\end{array}$ & & \\
\hline Selection of Open Codes: & Selection of Open Codes: & & \\
\hline EOC (end of course exams) & Student Behavior & Socioeconomic factors with students & \\
\hline Standardized Testing & Not enough time to learn how to use it & Tech out of date & \\
\hline $\begin{array}{l}\text { "If you have one of the EOC classes } \\
\text { then all your content needs to be } \\
\text { completed by April" - George }\end{array}$ & Not enough time to attend the trainings & \multicolumn{2}{|c|}{ Classroom space not comfortable for students } \\
\hline "The WiFi isn't always stable" - Sandra & Need more time to plan lessons and back up lessons & $\begin{array}{l}\text { "Look, if you have a class with } 10 \\
\text { inclusion kids and you have to } \\
\text { spend } 20 \text { minutes of your class time } \\
\text { waiting for those kids to catch up, at } \\
\text { some point you are just going to say, } \\
\text { it's not worth it" - George }\end{array}$ & \\
\hline Internet doesn't work & $\begin{array}{l}\text { "After I learn how to use it, I need time to figure out } \\
\text { how it fits into my class"- Alex }\end{array}$ & & \\
\hline No money for substitutes & Parental Influences & & \\
\hline $\begin{array}{l}\text { "I live in Kendall and the trainings are } \\
\text { like in North Miami" }\end{array}$ & Language barriers with tech and students & & \\
\hline Principal doesn't approve PD attendance & Inclusion classrooms & & \\
\hline Taking sick days for $\mathrm{PD}$ & $\begin{array}{l}\text { "In Terra, children are better. And you know, I don't } \\
\text { mean that in a negative way. But, you know, children } \\
\text { are from a more affluent background and they have } \\
\text { technology at home, in a Title } 1 \text { school that's just not } \\
\text { realistic." - George }\end{array}$ & & \\
\hline District WiFi not working & & & \\
\hline & & & \\
\hline
\end{tabular}

Figure 3: Overview of themes, categories, and summative statement for RQ2 


\begin{tabular}{|l|l|l||}
\hline RQ3: & What do teachers perceive to facilitators to technology integration? & \\
\hline Summative Statement: & $\begin{array}{l}\text { Interestingly, when teachers spoke about the factors that facilitated technology into the classroom, they were similar to the factors that also hindered } \\
\text { technology. The circumstances around these items, typically a condition of access, determined whether they served as barriers or facilitators. } \\
\text { Teachers reported an increased access to professional development, increased Wi-Fi access, increased access to mobile devices, increased student } \\
\text { engagement, and personal motivation as factors that facilitated the use of technology in their classrooms. }\end{array}$ \\
\hline & & \\
\hline Theme 9: Systemic Agents (Facilitators) & Theme 10: Primary Environment Agents (Facilitators) & \\
\hline Conceptual Category & Conceptual Category & \\
\hline Factors outside of the teachers' control & Factors directly related to the teacher, student related or personal & \\
\hline Selection of Open Codes: & Selection of Open Codes: & $\begin{array}{l}\text { Personal knowledge of technology and how to } \\
\text { fix it }\end{array}$ \\
\hline $\begin{array}{l}\text { Increased access to professional } \\
\text { development }\end{array}$ & Better student engagement & Students have cell phones in class \\
\hline Access to mobile devices & Personal motivation & \\
\hline Access to laptops & Better student behavior & \\
\hline Access to the internet in school & More confident because of trainings & \\
\hline Wi-Fi on buses & & \\
\hline
\end{tabular}

Figure 4: Overview of themes, categories, and summative statement for RQ3 


\section{Data Considerations}

Since qualitative research can be complex but flexible, Tracy (2010) developed a teaching model for qualitative best practices. Tracy (2010) states while the framework incorporates criteria that suggest quality, it is still flexible and open. In their own qualitative study, Gordon and Patterson (2013) applied the "Big 8 Tents" (Tracy, 2010) model to their word and determined the model was, in fact, useful because the criteria are useful but not forceful nor rigid. The following best practices from Tracy (2010) were applied to the present study: worthy topic, rigor, sincerity, credibility, and significant contribution.

Worthy topic. Tracy (2010) states that worthy topics provide surprises and remove common sense assumptions. In this study, the common-sense assumption was that teachers simply do not want to integrate technology into their classrooms. When researchers just confirm common assumptions, the research itself is not considered to be credible (Tracy, 2010). The surprise finding was that teachers in this study selected which groups of students they would be using technology with depending on the teacher perception of the students.

Rigor. A study is considered rigorous depending on the data collection and analysis process the researcher has taken. In closely abiding by the strategies outlined by Charmaz (2006), this study embodies rigor. Data points were relevant to the study, there were different perspectives being explored, and a final member-checking in the last interview 
was conducted to ensure the accuracy of the participant's perspective. This, in combination with initial and focused coding strategies, ensured richness and rigor.

Sincerity. A study is considered to be sincere when the researcher has explicitly stated his or her own bias, vulnerability, honesty, and has engaged in a data auditing process. In order to ensure honesty throughout this study, a detailed paper trail was maintained and provided upon request. This paper trail included original interviews, transcriptions, data analysis processes as well as a complete explanation of code construction and final theory construction. Additionally, my dual role as an Instructional Designer working with technology, and a college-level instructor, may create an underlying bias.

Credibility. Credibility in qualitative research can be achieved through the triangulation of data to ensure accuracy. This particular research study used participant triangulation and was executed in the various ways. Initial interview with in-service social studies teachers. There were standardized open-ended interview protocol used to ensure that all participants were asked the same question. A follow-up interview with the in-service teachers to verify if the analysis of the interview aligned with the experiences of the participant and if any clarification is necessary from the researcher after the interview. Careful review of the transcripts and audio to ensure the accuracy of the data.

Significant contribution. This study has a significant contribution to the field because digital convergence plans are being launched on a national level, and although the tangible resources are being put into place for schools, there may additional levels of support that are missing. In order for all students to have access to learning technologies, teachers must be willing and able to adapt to new teaching styles and strategies. Secondly, 
this study directly adds to the literature by the emergence of a fourth barrier. Currently, there are three published barriers to technology integration. These are Ertmer's (1999) first and second order barriers and Tsai and Chai's (2012) third order barrier. 


\section{CHAPTER IV}

\section{FINDINGS}

I began this study with the intention of identifying how social studies teachers were using technology in their classrooms. I also wanted to explore what were the barriers or facilitators to their eventual integration or lack thereof. I asked three main research questions. These questions would guide the study. These questions were:

1. How are social studies teachers using technology in the classroom?

2. What do social studies teachers perceive to be barriers to integrating technology?

3. What do social studies teachers perceive to be facilitators to integrating technology?

I will report the findings of the study conducted in Chapter 4. For organizational purposes, I will present the findings for each question separately. I will also introduce the themes that emerged from the research and provide supporting data for each theme.

\section{RQ 1: How are social studies teachers using technology in the classroom?}

The data used to answer this question derived from conducting 14 semi-structured interviews via the Zoom๑ application. Additional interviews were not conducted because saturation had been reached.

Here is a flowchart representing the research question and all the emerging themes: 


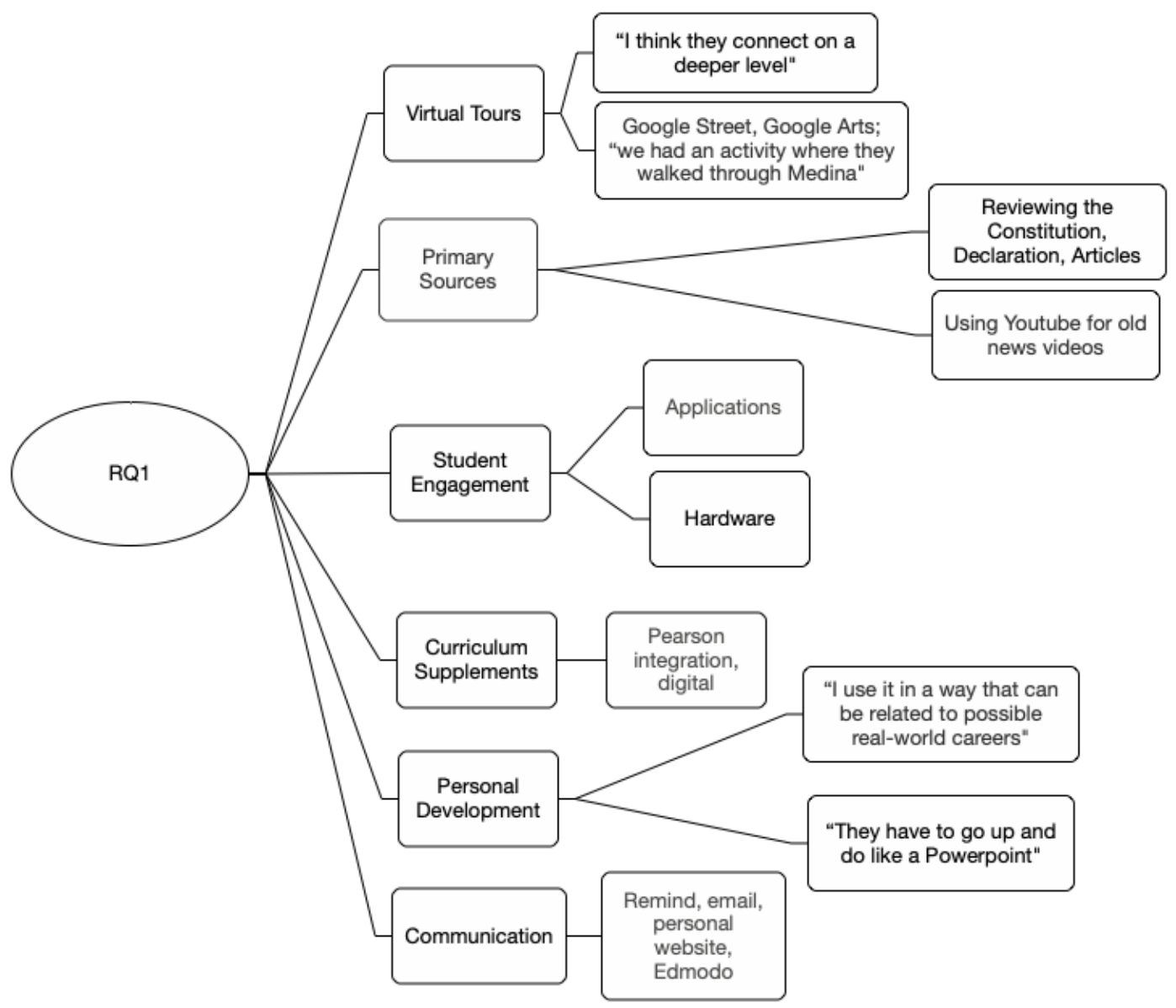

Figure 5: Flowchart representing how social studies teachers are using technology in the classroom?

For this first question participants discussed how they used different software and hardware in their classrooms. The most common responses were: PowerPoints for lectures; Google applications for visiting other countries; search engines for identifying and reviewing primary sources; free applications for creating blogs, webpages, and memes; and email for communication. Their responses were eventually categorized into 6 main themes: virtual tours, primary sources, student engagement, curriculum supplements, student-personal development, and communication. 
Virtual tours. In my study, teachers reported using virtual tours as an alternative to reading from the textbook. During the interview, Albert (all participants are being referred to by their pseudonym) stated, "I think they connect on a deeper level, you know when I cover India or China". Albert was referencing the difference between using textbooks and researching different geographical locations on the internet. George said, "I really like taking students on these, like, virtual field trips. It helps them put things together and they get that Ah-Ha moment!” Albert felt that covering the information straight from the textbook did not allow students the opportunity to see these other countries multidimensionally. The images from the textbook are "flat and still pictures", he said. Using applications like Google Street View and Google Arts, students are able to zoom into the images and identify small details and the intricacies of these spaces. Albert continued explaining,

Look handing out documents is always easier. Giving a printout or having them flip to a page is easier, but if you teach social studies these tools are amazing. It's like amazing how you can do a walk-through of the city streets and museums. You can even visit the ancient tombs and see the pyramids.

The use of virtual tours is more than just "seeing" what other places look like

versus reading about them. It is about trying to give all students the opportunity to experience the world. As Sandra stated, "not all of these kids either get to or have any interest in visiting government museums, so I try to go on the websites where they do tours online and they really seem to like it." This is especially true for students whom teachers perceive will not have the chance to experience these places otherwise. Albert continued to express how impactful being able to virtually visit other places could be saying, "they got to explore Medina. You know what I mean? Coming from a Title I school most of these children will never even leave Miami." 
For Albert, the virtual tour is a move towards establishing equity. This was evident when he said, “They most likely won't leave the United States either. So, it's not fair you know, it's not fair, so I take them to the Taj Mahal. Even if it's just zooming in, but at least they can see what real marble looks like." Without the use of applications such as Google Street and Google Maps, teachers like Albert would be limited to using the flat, one-dimensional images of their textbooks.

Primary sources. Teachers also described how they used digital primary resources in their classrooms. For example, George a high school level social studies teacher said, "It's easier for me to give them a document or handout, but I prefer they go to the actual source". Sandra, who also teaches social studies in high school, said that throughout the year students will have a project due on the Articles of Confederation and the Bill of Rights. She said,

The students have to go through the media. They have to go to center websites and visit the online databases to find their sources and part of that is done in class. We also watch the news every day. We watch CNN Student News. When they heard about Cathy Giffords, I was able to go onto YouTube and find the original news reporting and say, Look - Here she is.

Although Sandra did not expand on why she felt it was important to discuss Gaby Giffords (a politician who was a victim of gun violence, referred by Sandra as Cathy Giffords) to her students who, she did state access to the internet and old YouTube videos helped the students better understand the political climate at the time. Sandra acknowledged that she felt students did in fact understand the content better. George said by going to the actual source he has noticed that "students can better engage with the content and hopefully think more critically, ask more questions, and be intrinsically 
motivated to continue to do more research. I want them asking me questions that I didn't think of." Three of the teachers, Albert, George, and Sandra, stated that although it is more time consuming, using the primary sources helps the students learn and retain the content better. Sandra said,

It's important for me for them to find the information on their own, and to use those primary sources, especially from the government sites, because I think they learn it better. Maybe you have heard of this, but there's like a saying that goes we retain maybe $10 \%$ of what you hear and like this percent of what you see, but the most learning happens when they can do things. They retain like $80 \%$ just by doing things. So instead of lecturing to them all the time, I create projects for them to do. It's not just regular projects, it's projects that makes them go out and review those primary sources. Like, they have to learn where to find it.

For Alex, the use of digital primary sources also helped to manage student behavior. During his interview, he said that having students use their hands and fingers to Google these primary sources helped alleviate some of the agitation or fidgeting they had. It served as a distraction. He said, "I have them look up the constitution, read that, look up the articles, read that, I have them look up policies and read that... and the questions I get from them are awesome. They stay on track cause they got lost in like this web of googling things, It's like two birds with one stone."

Aside from just using the internet to have students search for items, teachers also reported using primary sources in the form of old news videos - typically found via a YouTube search. Teachers play archived news videos for students, and then they discuss as a group. Alex says he uses videos as his bell-ringer activity.

I like to watch CNN10 with my students. CNN10 does a good job at staying objective and I've never really had a problem with how they report things. The kids watch the news and video reports, then they have to write up a summary about it. Depending on the conversation, we may sidetrack a little and start to look up more information on what we just saw. But I like to do fun things also, so I 
like to YouTube the old SNL headline clips. The news is reported in a funny way and it gets the conversation started. Then we search YouTube for the more serious versions of the news.

Ana does a similar thing in her classes. She said:

I encourage my students to look up old presidential debates or it's always really cool when they see what was considered breaking news in relation to a political situation - like the Bill Clinton impeachment or the O.J. Simpson trial. They read all these things about it, but when they see it, it really does take them a few minutes to process it in their heads. It is really cool.

Student engagement. All of the teachers reported how they used technology in their social studies to try to captivate students' attention and increase student engagement. The teachers discussed different types of strategies they used to help increase student engagement. Therefore, this theme was further categorized into hardware and software.

Hardware. For the purpose of this study, hardware will refer to the tangible and physical components of technology. These can be tablets, laptops, computers, cell phones, Smart Boards, etc. In regard to hardware, teachers reported using the following: mobile devices (including tablets and cell phones), computers (laptops and desktops), Smart Boards, and a traditional overhead projector. It is interesting to note that although all teachers in Miami Dade should have access to a Smart Board, only two teachers reported actually having access to the them but "not really" using them, because they did not use them in a way that increased student engagement. As Sandra said:

You know, we do have a Smart Board. But when the Smart Boards came in it was just like, here you go - have fun. We didn't get enough training on it, At least I didn't get enough training on it. So yea, I use it, but I use it really to search the internet. It's just a large computer screen. I don't see how it helps engage my students, but I guess I just don't really know how to use it. 
In regard to his Smartcard, Jorge said, "First, my Smart Board never works and is always getting stuck. Second, the kids want to do things on their own screens, not on mine. Maybe if I taught Math or Science it would be more useful but not for my class now." Not all of the teachers felt this way though, Alex, a middle school social studies teacher said that he likes to use his Smart Board. "I find it extremely helpful, when it works, Especially for geography. They can come up and point to the states and we make a game out of it. The kids like it because it's competitive and stuff, " he said. The teachers who did not find the Smart Boards to be useful were high school teachers and the teacher who did find it useful worked with the lower levels (sixth to eighth grade).

Additionally, teachers stated that students are permitted to either bring in their own devices from home (personal cell phones, tablets, or laptops) or they can use the ones provided to them by the school. Six of the seven teachers interviewed stated they allowed students to use their personal devices, such as cell phones, laptops, or tablets, to access the internet and participate in synchronous gaming. "I let them use their own phones to Google things or search for things. I have never had a problem with a student not having phones, these are seniors. But in case they don't I guess they can use the classroom computer or the computer lab," reported Jorge. Albert said, "I tell the kids, ok guys we are going to do a Kahoot!®, Take out your phones. And you don't have to tell them twice. In that sense, having access to cell phones has really been helpful." One interesting note is that two teachers reported they prefer to use the hardware for students to engage with the material but not necessarily use it to complete assignments. These teachers were concerned that student penmanship would be affected by not practicing 
their writing and so they opted for assignments that require students to practice their handwriting. Alex said, “it's scary to see that they don't really know how to write, so I try to keep a balance between tech and non-tech." For example, if students had to submit a reflection after watching a video, the reflection is handwritten.

Alex said that with his middle school students, he doesn't really use the projector for its traditional purpose such as displaying information on a wider screen or posting lecture notes up for the class. Instead, he uses it as a substitute for higher-tech equipment. The projector is used as part of an Escape Room that he builds for students. He states, "the students are like, whoa, like you just did all this and I'm like yes, pretty much. And it only takes me 10 minutes. I set it up so fast, it's really not that bad." He says that because of his knowledge base in information technology he can see hardware as dynamic tools and gets creative in his classroom.

Software. The teachers interviewed reported many different types of uses for software in the classroom. For the purpose of this study, the term software will refer to web and non-web based applications and programs, including word processing programs and internet search engines. Table 4 represents the different types of software and purposes reported by teachers: 
Table 4

Overview of uses of technology in the classroom

\begin{tabular}{|c|c|}
\hline $\begin{array}{l}\text { No Internet Connectivity } \\
\text { Needed }\end{array}$ & Web-Based Applications \\
\hline $\begin{array}{ll}\text { - } & \text { Microsoft Word } \\
\text { - } & \text { PowerPoint } \\
\text { - } & \text { Excel }\end{array}$ & 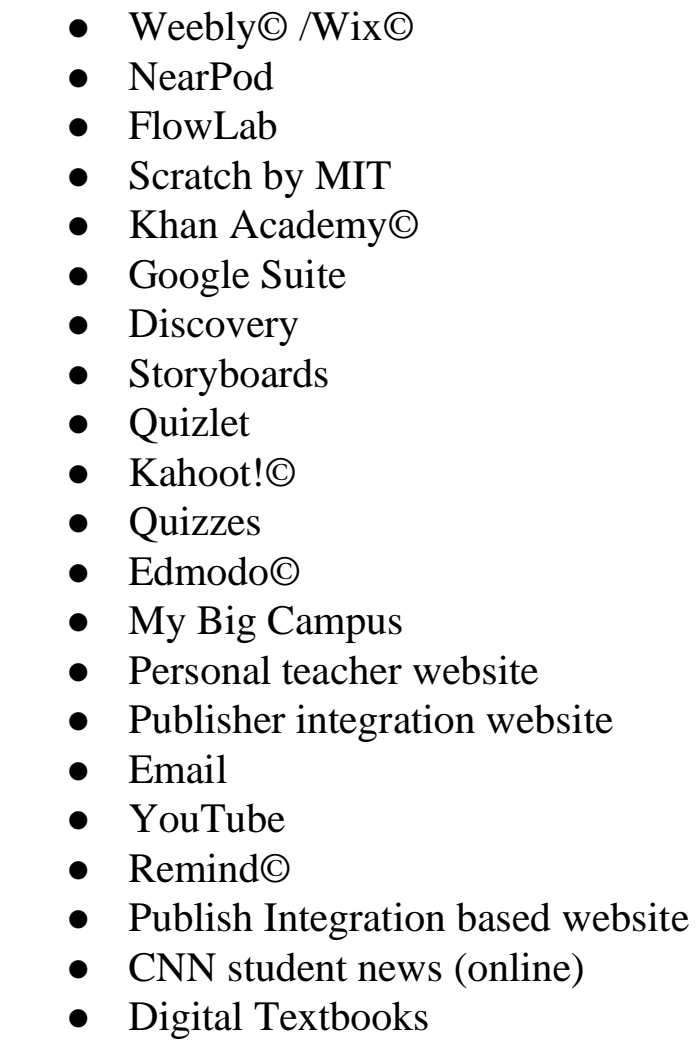 \\
\hline \multicolumn{2}{|l|}{ Purpose: } \\
\hline \multicolumn{2}{|c|}{$\begin{array}{ll}\text { - } & \text { Personal website } \\
\text { - } & \text { Content creation } \\
\text { - } & \text { Coding } \\
\text { - } & \text { Curriculum development } \\
\text { - } & \text { Research } \\
\text { - } & \text { Gamification } \\
\text { - } & \text { Assessment } \\
\text { - } & \text { Content sharing } \\
\text { - } & \text { Communication } \\
\text { - } & \text { Curriculum enhancement }\end{array}$} \\
\hline
\end{tabular}

Note: Table describing different types of software reportedly used by teachers in the classroom. 
Teachers discussed how not all applications require internet access. For example, Microsoft Word, Excel and PowerPoint are applications that do not require students to access the internet. Their use in the classroom can be fully functional regardless of the internet connectivity in the classroom is not stable nor available. Teachers reported using PowerPoint as a way to store and present classroom lectures. All teachers reported they use PowerPoint, and more than half of the teachers reported using PowerPoint because it is what students have to come to expect.

Other types of applications that require internet connectivity were mentioned by the teachers. Aside from using personal websites, teachers used applications that would specifically put students in control of their learning. For example, all teachers reported using the application Kahoot!@ in their classroom. Kahoot!@ is a registered trademark and a game-based application for quickly assessing content retention and surveying the class. All of the teachers interviewed who reported using Kahoot!@ had their students create the questions. The teachers like Kahoot!@ for its unique ability to make students part of the teaching team by being responsible for creating questions for their peers and assessing each other. As Albert stated:

It's not only playing a game. It's the music and the data. All of it. They are having a wonderful time, but hey, I'm looking at the content you know. I tell them, you guys aren't being rigorous enough with that question, for example. I don't know how to do a Kahoot!@ myself, but the kids know, and if I ever need to do one they will be the ones teaching me.

Another application that was commonly mentioned was Edmodo $\odot$.Edmodo@ is

a free platform that gives teachers the ability to share lessons, send messages, store content, and communicate with parents. Five out of the seven teachers reported using Edmodo $\odot$ regularly. Albert said, "It's like social media but you can transmit 
PowerPoints. You can keep a library, you could make it interactive.” Alex, Christy, Albert, Ana, and Sandra said they like to use Edmodo $\odot$ because students can access it through their phones and access either content for the class or communicate directly with their teachers. In fact, Alex said that what he likes the most about Edmodo® is "that way there is no exchange of personal information and I don't have to give students my phone number to communicate with them." The teachers reported that students like Edmodo $\odot$ because it has a social media feel, similar to Facebook, and that is something they are already familiar with. Although using the PowerPoints does not require internet connectivity, in some cases actually accessing the PowerPoints do. For example, Sandra indicated that she stores all her PowerPoints online for her students. She said the district has provided all teachers with the ability to create a personal website they can share with their students, and she chooses to share the PowerPoints with students on the website, so they can have continuous access to it. She said:

I was so happy when someone told me that I could set up my own website and use it to store my PowerPoints. All you have to do is navigate to the school's webpage and you search for me. My website comes up. I show the kids how to do it on the first day of school. They catch on quick. After that, there really is no excuse for not being prepared.

Ana was very excited that her school was recently promoting was NearPod. She stated, "I do a lot of different things with technology in the classroom. One of the ones the district is finally on board with is NearPod. My students love NearPod. It's a great way to really get them interested in the lessons." This teacher also tries to engage students in other ways. For example, she said, "sometimes we create memes based on historical figures. It's like our modern-day political cartoons. My students also get to 
create websites and mobile apps for their research projects.” Although Ana likes to use these applications, they require internet and as she, George, and Sandra stated, the internet was not always so reliable.

Non-internet based applications such as Microsoft Word, PowerPoint, and Excel, were used by teachers as back-up assignments. For example, Alex said:

it only takes you getting burned by technology not working one time before you realize that you have to be prepared with back up lessons. My backup lessons usually consist of a PowerPoint, cause that will always work. I don't need the internet.

Sandra shared this sentiment by saying, "I have a PowerPoint for every lesson, just in case something happens and I can't log onto the internet." It is interesting to note that although PowerPoint and Microsoft Word are considered technology (software), the teachers interviewed did not consider these advanced pieces of technology because it required the teacher to lecture and did not actively engage students. When the teachers spoke about PowerPoints, Sandra, George, and Alex, said that because students were expected to sit and take notes during a PowerPoint lecture, they really did not consider that to be "technology-technology", As George phrased it. George, Sandra, and Alex only considered advanced technologies to be either software or hardware in which students were primarily in control of manipulating and using, not components in which were mostly teacher-driven.

Curriculum supplements. The county moving towards digital textbooks has opened the door for teachers to incorporate technology on a more regular basis. As Ana stated in her interview: 
Since the county now has moved to digital textbooks, it's really a 50/50 on how we decide to use technology. On the one hand, we have to use but on the other hand, we can decide what else we want to incorporate.

George stated, "We have a partnership with Pearson, it's a company that publishes textbooks, and so they have a lot of resources online for their textbooks." He continued to say that teachers have a choice to use the additional integrations, but do not really have a choice in the digital textbooks.

As an alternative to the digital textbooks provided by the county, some teachers are moving towards free open education resources, such as Khan Academy@ . Five out of the seven teachers mentioned they use Khan Academy® in their classrooms. Khan Academy@ offers free resources for teachers in all subject areas. The website not only provides supplemental content, but also, full lesson plans, assessments, and assignment ideas. Albert spoke at length about how incorporating Khan Academy@ into his Advanced Placement (A.P.) class has helped the students learn the content better. He said, "I use Khan Academy(C) extensively. We use it to review content and I know can track how much time they spend on it. I can use it as an Independent Studies." He continued by explaining that incorporating technology into A.P. courses was difficult because A.P. is taught using the Socratic method and he could find little room for technology integration. With Khan Academy@ , it was different since Khan Academy@ offered so much flexibility in how he and the students could access the content and lessons.

Personal development. During the interviews teachers stated they wanted to incorporate technology into their classrooms because they found that using technology 
helped children develop personally as well as academically. For example, Ana said, "I use it in a way that can be related to possible real-world careers. Like if you're interested in being a web developer, you can create a website. So we may use something like Wix@ or Weebly(C)." Albert said he uses technology to help bring children out of their shell. $\mathrm{He}$ said, "I make them use PowerPoint. That way they have to read the material, prepare a presentation, and get up there and present. They can't be shy. There is no time for being shy." Albert continued his thought by saying that we are preparing students for the workforce and they have to get practice. By him asking his students to present their reports in creative and interesting ways, he felt he was doing his part in preparing them for their future - especially job interviews.

Communication. Finally, all teachers reported using technology for direct and indirect communication. Specific applications such as Remind $\odot$, Edmodo $\odot$, and Schoology were among the most commonly mentioned. For example, Alex. stated, "I have communication apps like Remind $\odot$ that I'm using to constantly send online reminders." Albert said:

In this day and age I am hesitant to give students any personal information and using something like Edmodo $\odot$ helps. I never give them my personal phone number. I can also use it as a way to keep in touch with parents and the kids' parents can see how I communicate with their children. It's all right there, in black and white.

He also mentioned that Edmodo $\odot$ was helpful because if he misses a day of class or if students miss a day, he can send quick messages back and forth.

Ana discussed how taking advantage of the district's portal has helped her to be better able to communicate with her students. She said:

I can leave messages for my students right there or they can send me messages, It's great. I don't have to shuffle through papers to find an email address or write 
myself a note to tell the student something the next time I see them. And if they're absent - forget it. I'll forget.

Christy had similar sentiments but with the Remind $(\mathcal{C}$ application. She said:

I remind them about any upcoming tests or major assignments, especially on the weekends, because they want to go out and hang out with their friends and forget about their homework. That way they can't tell me that they forgot. I reminded you.

Albert shared this sentiment, by saying "these kids always want to be out with their friends and hang out. They aren't thinking about homework over the weekend. So I remind them. I don't necessarily like reminding them, but it's what they are used to." He said he likes the fact he can use these applications to put the responsibility back onto the student.

Although most teachers who were interviewed used either Edmodo@ or Schoology, one teacher did mention an application called, "My Big Campus". He said it was similar to a learning management system like Blackboard@ his content and notes for students, and they can access it at their convenience. This platform allows all information to be stored in one place, creating an ease of accessing content for students.

Finally, Sandra discussed how she used Skype with her students. She discussed how due to a medical issue she was not able to return to school until she received medical clearance from her doctor, but that the students were still responsible for learning certain benchmarks because it was an advanced placement course. She said, "I had one medical issue after another. It was pneumonia and then my blood pressure. I was out for a while. And I said to myself, well, I guess I can Skype them, and so I did," She was able to effectively communicate with students what they needed to do and her expectations by 
using the Skype application. She said, that if that were not an option, she did not know how she would have gotten it done.

\section{RQ 2: What do social studies teachers perceive to be barriers to technology integration?}

In an attempt to answer this question, teachers were asked to discuss the different circumstances in which they felt were preventing them from really moving forward with the integration of technology into their classroom. After coding each interview in its entirety and constantly comparing data against each other, I ultimately concluded that there were two emerging themes. These were: Systemic Agents and Primary Environment Agents. The chart below represents the two areas. 


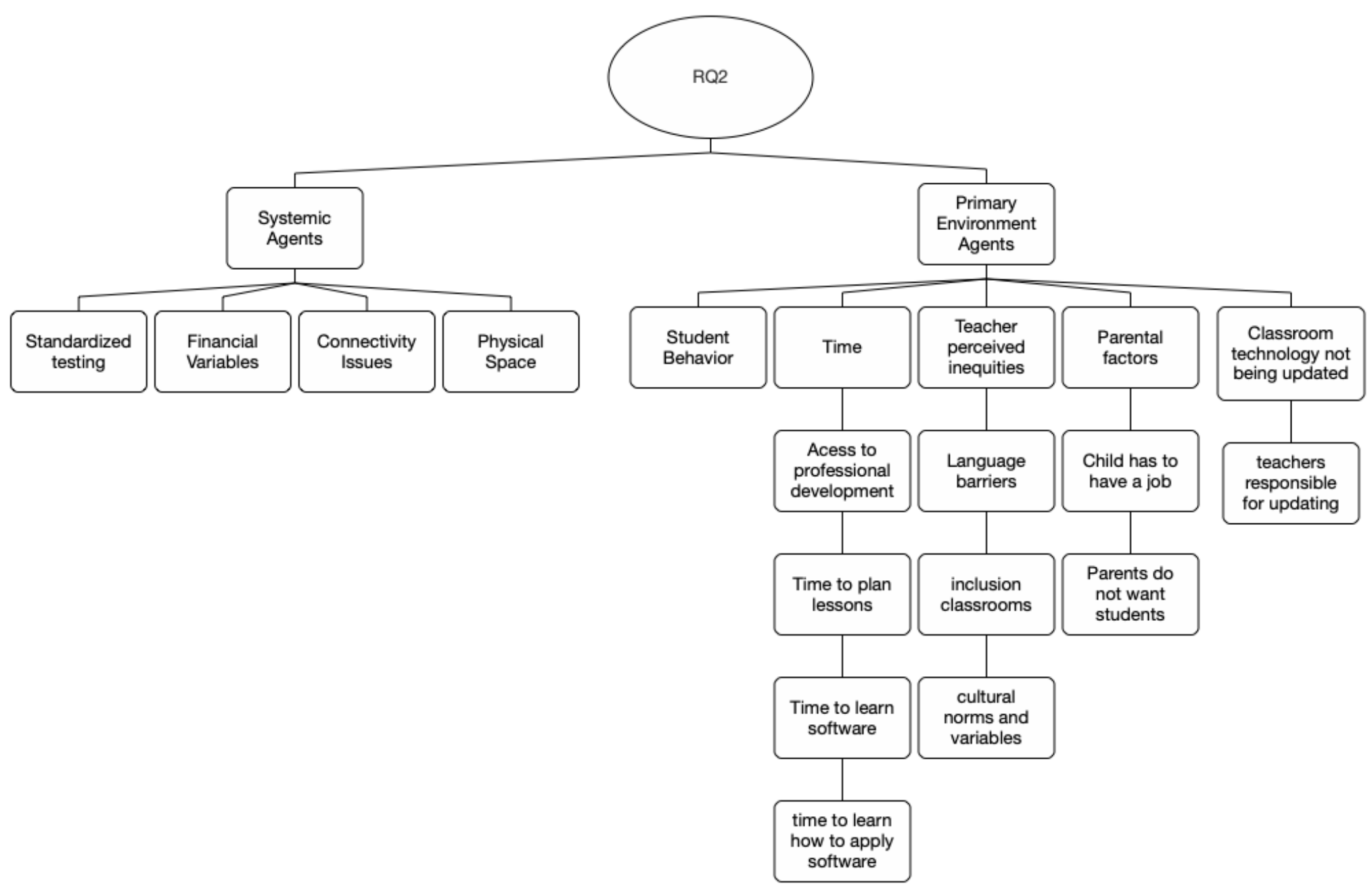


Figure 6: Flowchart representing what teachers perceive to be barriers to technology integration.

As Figure 6 reflects, there are two overarching themes, incorporated smaller emerging themes. I chose to label factors outside of the classroom that impede teachers from integrating technology into their classrooms as systemic because systemic means "relating to a system, especially as opposed to a particular part" (Merriam-Webster, 2019). The public school is only one part of a larger system.

The classroom is not completely a silo. The classroom is part of a greater entity, a larger and more dynamic unit of decision-makers and stakeholders. Although teachers have some flexibility with how their classroom functions, ultimately there are external factors that may impede them from moving forward. The interviews in this study identified the following external factors that impede the use of technology in the classroom: standardized testing (e.g., end of course exams), financial aspects, and internet connectivity issues. The environmental factors include student behavior, time, teacher perceived inequities, parental factors, technology, and physical space.

\section{Systemic Agents}

Standardized testing. When interviewing teachers about the technology integration into their classrooms, the end of course exams and standardized testing came up frequently. The decision as to whether to incorporate technology into the course curriculum or not was highly dependent on state-level expectations. As George said:

'I'm lucky because I also get to teach World History. It's not that intense because I have flexibility. But if you are in one of those EOC classes like American History or Civics, look you gotta be done with your material by the second week of April. You can't. You don't have time to add new technology." 
He continued by saying "there are certain prescribed guidelines that you have to do" in regard to preparing the students for their end of course exams, "and at some point, you have to make a decision, are you going to spend your time trying to use technology or are you going to spend your time using what you know already works?” Albert confirmed this sentiment by saying that the requirements of the EOC exams and statelevel testing detract from integrating technology into the course because students' scores on the exam are related to a teacher's evaluation and contract renewal. George continued saying, "Does it really make sense? Am I going to take that chance? Am I going to go the route I know or am I going to try something new if this is tied to my evaluation?" Interestingly, the teachers interviewed ranged from teaching students in the sixth grade all the way to high school seniors. The standardized testing and end of course exams were a barrier to technology integration for all of them. Sandra said:

Honestly, I hate that I even have to say this, but this whole teaching to the test thing is real. I have to do it. We have an end of course exams. It's a statemandated test. Then, my kids have college boards. So, as far as my teaching, it's just something that I have to do.

College boards are exams that students have to take at the end of the course in order to gain college-level credits for the course.

Financial aspects. Financial aspects in regard to this specific study really focused on money being available for teachers to attend professional development trainings. Several teachers reported that in order for them to be able to attend a professional development training the school needs to be responsible for finding a substitute. If the training being offered does not offer a stipend for substitutes, the teachers reportedly are 
asked to take a sick day by the principal. Some teachers are not willing to do this. For example, George said:

It really depends on the relationship you have with the principal. If they don't see a value in the training they put in a situation that it's like, they don't deny you going to the training, but they ask you to take a sick day or personal time and they say it's because there is no money for a substitute.

Ana reported similar sentiments when she said:

One of the main factors for me that is making using technology in the classroom difficult is that I just can't use all my personal days for professional development and getting sub-coverage is very, very difficult. Even though a lot of the trainings say there is a stipend for professional development somehow when we ask there is no money. So as much as I would love to go to the trainings I can't use all my days just for that. And it sucks because this actually has nothing to do with technology. I just can't go.

The teachers interviewed were confused as to why they were being told there was no money for substitutes when weekly briefings provided by the county specifically mentioned that substitute stipends were available.

Aside from substitute coverage for attending training, another characteristic that emerged from data in regard to finances was the maintenance of the equipment. For example, one teacher reported that he has twenty laptops and fifteen chargers and that the school will not give any more chargers. "It's really hard for me to have my computers running up to date and fully charged," said Alex. Therefore, in order for him to have the laptops ready for his students to use he has to arrive for work early and ensure that all his laptops are charged. He stated that if the school were to replace the missing chargers then he would be able to use the laptops more often, but that getting to school early every morning was something that he just could not do. He also reported that the school did not 
have money to buy laptops for every student, so teachers were also asking him to borrow his laptops and sometimes he got them back on time and sometimes he did not. He said, "It is very frustrating. I sometimes spend all of my planning period just getting laptops ready just for another teacher to come and ask for them." Luckily for Alex, he has the technical background in order to install updates and repair minor issues with the laptops himself, otherwise, he said that waiting for the Information Technology (IT) Team to fix it would set him back even further.

Internet connectivity. Internet connectivity was also widely mentioned by teachers as being one of the barriers that prevented them from integrating technology in the classroom. Ana said, "If I had to really say that there is one thing that really locks me up when using technology, I would have to say that it's the internet. It just never works." Sandra reported during her interview that she was trying to get students to do a Kahoot!॰ game and they were moving around the room for almost fifteen minutes just trying to get a solid signal. She said that at one point she almost told the kids to forget it and use paper and pencil. She said, "we have an old building and it used to be a hurricane shelter, so getting signal in here is really hard." If a teacher is attempting to stay on track with the pacing guides or the lesson plans and wants to take the initiative to use technology in their classroom the lack of a consistent internet signal has indicated to be sufficient reason to keep this particular group of teachers from really embedding technology into their lessons. George said, "Like today, for example, we haven't had Wi-Fi. So even if you had the activity planned or if you had a digital classroom you wouldn't have been able to do it because the Wi-Fi has been out for the whole district. Actually, for the last two days. And you never find out why it didn't work." Teachers expressed this as being a 
point of frustration because using technology is being mandated by the district and it appears on annual evaluations, yet, as one teacher stated, "there is no line next to the checkmark that says, 'internet wasn't working'".

\section{Primary Environment Agents}

Primary environment agents for this study include characteristics that are directly related to a specific student body and learning environment. I opted to name this as such because I noticed that the way teachers incorporated technology was heavily dependent on the space and culture-specific to each class. In one of his/her classes, the teacher may have all factors align in a way where he/she feels they can integrate technology effectively, and in another class, they may the integration may hinder time on task. Six themes emerged from the data in regard to agents that acted as a barrier for technology integration. These were: student behavior, time, teacher perceived inequities, parental factors, technology not being kept up to date, and physical space. An explanation of each follows.

Student behavior. Teachers reported that student behavior was a major factor in whether or not they opted to use technology with a specific class. Examples of student behavior that prevented teachers from using technology included students who required much attention to get on task and remain on task. For example, teachers reported classes which historically require a lot of redirection are classes where technology use is low. One teacher who was interviewed questioned if he already had a limited time with students, why was he going to spend twenty minutes redirecting behavior just so his students can use an application if that twenty minutes can be used for instruction through a lecture? In this case, the teacher indicated that using technology was somewhat of a 
reward, and they were not going to reward students with technology use if they did not behave appropriately. 'You know, I tell them, hey guys we don't have to do it this way, I can just turn the computer off and we can go right into the books. They normally complain a little, and I tell them, ok then let's get back on track." Teachers in the present study were using technology as a reward or punishment as an agent of behavioral control George reported this when he said, "in a case like this, where behaviors are all over the place, is technology use going to be positive or is it going to hinder the overall process of learning?" said the teacher. Ana, on the other hand, had a different experience, she said, "behavior management when I am using technology in the class is rarely an issue. They are doing things and involved in their work, there really is no opportunity to be misbehaving." Alex also reported that student behavior was generally positive during lessons where his students were actively using technology.

Another aspect related to student behavior that teachers focused on was how students engaged with the content. If students were not actively engaged with the software or hardware, which resulted in a significant lag in time or a lag in being able to continue with the lesson the teachers were less inclined to use it. As one teacher put it, "I basically look at the students and try to determine through their body language and behavior if what I am doing is helping them or if it's boring to them." George said, “using technology is not for everyone, sometimes some kids just can't handle it." This was not isolated to George; other teachers expressed that they feared losing control of the class and having bad behaviors begin to develop, so they carefully considered whether the technology would help or hinder their goal with each specific class. 
Time. From personal conversations with teachers, the concept of instructional time seems to be an issue. Teachers express concerns regarding how much contact time teachers have with students and how different scheduling patterns (block vs. traditional scheduling) impacts how instruction happens. This study was no different. All of the teachers interviewed reported a lack of time as being one of the main reasons why they do not engage more with technology in their classrooms. Time was categorized as: time in relation to lesson planning, time in relation to research, and time in relation to execution.

Teachers reported that planning for technology was more than just planning a lesson with a new tool or application. It was about planning the lesson, planning the time to model how to use the tool or application, and creating a backup lesson (equally engaging) in case the technology failed. George said:

Saying that I'm going to use technology is a big deal. Technology can be adjusted, and I have to have the time to figure out how I'm going to adjust my instruction to the technology. Because, look, if you have a class with 10 inclusion kids and 10 regular kids, you have to spend like 20 minutes of your class time waiting for those inclusion kids to catch up. I just don't have the time to do it. I wish I did.

George said he simply just did not have the time to do all this planning and admitted to forgoing technology because there was just no time to plan. On the contrary, Ana said that taking the time to teach students how to use the technology was just "growing pains." I don't see investing time to teach how to use the software or a tablet as a loss of instructional time because it's going to pay off at the end. I ask myself, do I want to take the time to teach them how to use it now so we can have a better school year or am I going to just revert to what I already know how to do? It's a fair question and I 
normally decide to go forward with the technology." Alex expressed his frustration with time was when the computer restarted on him mid-lesson. "I remember when we were taking an assessment and it was like all the computers decided to just shut down and restart right there. Yea, I would definitely say I got burned that time, and I kept thinking how much time we were wasting." As per the interviews, teachers had to negotiate many factors when determining how and if time was going to be allocated to teaching with technology and tried to determine if learning and using the technologies in their classrooms was worth what they perceived to be time lost for instruction.

Teachers also reported that before any hardware or software can be used in the classroom, they need to determine if it is appropriate for the classroom and how the technology interacts with the content. Alex said before he used anything in his class, he had to do a test run with it and see if it really was the best application for the content he is teaching. He admitted that this takes a lot of time and he normally does this over the weekend or during a planning period. Christy reported that if she cannot adequately research the tool or research how it was going to benefit her students, it would actually delay from integrating technology into the classroom. She later stated that because this was the case, although she uses technology it is typically low-level like a PowerPoint or a quiz game.

Finally, teachers reported that incorporating something new into the classroom took time for the students to learn and that detracted from the lesson of the day. "Students at times are already struggling with the content, now add onto it that they need to learn something new on how to get to that content. It can become a bit messy." Teachers also expressed hesitation in incorporating new technologies because if they did not work, and 
the teacher themselves were not familiar with it, it would take time to learn how to troubleshoot the problem in order to get everyone back on track. As another teacher reported, "I am just wasting time trying to figure this thing out and at some point, I just have to throw my hands in the air and say guys, 'his isn't working.' Then what? How much time did we just waste?"

Teacher perceived inequities. While coding the participant transcripts, I started to see a theme regarding fairness or equitability in technology use and physical access. During their interviews, teachers discussed how they felt that specific circumstances actually prevented students from having the opportunity to use technology in the classroom. These circumstances included factors such as having high inclusion classrooms, the different socioeconomic levels of the students, or the technology itself not being appropriate for the culture of the school or classroom in regard to the primary languages spoken by the students.

In regard to inclusion, some teachers reported that when they had an inclusion classroom using technology that aligned with higher-level activities became more challenging. Teachers reported using more familiar technologies - like PowerPoint, Word, or Google - when their classrooms had a significant number of inclusion students. One teacher said, "Look if you have a class with 10-15 inclusion kids, are you going to spend 20 minutes of your class time waiting for these children to catch up with the others or are you just going to get to the meat and potatoes of the day?" To clarify, this teacher did not feel that inclusion students should not be using technology, but that using technology in an inclusion classroom can be challenging and potentially slow down the other students who may not need as much direct assistance. He said, "I have to teach 
everyone in that class, and so I am just going to go with the one way of teaching that is going to be straightforward and basic. I am going to do a PowerPoint and we can have conversations afterwards."

Financial inequities also came up during the interviews. Teachers who were in lower socioeconomic areas stated that using technology with the children at times was difficult because students potentially did not have devices at home. When these students had access to iPads at school all they wanted to do was play with them. One teacher said that students who were borrowing devices from the school did not even want to use them because they preferred to have an iPhone or a newer model phone. Several teachers said that students who came from more affluent schools were probably easier to work with, in regard to technology integration. George said, "In a school like Palm High, these students are better. Better in the sense they come from more affluent backgrounds and they have technology everywhere and in a Title 1 school that's just not realistic, especially when you have an inclusion class." For George, the inclusion classroom presented more of a challenge in relation to technology integration because he perceives that students who are atypical learners require more time and attention when teaching and using technology in the classroom. This is time he believes he does not have. This is different from students who do not have physical access to technology, because these students have the opportunity for physical and tangible access, if the teacher would choose to allow it.

Another area that was discussed by the teachers in regard to inequities was the relatability of the software to the students in the classroom. Teachers reported that at times they opt to not use technology because the technology application or software is too out of touch with the community in which they work. "The technology is not set up in a 
way that helps children from our area. We have students who literally do not speak a word of English and we send them all to sit in front of a computer and use a program that is all in English. That is not fair to them" said one teacher. Sandra felt that the district was making business decisions without taking into consideration the children within the district. She said:

The district just partners up with people and doesn't really ask teachers what will work for their students. They don't look at the context of the school. It's like here is McGraw Hill go ahead and implement this program, but they don't look at the implications and what those are for our students and how it fits within our school. It's just - here, try it.

Sandra was not the only interviewee who felt this way. Alex said that his students are different than the students from other schools. Because he has a high population of homeless students. He said:

Some of my students do not go home after school, they go to a shelter. I'm supposed to make them go watch a video or search the internet for information? Or ask them to type up a report? No, I'm not doing that. That's not their biggest problem right now.

Alex, like Sandra, Albert, Jorge and George, have independently decided within themselves that some their students, due to varying student circumstances, are not going to use technology in some of their classrooms. Although these teachers may feel they are helping these students, they may in fact be inadvertently hurting their academic and developmental progress.

Technology out of date. Technology is typically only useful if it works and allows the user to reach the end result in a more efficient manner. Hardware and software need to remain up-to-date in order to function properly. Teachers in this study 
reported that having to use technology that was out of date actually cost them more in regard to a loss of time than when they need to figure out how the technology actually works.

In talking with Alex, he mentioned how one of the aspects of technology that is actually a deterrent is the fact that he has to physically run updates on each computer. $\mathrm{He}$ said that can take hours to just get through a few. "I literally have to get school early just to run updates and that can take hours. I don't always get through all of them," he said. Albert said that he "won't really get into the laptops if I know I haven't' updated them in a while." Secondly, Alex mentioned how students have experienced their laptops restarting in the middle of lessons in order to run updates. He said, "when something like this happens I have to ask myself, why did I even bother. Cause when those updates start, there is no stopping them. One time this happened while I was being observed for my annual evaluation and I wanted to crawl into a hole because my whole lesson was ruined." When asked why running the updated was so important, Alex said "It slows everything down when you don't run updates and it makes programs really frustrating to use. Most of the time they just don't run right or it slows the computer or tablet down." When the technology is out of date, it also does not allow the teacher the opportunity to use higher-order level types of activities. Alex continued:

I can't have them run games or applications that use flash or java if that plugin hasn't been updated or even installed for that matter. If I'm using an older version of Firefox or Chrome, it constantly tells the kids to run the update. It ruins the flow of the class and I just say you know what guys, this isn't working today, let's open up our PowerPoint. 
With the older software and hardware, the students have less of an opportunity to interact with the technology and revert to passive learning. As Sandra stated, "when it's old I just use a PowerPoint. I don't bother, it's going to be a waste of time."

Physical space. Although it was only discussed in two interviews, the concept of access to physical space was important to include. It is important to note that teachers struggle with last-minute adjustments to their ratios and class sizes due to a lack of substitute coverage or a lack of teacher attendance, as reported. One teacher indicated in her class she simply cannot use laptops because she has 30 students and only 20 desks. The rest of the students sit along the perimeter of the classroom, sometimes in chairs but at times on the floor. Ana said, "How can I expect my students to pull out their laptops or use their tablets, when they don't even have a space for their books or notepads?” Jorge reported that at any given moment, he can have an influx of students who for one reason or another were left without a teacher and so now they have to join a different class. He said these types of accommodations impede upon his lessons for the day, especially if he is using some type of technology or tool with the students. He posed the question to me, "What am I supposed to do with that? This is a deeper conversation. This is an injustice at a much deeper level."

Parental factors. In this study, the teachers reportedly felt that parents were the determining factor between whether a student had access to the internet at home or not. Albert, George, and Sandra stated that as a direct result of the efforts put in by Miami Dade County Public Schools, students now had the opportunity to borrow hot-spot devices. A hot-spot device is a device that provides internet access using $\mathrm{Wi}-\mathrm{Fi}$ technology. These devices could have been cell phones or just singular hot-spot hub, but 
students who do not have internet access at home would still be able to complete internetbased assignments or research. This would also prevent students from having to access public places such as a restaurant, coffee shop, or library in order to just access the internet. Albert was really excited about this! When Albert found about this program, he said, "I went directly to the principal to ask if there was someone in the school who was responsible for facilitating the device access to students. If no one was in it, I want to

volunteer to run it. I told him, this is a great program, why are we not pushing this?" This was when the teacher was informed that "some parents don't want to do it because you know they don't want to be responsible for it, so it's not something that we push.” The rental of the device is free for families that are low income and qualify for free or reduced lunch, for other families, the cost is minimal. If the item is lost or damaged, the students are responsible for paying a fee. None of the teachers were aware of what that fee was.

\section{RQ 3: What do social studies teachers perceive to be facilitators to technology integration?}

Since the barriers to technology integration were investigated I felt was also appropriate to try to understand what social studies teachers perceived to be the facilitators to technology integration in their classrooms. After reviewing each and every transcript and comparing one against the other the same two emerging themes arose from the data: systemic agents and primary environmental agents. The systemic agents include professional development trainings and the Digital Convergence Plan (2013). The environmental agents include teacher's intrinsic motivation, student behavior, increased access to professional development, and student access to devices. 


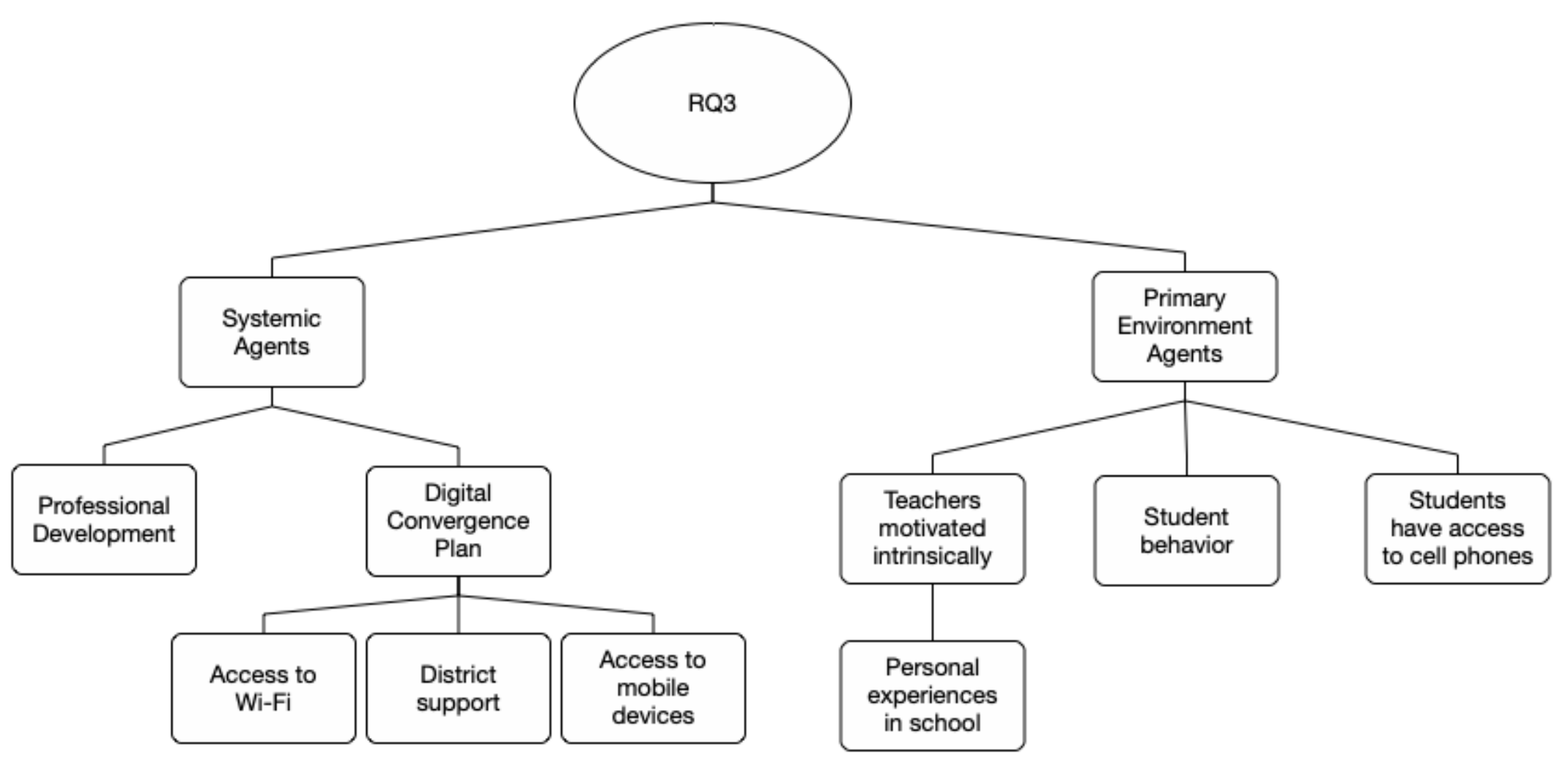


Figure 7: Flowchart representing what social studies teachers perceive to be facilitators to technology integration

\section{Systemic Agents}

Professional development. Although professional development was listed in question number two as a factor that hindered teachers from integrating technology into their classrooms, it is also a factor that has supported teachers with the digital integration. Because there is more access to professional development workshops and because the majority of the workshops do offer stipends for substitutes, teachers like Ana are able to attend more trainings. "A lot of trainings say they offer stipends to cover substitutes and that's helpful when I show it to my principal." Additionally, teachers now have more access and opportunity to be able to attend trainings offered by the district because the information regarding available trainings goes directly to the teacher now. George said, "It is pretty helpful that the district sends out a weekly briefing with the trainings and everything that's going on." He said, "You want to go the trainings because I see technology as a moving train, and you don't want to be the one that gets left behind." The teachers who were interviewed for this study reported that when they were able to attend the training the training typically proves to be very useful. For example, the teachers are engaging in hands on tasks and typically they walk away with some sort of tangible form of learning so either they created a website, or they created a lesson using near pod or maybe even it was learning how to use office 365 . As one teacher stated, "I'm walking away with something". Four teachers reported that over the last few years the quality of the trainings have gotten much better and since the trainings are now much better they are 
willing to attend more. Sandra said, "they are bringing in professionals, people who know how to use the software and how to answer our questions"

Having options on how to access trainings appeared to be convenient to five of the teachers interviewed. Aside from on-site trainings, workshops are offered online. Alex and Albert stated they had accumulated more hours than needed because the trainings are offered online. "I am supposed to do 125 hours every five years because of my teaching certificate, well, I am in my fourth year and I already have well over 300 hours. It's just so convenient to log on through the portal and see what is being offered" said Albert. Alex said, "it doesn't work for everyone, but I like that I can go to trainings on Saturdays. I think it's really cool that an option like that is even available.”. The ease of access to the trainings served as an opportunity for teachers to learn new technologies and to be able to train on their own time. This is helpful for teachers who have a hard time getting approval for off-site trainings.

Another aspect of professional development that the teachers found to be very useful, is when the trainings are able to come out to their personal classrooms and help them integrate the technology in their own environment, not just at the group training. One teacher said, "it's really helpful to have the experts come to my classroom and show me how to work with it in my classroom and outside of the group training". Albert, who is working with high school students, mentioned how he loves attending the training but more specifically the extended workshops. He discussed one in particular where the trainer showed them how to access con Academy and how to develop lesson plans that would align with the AP testing standards. He said, "once I learned how to do that there was no going back." 
District sponsored tools (Digital Convergence Plan (2013)). Most of the factors that improved the facilitation of technology into the classroom had to do with resources that were made available because of the Digital Convergence Plan (2013). Although teachers did not typically reference the Digital Convergence Plan (2013) by name, they discussed district level improvements that were made possible because of the digital convergence effort. This includes increased access to professional development, funds made available for teachers to attend trainings, increased student access to the internet, increased student access to mobile devices, increased Wi-Fi capabilities both on school buses and classrooms, updated school infrastructures, and increased Instructional Technology support by the district. This was mostly noted when teachers would reference historical versus current practices. For example, Ana said, "I remember when I would hear my colleagues talk about trainings they went to and I was like, where was I? Now, the district sends us a bulletin every week with upcoming trainings so I know what's going on."

Albert said, "With this Digital Plan thing the county started like five or six years ago, you see a big-big-big difference. Now all the kids get a tablet, and all the kids get the internet. Well, they can get it but if they do is a different story." Teachers also talked about software that was now being promoted by the district such digital publisher integrations (Ana, George, Sandra, Alex, and Jorge). Ana specifically spoke about NearPod being promoted now, and that brought her relief because she had been "using NearPod for a while." Ana was excited to share that only was the district pushing NearPod but was also providing trainings on how to use it. 


\section{Primary Environment Agents}

As mentioned earlier, the primary environment agents are factors that are specific to the teacher within a class. Depending on the classroom and the classroom culture, a single teacher may have different environmental agents that influence how and if the technology is integrated. After analyzing the interviews, the themes of intrinsic motivation student behavior and increased access to personal mobile devices emerged from the data.

Intrinsic motivation. In this study, all of the teachers interviewed attributed their integration of technology primarily on their personal interest and initiative to do so; although, the reasons behind the initiative did vary among the teachers.

Four of the teachers who were interviewed discussed their personal education experiences, specifically coming from lower socio-economic schools and how that affected their later academic years. Two teachers interviewed shared how they did not realize how disadvantaged, in terms of access and functional information, they were until they entered college. One teacher specifically said that although she was a top performer at her high school, she was shocked to see how much she did not know and how much others knew her first year of college. "I do not want that to happen to my students," she said, "so I always remain cognizant of current trends and practices, cause I want my kids to be ready." Albert mentioned a similar sentiment when he said "I love my kids. We are like a family. That's what keeps me going. And I take my job in preparing them very seriously. I don't want them to leave my class and not know how to send an attachment. They need that for work." 
Another level of intrinsic motivation that emerged from the data, was when teachers incorporated technology because it was a personal interest for them. Teachers reported their personal interest and understanding how technology can help with learning has motivated them to learn how they can incorporate it into their lessons. These teachers reportedly enjoyed searching for new applications and handing them off to the children to investigate. Albert said jokingly, "I have no idea how to use some of the things they use but as long as they don't ask me I don't tell". That participant, in particular, was not worried about telling his students he did not know how to do something. In fact, he laughed while saying that many times the students teach him, and he is perfectly ok with that. For him, it made him happy to see students engaged in activities and thinking critically about not only the content but also whatever new technology was being used.

Lastly, teachers were intrinsically motivated to use technology when the technology facilitated something for the teacher. Sandra said, "I really like the personal website the district offers. I always knew you could do a website on like Weebly or Google, but this one was easy to do and I can communicate directly with the students". For example, communication via email or an application like Remind $\odot$ is much faster and easier than approaching each student independently or waiting to see a student in class. Through an application, like Remind $\odot$, the teachers can send one message and it gets automatically pushed out to all of the students' phones or mobile devices. Creating websites to share information and house course content was also reported as being easier for teachers, instead of emailing students the PowerPoint if they missed a class or having students copy the slides during class lectures. Albert said that once he found out how Khan Academy® was able to supplement his lessons, he said, "I asked myself, what 
would I have done without this? It was so easy to use. Just click and go! I probably would have stuck to the regular old pacing guides, and now knowing what I know, that is a scary thought." The lessons and flexibility of the lessons provided to Albert on Khan Academy encouraged to continue to explore the platform and continue to use technology to enhance his classes.

Student behavior. Another major factor as to whether teachers opted to integrate technology into their classrooms or not had to do with the behavior of the students.

Teachers reported that when students were engaged, well-behaved, and the class did not require a lot of redirection they were more inclined to use higher-level technology applications with the students as opposed to just software that could facilitate a lecture, like a PowerPoint. Teachers in this study stated that in order to take a risk with the students and use more advanced types of technologies the class had to be well-behaved. This was evident when Ana said:

There are a lot of things I want to do with my students, and I try to not let their behavior get in the way of me doing so, but sometimes man, sometimes if they aren't behaving well I just can't do it.

George echoed her sentiment by saying, "Look, the technology is already new for me. If you aren't behaving and you aren't doing your part as a student in my class, how can I trust that you are going to behave while we are figuring this out together?"

Increased access to personal mobile devices. Lastly, during their interviews, Sandra, George, Christy, Jorge, and Albert reported that because students have more access to personal cell phones and mobile devices, they ask students to have their cell phones and tablets out and use them for class-related activities. One teacher said, "I 
normally ask them to Google search something quickly or to play like a Kahoot!@ I think I do this because I already know they are going to have their phones out or try to be sneaky with them, so it's like we are all grown here. I don't care if you use your phone but pay attention in my class."

\section{Conclusion}

The purpose of interviewing these teachers was to identify how social studies teachers are using technology in their classrooms and what do they perceive to be as barriers or facilitators. Teachers reported many different uses for the technology. These included taking students on virtual tours of other countries and historical civilizations, to locate and view primary sources - such as reviewing the Bills of Rights, Declaration of Independence, and the Articles of Confederation, and to enhance the curriculum through the use of digital textbooks, open education resources such as Khan Academy@, and by using publisher integration kits. Additional uses included to enhance student engagement and help students develop personally. Lastly, all teachers reported that they like to use technology to stay in contact with their students by reminding them of upcoming tasks and by making learning materials accessible to them via online portals.

In regard to what teachers perceive to be barriers or facilitators to technology integration, there were several areas of overlap. For example, professional development, student behavior, financial aspects, and connectivity issues were areas that teachers reported being both facilitators and barriers. If these areas were well addressed and accessible for teachers they served as facilitators, but if there were deficiencies in these areas then they were barriers. Finally, one of the largest barriers to technology integration in the classroom was how the teachers perceived their students and the classroom 
environment. In environments where teachers felt that students would benefit from the use of technology - it was integrated. In environments in which teachers felt it was going to hinder learning for some or all students, they opted to not integrate technology into their lessons. This decision was specific to the classroom environment and not a reflection of how the teacher felt about general technology use or integration. 


\section{CHAPTER V}

\section{DISCUSSION}

The purpose of this qualitative, constructivist grounded theory study was to find out how social studies teachers were using technology in their classrooms and what they perceived to be either barriers or facilitators to the integration. This chapter includes a discussion of the findings as they relate to the data and to prior research conducted and published. This section discusses the implications of this study has for teachers, school administrators, and district and state-level policymakers regarding how teachers are using technology in the classroom and what teachers perceive to be barriers or facilitators to the integration. This chapter concludes with a discussion around the limitations of the study and potential areas for future research.

This chapter discusses potential future implications for the following questions:

RQ1: How are social studies teachers using technology in the classroom?

RQ2: What do social studies teachers perceive to be barriers to the integration of technology in the classroom?

RQ3: What do social studies teachers perceive to be facilitators to the integration of technology in the classroom?

The social studies teachers who participated in this study discussed the ways in which they were using technology in their classrooms. In regard to the hardware being used, teachers were heavily dependent on students having access to their own mobile devices - cell phones, tablets, or laptops. According to the data from this study, when students do not have their own mobile devices, teachers experience a shortage and inconsistency of access as neighboring classrooms borrow these devices or key 
components go missing (i.e. laptop chargers). Teachers reportedly also being independently responsible for ensuring that hardware is kept up-to-date by running updates for students.

Teachers discussed the different ways in which they use software and applications in the classroom. Some of the ways technology is being used include: (a) Google Maps and Google Arts to take the students on virtual tours, (b) primary sources - the Constitution, Articles, old news sources, etc., (c) increase student engagement - students create memes, study games, collaborative work, (d) teachers enhance their current curriculum--Khan Academy@, YouTube, Pearson digital textbook integration, (e) students create and conduct presentations and explore potential real-life careers, and (f) communication between teachers and students -email, personal websites. Some of the teachers used technology to have students engage in hands-on learning activities, to research and construct their own understanding of facts, whereas others used communication mostly as an information tool - basic internet searches, facilitating lectures, and to stay in communication with students. These varying uses have different implications for learning. When students are able to use technology to construct their own knowledge, they are engaging in higher-order thinking practices (Harris and Hofer, 2011). Lower-level thinking activities typically just consist of passive learning, such as a teacher lecturing from a PowerPoint presentation with minimal student involvement.

Aside from how technology is used in the classroom, this study also uncovered barriers and facilitators to the integration of technology into the classroom. Systemic agents, such as access to professional development, the Digital Convergence Plan (2013), financial aspects, and standardized testing, and primary environment agents, such as 
student behavior, time, teacher perceived inequities, parental factors, and student access to personal devices, play a role in how teachers are going to move forward with technology integration. A systemic agent or primary environment agent may be a barrier for one teacher but a facilitator for another. The data reflects that teacher's experiences vary greatly from classroom to classroom.

\section{Interpretation of the Findings}

In 1999, Ertmer introduced two major types of barriers that teachers face when trying to integrate technology into their classrooms (Ertmer, 1999). Ertmer refers to these as first-order and second-order barriers. The first-order barriers are barriers that are external to the teacher and typically factors such as "equipment, time, training, and support" (Ertmer, 1999, p. 50). Second-order barriers are internal to the teacher and these although these are typically related to belief, the belief about "student-roles as well as their traditional classroom practices including teaching methods, organizational and management styles, and assessment procedures" (Ertmer, 1999, p.50). The findings from my study matched Ertmer's barriers and uncovered a new barrier to technology integration, teacher perception of specific groups of students. Below is a table outlining Ertmer's two barriers.

Table 5.

Overview of Ertmer's (1999) First Order and Second Order Barrier

\begin{tabular}{|l|l|}
\hline First Order & Second Order \\
\hline Extrinsic to teacher & Intrinsic to teacher \\
\hline Lack of access to technology & Self-Efficacy \\
\hline
\end{tabular}




\begin{tabular}{|l|l|}
\hline Lack of professional support & $\begin{array}{l}\text { Pedagogical beliefs - computers, } \\
\text { technology }\end{array}$ \\
\hline $\begin{array}{l}\text { Lack of time to learn and integrate new } \\
\text { technologies }\end{array}$ & $\begin{array}{l}\text { Pedagogical beliefs - classroom practices, } \\
\text { the role of the teacher or student }\end{array}$ \\
\hline
\end{tabular}

As Ertmer (1999) states, there are billions of dollars being poured into the education system in order to address some of these barriers. Miami Dade County is no different. In 2013, the Miami Dade County School Board authorized the Digital Convergence Plan (2013). The district's digital convergence has been the catalyst behind the addition of computers, laptops, tablets, mobile hotspots, internet connectivity, and teacher professional development.

Discussion of barriers.. As stated in Chapter 1, The Miami- Dade County Public School district is considered to be the fourth largest district within the United States, and in 2014 Superintendent Alberto M. Carvalho (2008-present) authorized a digital convergence plan. Through improving school and district resources, The Digital Convergence Plan (2013) intended to increase student access to technology, increase teacher self-efficacy through training and professional development, and attempt to establish equitable access to the internet at home in order to close the homework gap. This plan was intended to address areas of deficiency in regard to technology access and integration into the classroom. The main areas to be improved upon include updating schools' internet access, giving students access to digital devices, adopting digital curricula, using technology-rich schools as models for other schools, and providing teachers with sufficient training for learning how to implement technology into their classrooms (Miami-Dade County Public Schools, 2013). 
Figure 7 represents how 1 st order barriers to integration were addressed by the Digital Convergence Plan (2013):

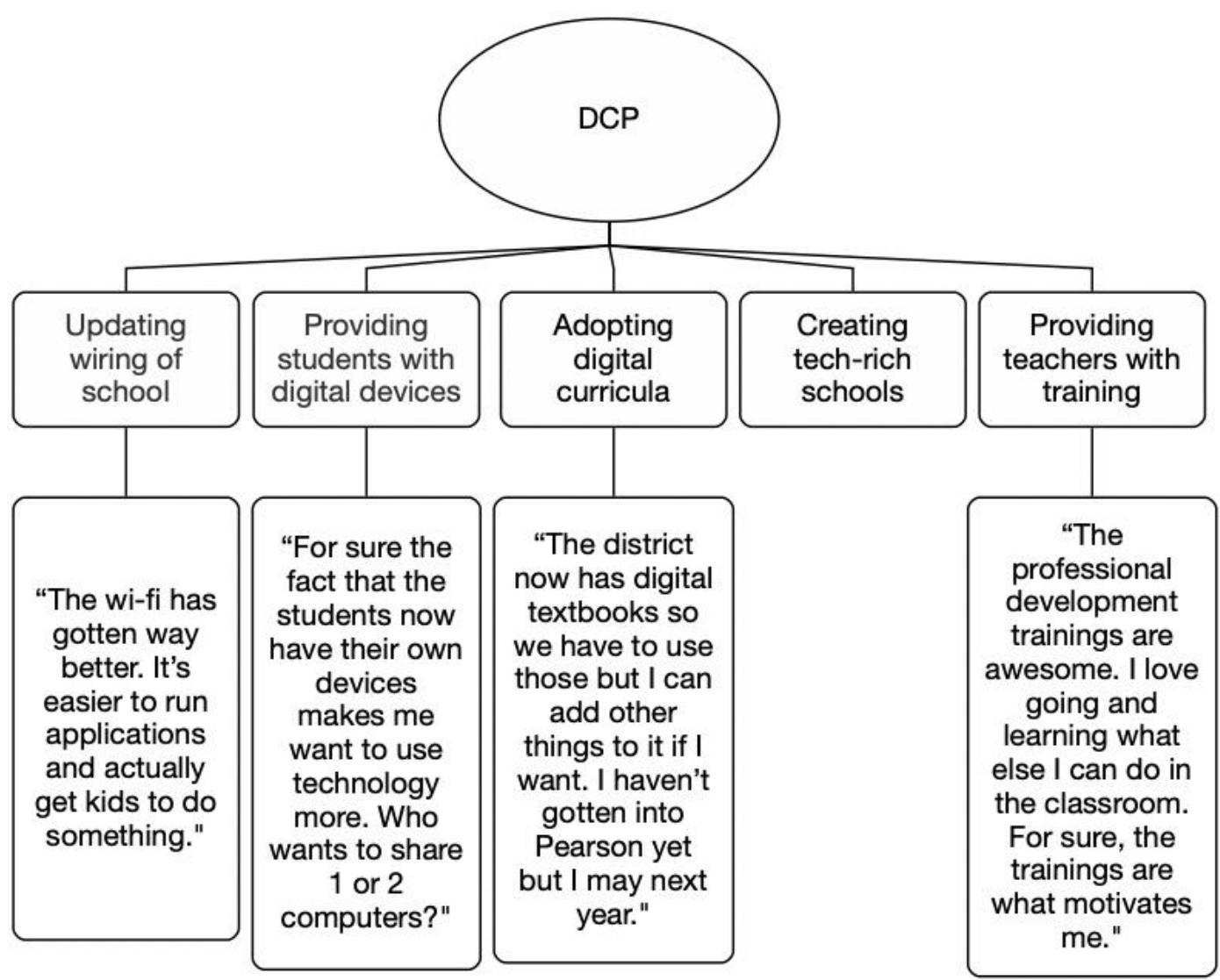

Figure 8: Flowchart representing how barriers to integration were addressed by the Digital Convergence Plan (2013).

These are barriers that are external to the teacher and as Ertmer (1999) referenced, these barriers are easier to address because they are usually tangible. These are milestones that are easily measured and that the district can mark as complete.

The second-order barriers are more difficult to measure because the teacher may or may not be aware of how their beliefs influence classroom practices. In regard to factors that prevent teachers from integrating technology into the classroom, Ertmer (1999) included teachers' self-efficacious beliefs regarding their ability to integrate 
technology into the classroom, beliefs about how the technology enhances the curriculum or supports learning, beliefs on what the role of the teacher and student in the classroom should be, and assessment processes. The 2 nd order barriers were not evident in the responses of the teachers who participated in this study..

During the interview process with the teachers, discussions about learning how to use the technology more effectively and how to integrate it into the learning activities did not occur. Teachers discussed how they used what they had and the reasons why they did not use technology in certain classrooms. Although this could be a barrier in other classrooms, the teachers in this study did not provide this information.

Ertmer's first order and second-order barriers to technology integration are still relevant, these barriers are not all-inclusive and deficient. In building on the theory of first-order and second-order barriers, Tsai and Chai (2012) introduced a third-order barrier. This barrier refers to the teacher's lack of instructional planning in regard to how the technology fits into their curriculum. Tsai and Chai (2012) state, assuming that firstorder and second-order barriers were removed from the teaching environment if teachers still do not have direction on how to plan and organize rich learning experiences for students with the new technologies they still will not implement technology. This third barrier was also present in my study. Teachers in this study expressed not having enough time or knowledge as to how the technology works and how they can incorporate it into their own classroom management. Two teachers reported the desire to use more technology in their classroom, they just needed to see how it would fit for more advanced learners. 
Similar barriers to Ertmer's (1999) identified 1st order barriers were mentioned by the teachers who were interviewed, as seen below. The spaces marked with a question mark (?) indicate areas that are not readily identifiable. This presented an opportunity to develop a new barrier, the fourth barrier to technology integration.

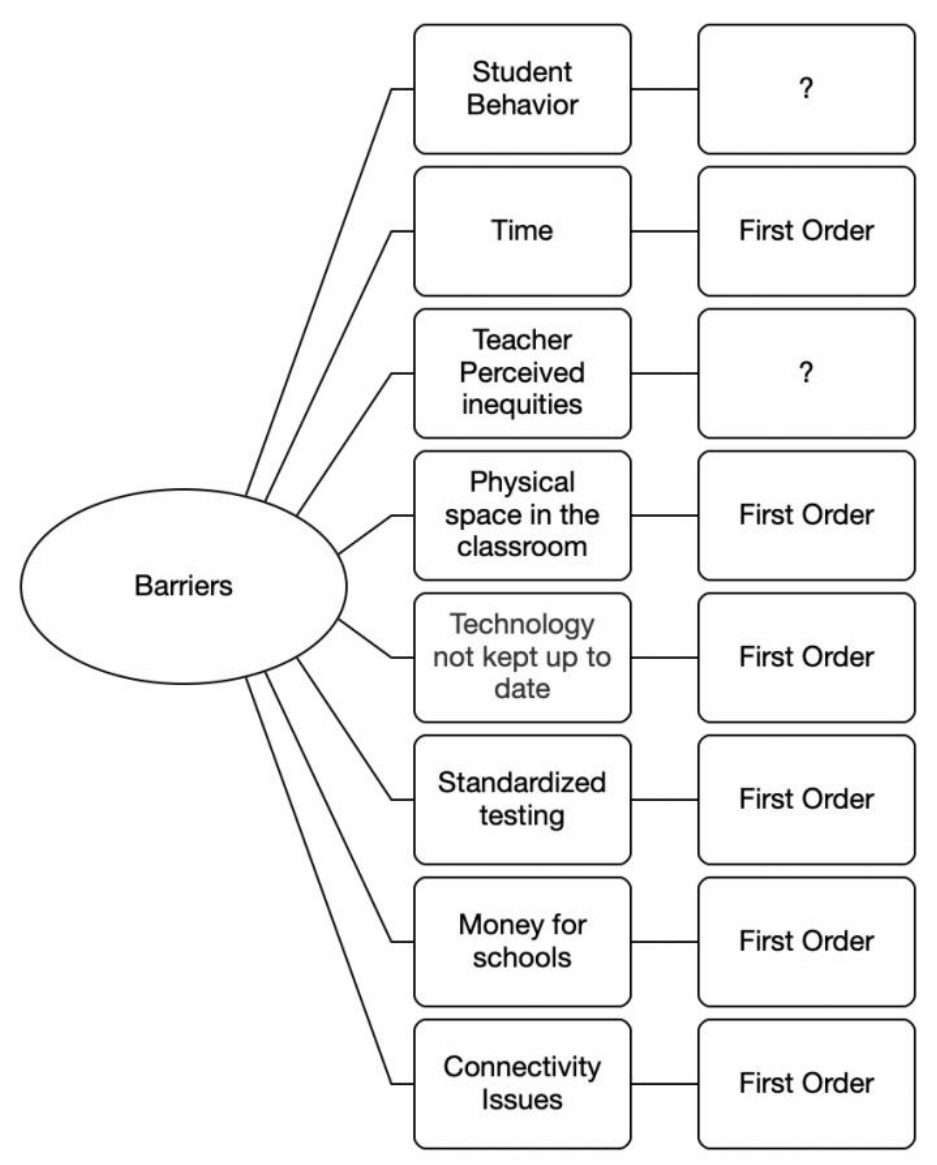

Figure 9: Flowchart representing the classification of teacher concerns into Ertmer's (1999) First Order and Second Order barrier. 


\section{Fourth Order Barrier}

As a result of the data collected during this research study, I would like to introduce a fourth barrier in order to address the lack of categorization for two of the areas represented in the graph above. This barrier refers to teacher perception of his/her students. Teacher perception was a distinct barrier to how technology was integrated into the classroom. For example, Sandra, George, and Albert all discussed how their teaching strategies and level of technology integration differed in accordance with the types of learners enrolled in each classroom environment. Lower level technology integration, as described by the SAMR model, typically included PowerPoints or a Smart Board for projecting assignment and content. This type of integration does not encourage students to think critically nor to construct their own understandings. The lower level integrations described by participants in this study consisted of teacher led lectures with the presentation slides being used only for holding content. Higher-level technology integration typically included students engaging in virtual tours, creating assessments for their peers, using coding applications, and engaging in collaborative research. In classrooms where the student population met certain conditions, teachers opted to not use technology that promoted higher-order thinking skills when they ordinarily would with a class population who did not meet those same conditions. Some of these conditions included: high inclusion population classrooms, academically atypical performance, increased need for behavior redirection and increased need for classroom management. In regard to atypical academic performers, this included both lower-achieving and higher achieving students. Students who were either English Language Learners or placed in Advanced courses received less instruction with more advanced types of technology. For 
example: creating political cartoons, participating in Escape Rooms, creating interactive reports and presentations, and engaging in virtual tours of other countries. Lower-level technology instruction was typically still used to facilitate discussion of curricular content.

When teacher perception impedes student learning it becomes a violation of the students' rights. In 1990, Contreras and Lee suggested that teachers actually contribute to the widening of the academic gaps through what they call "negative discrimination" (p. 434). Negative discrimination is the "reacting prejudicially to children as members of low-status categories" (Contreras \& Lee, 1990, 434). The low-status can refer to either low socioeconomic backgrounds or having a minority status. When a teacher has a specific perception towards his or her students, it affects student-teacher relationships, it negatively impacts the students' self-efficacy and hinders learning (Neel, 2017). When a teacher who would ordinarily use technology in a classroom to help those children develop essential skills for 21 st-century success and do not allow other students the same opportunity because of classroom-specific cultures and conditions, the issue of equitable access comes into question. Additionally, the incorporation of standards and how these standards are taught amongst the different levels of learners also represents inequity. For example, as teachers stated in their interviews, students in A.P. courses receive less instruction with technology because teachers perceive their curriculum to be so rigid and not have time for technology. The teachers also indicated that lower-performing students required more direct instruction time with the content in order to score better on the state tests and end of course exams, and so more of a focus is put on following the pacing guides. Teachers who worked with this group expressed hesitation in moving away from 
the prescribed curriculum because if students scored low on their exams, it reflected poorly on the teacher. As Linda McNeil states, "standardization reduces the quality and quantity of what is taught and learned in schools (2002, pg. 3). Using predetermined pacing guides and curricula which aligns with standardized tests limits the quality of teaching, reduces the role of the teacher in the classroom, and forces students into more passive learning styles (McNeil, 2002). In fact, McNeil (2002) continues to say, "over the long-term, standardization creates inequities, widening the gap between the quality of education for poor and minority youth and the of more privileged students (p. 3). This is the opposite of what the school system is trying to do by providing all students and all teachers with technologies that can enhance teaching and learning in order to close the achievement gap.

Finally, the students who are part of class in which teachers felt the some or all students would not benefit from the more advanced integration of technology and resorted to more passive teaching styles (like a PowerPoint), were never even exposed to higher-order thinking activities using the tools provided to them by the county.

Teachers who felt that particular groups of students were not capable of learning how to use or how to manage using technology or who would take too long in learning the technology engaged in what McNeil (2002) refers to as defensive teaching. In defensive teaching, teachers simplify a standardized curriculum in order to for students to recognize and/or retain the content they need for testing. "Student assignments were reduced to taking notes on lectures, copying lists from the blackboard, filling in blanks on worksheets, and reading one or two pages on the subject" (McNeil, 2002, p.14). Teachers need students to perform well because of teacher performance evaluations are tied to the 
data from the student testing, and "data use may open or close doors for students" (Datnow \& Park, 2018, p.135). Although McNeil's research is older, my study still reflects this. For example, this concept aligns with what George said during his interview "In classes where using tablets or games or other fun stuff is just not an option because of the types of students in the class (non-English speakers, classes with poor behavior management), I go over a PowerPoint and expect them to take notes. Then we do a few worksheets and I ask a few test-style questions at the end. Basically, prepare them for the test they are going to have to take in April". Although this teacher attempted to facilitate the content for the students, his predetermined perception of their ability impedes upon the students' rights and opportunity to engage in higher-order thinking activities. This prevents him from really pushing them to think critically and be active participants in the construction of their own learning. Please recall, this teacher will and has implemented higher order thinking activities involving the use of technology in his other classes. Therefore, this is not a limitation of the teacher but yet a limitation on the perception of students in that specific primary learning environment. It is merely the teachers trying to meet the "bureaucratic requirements of schooling" (McNeil, 2002, p. 15). This testing is required for schools to show accountability to the district and to the state, but as McNeil (2002) continues to say, “accountability throughout a state's educational system, the negative effects fall most heavily on the poorest children, minority children whose entire school experience comes to be dominated by an attempt to raise their test scores at any cost” (p.15). The students George was referring to attended a Title I school and most received free or reduced lunches. 


\section{Digital Equity}

Digital divide vs. digital equity. The digital divide is a term that was used in the 1980s to describe how gaps in access to computers and the internet affected groups of individuals based on socio-cultural factors such as race, gender, socioeconomic status, primary spoken language, disability and other social or cultural factors that could prevent access. At first, the term digital divide was being used to create an awareness about the disparity of physical and tangible access to computers and related technologies such as the internet, but the term was limiting of other relevant factors. According to the digital divide, if an individual had physical access to a computer or the internet either at home or school then it was perceived the individual had access (Gorski, 2009).

Around the 1990s, a more critical perspective on the digital divide began to situate the concept of the haves and have-nots around greater socio-cultural factors such as race, classism, and gender differences. The term digital divide did not encapsulate other, more complicated, inequities surrounding access or a lack thereof (Gorski, 2009). For example, gender-based technology differences (gender stereotyping) is a phenomenon that is not captured by the digital divide. There is a stark difference in how male students and female students use the internet (Singh, 2017). By 2022, it is estimated that about $60 \%$ of global Gross Domestic Products will be digital. This has great implications on societal, educational, and cultural preparation for all students, specifically that educational and technological resources are distributed equitably (Kuroda, Lopez, Sasaki, and Settecase, 2019). If educational and technological resources are not distributed equally then female students are at-risk of "losing out on the positive promise of full participation in digital economies" (Kuroda, Lopez, Sasaki, and Settecase, p. 1, 
2019). Structural factors, societal expectations and cultural norms hinder girls from pursuing technology use because from early years the perception that technology is a male dominated field is perpetuated in schools (Anderson, 2015). Although girls and boys may have equal physical access to technology, the discouragement of use by girls makes it unequitable. Racial differences in how technology is used and being accessed exists between Whites, African-Americans, and Hispanics.

Access and use to technology do not stop in the classroom, technology related jobs continue to be sought after. Technology workers are people who work for computer system design firms and are responsible for creating the hardware and developing software for public and private use (lawinsider.com). In 2019, Apple reported that 49\% of its tech-workers were White. This compared to 23\% Latin/Hispanic and 6\% Black/African-American. Facebook reported $40 \%$ of their tech-workers were White, in comparison to $4 \%$ Latin/Hispanic and less than $2 \%$ Black/African-American. Finally, Microsoft reported 51\% of their tech-workers were White, 5\% Latin/Hispanic and less than 4\% Black/African-American. This data was compared against their 2014 statistics which showed less than a $2 \%$ increase in Latin/Hispanic and Black/African-American employees with a more significant increase in the hiring of Asian employees, and a steady hire rate of White Americans (Harrison, 2019).

There are also significant disparities among users when looking at internet access at home. According the NCES Report for 2019, on a national level, in 2017 64\% of children ages 3-18 had physical access to the internet at home. This was up from $61 \%$ in 2015. $14 \%$ of children ages 3-18 did not have internet access at home. $67 \%$ of White 
children used the internet at home, $59 \%$ of Hispanic children, and $58 \%$ of Black children used the internet at home. This showed an increase in physical access for all groups. The report states that the White-Hispanic gap for home internet was smaller in 2017, and White-Black gap was also smaller. The report reflects that the more income a family had the more likely the children were to have internet access at home. Only $49 \%$ of children living in poverty had access to the internet at home. The main barrier reported for no home access for all groups was that the cost was too high. The digital divide's sole concentration is on physical access to the internet or related components. It does not include other factors such as societal, cultural, structural or other forms of inequities that prevent children from using technology.

In order to be more inclusive of the inequitable struggles that groups of people face, a different term needs to be used. The term digital equity emerged from looking at issues of access from a more critical, inclusive lens. Digital equity is a movement that expands the concept of the digital divide of just having physical access to one that aims to remove systemic inequities that hinder access such as race, sex, gender, class, linguism, and other forms of oppression (Gorksi, 2007). Gorksi (2007) states using the term digital divide is problematic because it is too simplistic and perpetuates the cycle of oppression and power, because it indicates that the only reason for not having access is due to a lack of physical resources.

Digital equity in context. Digital equity is a social justice movement aimed at ensuring that all people have access to information and communication tools (Solomon, Allen, and Resta, 2013). There are three main goals of digital equity. These are to 
challenge that technology and computer use is an "equalizer" of society, to bring to light how promoting computer use in education is actually advancing a cycle of inequities, and discussing how access means more than just physical access and it includes socio-cultural and political factors that inhibit access as well (Gorski, 2007). The National Institute for Community Innovations (2003) stated although access is important, equally important are the other dimensions of digital equity which include effective use of teaching and learning, access to high quality and culturally relevant content as well as the opportunity to engage in active, higher-order thinking activities as opposed to passive learning. In order to effectively address the various factors related to digital equity, there are prevailing principles of the movement (Gorski, 2007).

The Digital Convergence was implemented to support the integration of technology into schools and to increase physical access to technology for each student. This aligns with the first principal of digital equity. With this level of access all students. should be encouraged to use technology in ways that advances the student's personal and academic development. Additionally, all students should have access to convenient hardware, software, and supporting infrastructure in Miami Dade County Public Schools. This notion addresses the issue of only the wealthy or privileged having convenient access to technology and related components in their home. The Digital Convergence Plan (2013) addresses this understanding by increasing bandwidth in schools and providing students who do not have physical access to devices or internet at home with mobile technology and with portable hotspots sponsored by Sprint. Students from various grade levels and subject areas are provided with tablets and laptops which addresses to access to hardware. 
"The sexist, racist, heterosexist, and other oppressive dynamics observable offline are equally observable online" (Gorski, 2007, p.459). Equitable access can only exist when all people can safely and comfortably use the internet and software content without feeling oppression or devalued as a contributing member of society. One interviewee said that just by reviewing the software suggested for his use by the district, he was able to tell that the developer was most likely White from middle America, and he was not going to subject his students to a one-sided perspective. In this case the teacher is acting in a way that promotes digital equity by not exposing his students to the perpetual notion that there is one dominant culture.

Digital equity supports children using technology, but it must be done in a way that is developmentally and pedagogically appropriate. Gorski (2007) states that just having computers in each classroom is not enough when "some teachers (predominately those at mostly white wealthy schools) use them to encourage critical and creative thinking skills while others (predominately at schools with large percentages of students of color and students in poverty) use them to replicate the skills-and-drills and lowerlevel thinking activities" (p.460). This would include marginalized students who are typically identified as such because of social or cultural characteristics. Gorski (2007) posits that in order to avoid this type of instruction, all teachers should have access to professional development on how to incorporate advanced technologies in the classroom and into teaching practices. In the present study, although teachers reported having access to professional development workshops and opportunities, they still reported their use of technology and related activities differed depending on the population of students within each class. Teachers were more likely to use technology in classrooms that were easier to 
manage and where they perceived that the students were easier to teach. They expressed they were less likely to use new technologies and technologies that encouraged higherorder thinking skills with both advanced placement classes and classes with low performing students. They reported that they used PowerPoint presentations to lecture students. Classes where the majority of the students were non-English speakers, that mainstreamed students with disabilities alongside typically performing students, and that required behavioral redirection contain the marginalized students who do not have access to technology in order to participate in the higher order learning activities. Students in these classes who are not considered marginalized become marginalized by association.

Digital equity suggests that all users must have access to culturally relevant materials. Miami-Dade County Public Schools provides families with opt-in program information such as their 1:1 program (individual access to mobile devices), mobile hotspot access, voluntary program participation forms, and other related documents in English, Spanish and Creole. Other language translations are available upon request. The district is attempting to provide all families with access to information in their native languages. In this study, however, only one teacher reported using a software for Spanish speaking students that helped translate news articles. The cultural relevance of the students in this study's classroom environments is not being supported.

Digital equity questions the connection between the globalization of technology and the larger global community - and how this globalization of technology continues to promote those who already experience certain levels of privileges in the social, cultural, and economic dimensions. By perpetuating the systemic marginalization of certain 
groups of children we are preventing them from accessing and contributing to the global community. In order to reach true digital equity students need to be connected to the globalization of technology and the larger global community. This implication of learning how to function with technology and participation in the global community was in part represented during teacher interviews with references to preparing students for the workforce and the future. While some teacher responses reflected the need for preparing students for a future workforce, the purpose of the preparation did not originate with the principle of equity in the larger global community.

The data supports that teachers made conscious decisions to promote the development of learning with technology with certain groups of students who, in their opinion, were easier to teach. These decisions were made based on the community of students in each class. Data regarding the races, socioeconomic statuses, gender, nor primary language of the teachers or students were collected. It would be presumptive to conclude that teachers primarily made their decisions on whether or not to incorporate technology because of any single factor. What is evident is that all students within a class became marginalized because teachers made instructional or pedagogical decisions based on student characteristics.

Technology can be used as a tool for teachers to engage and stimulate students through innovative and exciting teaching practices for students who have limited access to it at home (Williamson, 2013). Students who do not have access to technology at home can still benefit from the interaction with technology by having access to it at school. The problem is that the same opportunity does not exist for all students because of decisions 
that are made by teachers within the classroom. As presented in this study, a lack of access can perpetuate inequities that students are already experiencing. "Digital equity occurs when all students have equal opportunity to benefit from modern information, communication and productivity tools" (Williamson, 2013, p. 192). In this study there were two main resources for technology use. The first was the implementation of the Digital Convergence Plan (2013) and the second was the classroom teachers. According to the data from this study, teachers received resources that were intended to promote technology integration into the classrooms. They reported that professional development was readily available and available online, that the infrastructure had been improved and internet access was not a problem, and that both hardware and software were readily accessible. These are resources mostly addressed the digital divide, or the physical access. The discussion of digital equity becomes relevant when the actual integration into the learning environment is explored. Teachers are making intentional decisions regarding which groups of students are going to engage in higher-order thinking activities using technology and related devices. The students who were marginalized include students who did not speak English, who had disabilities and were mainstreamed with typically performing students, classrooms which needed much behavioral redirection, and classrooms where students were atypical learners - either advanced placement or remedial. Even though the school district is moving closer to reducing disparities in physical access, equitable issues related to access still remain. As Resta and Laferriere (2015) state, in order to effectively address digital equity, it is imperative that specific groups of people are not left out. "Efforts to move toward digital equity must also be 
mobilized, focused, and coordinated to prevent the development of a permanent underclass in a global society" (Resta, 2011).

\section{Implications}

Implications for theory. As this study uncovered, the ultimate decision as to how technology is going to be used in the classroom rests on the teacher and is influenced by bureaucratic policies and learning environments. In order to address digital equity and to ensure that students have equitable access to the technologies that are being made available to them by government entities, the teachers need to fully understand the implications of their decisions and teaching strategies in the classroom. Digital equity cannot be effectively addressed without creating a partnership with teachers and giving them the opportunity to engage in meaningful learning tactics, which requires a reprieve from the standardization of content, standardization of pacing guides and standardization of assessments.

Tsai and Chai (2012) state that a barrier to technology integration is that teachers do not know how to effectively incorporate hardware and software into their lessons. If teachers who were willing to use technology, knew how to use it then they would be more inclined to do so. Miami Dade County Public Schools has indicated in the Digital Convergence Plan (2013) that teachers should be using the SAMR model when integrating technology into their learning activities. However, there is a disconnect between the expectations of the Digital Convergence Plan (2013) and the trainings that teachers are receiving. Teachers in this study were unaware of the SAMR model and that there was even a framework in which to align their learning activities to. Teachers experience this 3 rd order barrier because of the way that the plan is written and the way 
the plan is being implemented. If teachers were aware of the SAMR model and the connection it has to their professional development workshops, then this barrier could be addressed and teachers could then effectively align their lessons with higher order learning activities.

The teachers in the study were ultimately able to decide if and how they would integrate technology in their classrooms. Depending on the conditions of the classroom, each teacher would make an executive decision as to if certain groups of students would be given the opportunity to engage in higher-order thinking activities using technology. These decisions were based on the teachers' perceptions of the students' abilities, their academic standing (atypical vs. typical), behavior management, and at times, even academic interest. This study introduces a fourth-barrier to technology integration that should be further studied. This fourth barrier has to do with how teachers perceive their students and how that perception is either a barrier or facilitator to technology integration. The perception is specific to each group of students and not necessarily the teacher. That is what separates this fourth barrier from Ertmer's (1999) second barrier to technology integration. In her second barrier, Ertmer (1999) suggests that these barriers are personal to the teacher. These can be about the teachers' beliefs or self-efficacy in regard to technology integration, or not knowing how to use technology in the classroom. This fourth discriminating as to which groups of students should have access or whom they perceive to benefit from the access of technology into their learning activities.

Implications for practice. This study intended to identify how social studies teachers were using technology in their classrooms as well as potential barriers and facilitators. If government agencies are allocating monies for technology integration in 
schools in order to close the digital divide, it would be necessary to explore the experiences and challenges of the teachers. As a result of the interviews, it is determined that the Digital Convergence Plan (2013) enacted by Miami Dade County has increased access to resources such as tablets, mobile hotspots for students, teacher professional development trainings, and improved infrastructure but there is still a notable hesitancy on the part of the teachers. Unfortunately, teachers face amounting pressures for students to score well on their standardized and end of course exams as this is tied to their own annual teacher evaluations.

The SAMR model focuses on instructional practices by the teacher and is not student centered, it is teacher centered. Since the Digital Convergence Plan (2013) incorporates the SAMR model for technology integration, the plan does not contribute to digital equity, as digital equity is a student-centered movement. Because it is hierarchical, this model is also criticized for being linear. As a result, technology integration becomes a step by step implementation process not a student development process. If the Digital Convergence Plan (2013) were to be reconstructed, developers should consider using a different model in which to align teaching practices to. The TPACK model could help address the 2 nd order and 3 rd order barriers by improving teacher self-efficacy with helping them see their role in holistically developing the child. In referring to Gorski's (2007) principles of digital equity, all people should have access to information and communication tools in order for there to be justice. If teachers are not using these tools with certain groups of students then there is no justice. 
Additionally, teachers reported that having blended learner classrooms impeded upon their ability to effectively integrate technology into their lessons. This appears to be an opportunity for additional training specific to these types of circumstances. The professional development workshops that teachers reportedly attended had to do with how to use new software and hardware, and although this is useful, there seems to be a need for pedagogical training as well. Pedagogically speaking, technology can have an immense impact on students with disabilities or students who are learning English. If teachers were made aware of the impact that using technology with at-risk groups can have on their learning and development, they may be more inclined to use it as opposed to running from it.

Finally, this study uncovers the need for continuous improvement in regard to professional development. Teachers may not be aware of how to access the workshops or how to identify which workshops provide a stipend for substitute coverage. Teachers may also need to be trained on how to request access to these trainings, since there are instances in which principals are not allowing teachers to attend. Another area that should be improved in regard to professional development, is the types of workshops that are being conducted. Although the district right now offers teachers workshops on how to use software and hardware, it may be beneficial to include sessions on how technology can help different groups of students. If teachers feel they are helping students by not exposing them to technology, maybe if they learned the positive impact it can have on learners, they would be more inclined to change their teaching practices and start to expose all of their students to higher-order activities. 
Implications for research. This study implies that Ertmer's (1999) theory on first order and second-order barriers as well as Tsai and Chai's (2012) third order barriers are still applicable in today's teaching environment. Teachers who participated in this study identified very similar obstacles to technology integration almost 20 years later. The incorporation of the Digital Convergence Plan (2013) has addressed many of these obstacles and has actually facilitated the integration of technology into the classroom. Even with this though, there are still areas that are not being addressed. These areas include teacher perception towards collective groups of students. In a multicultural environment, teachers are not going to use software that is exclusionary or unrelatable for students.

\section{Limitations and Recommendations}

There were limitations to this study that should be noted. First, due to the timing of the study (March-April) teachers were preparing for their end of course exams and other state tests. Although participants made themselves available, scheduling interviews and follow up interviews was difficult. Secondly, although I had reached saturation by the seventh interview, identifying teachers who were willing to participate in the study was difficult. I feel the study would have benefitted from including a more diverse group of teachers. Types of diversity that would have preferably been included are teachers who teach in both high and low socioeconomic schools, teachers from a variety of ethnic and cultural backgrounds, a variety of teaching environments (Special Education, English as a Second Language, etc.), and teachers with varying years of experience. Also, not all teachers were comfortable with the Zoomø platform and may not have fully expressed themselves the same way as if the interview were held in person. Accessing the Zoom $\odot$ 
platform was challenging for some teachers and by the time they finally logged on, a lot of interview time was taken up and final questions had to be rushed. A further level of analysis such as non-verbal cues could have been produced through face to face interviews.

Another limitation of the study is that demographic information relating to the teachers nor students were collected. If this information had been collected and analyzed, there may have been an opportunity to see if racial or social discrimination was a specific factor in this unequitable use of technology. As presented in Critical Race Theory, the primary factor of inequality is race (Gillborn, 2006). Although Critical Race Theory (CRT) was initially rooted in the legal system, it is a perspective that has made its way outside of the legal system and into other facets of society - such as education. Tate (1997) states, one cannot discuss the marginalization of people of color in education without discussing their marginalization in politics and society. Future researchers should collect demographic information of both teachers and students to see if race, or other levels of discrimination such as gender, play a specific role in digital inequity.

In the future, more teachers should be recruited to participate in interviews. I also think that adding a focus group would be helpful because many teachers had similar experiences and they expressed that they were not sure if other teachers were experiencing the same things. Some of the teachers felt isolated in their struggles and using a focus group may allow the researcher to further explore some of those issues.

\section{Conclusion}

The outcome of the study and the implications for future researchers were completely unanticipated by me. Children are dependent on adults in order to guide them 
and help them develop into responsible citizens. When teachers choose to not expose children to certain learning experiences that they are exposing other students to it is an injustice to them and the injustice of our school system. All children should have an equitable opportunity to learn in a way that is going to prepare them for success. If the county is making resources available to schools, administrators, and teachers, it is not fair that some students are benefitting from this and others are not. There continues to be a disparity in access and use, even when resources are being implemented into schools. The results of this study demonstrate that the gatekeeper to student success is the teacher, and not all teachers are equipped with the skills to teach all students, much less prepare them with the necessary 21 st century skills. 


\section{References}

Attewell, P. (2001). Comment: The first and second digital divides. Sociology of Education, 74(3), 252-259.

Anderson, N. (2015). Digital technologies and equity: gender, digital divide and rurality. Teaching and digital technologies: Big issues and critical questions, 46.

Ayas, C. (2006). An Examination of the Relationship between the Integration of Technology into Social Studies and Consructivist Pedagogies. Turkish Online Journal of Educational Technology-TOJET, 5(1), 14-25.

Barrow, E., Anderson, J., \& Horner, M. (2017). The role of photoblogs in social studies classroom: Learning about the people of the Civil War. Contemporary Issues in Technology and Teacher Education, 17(4), 504-521.

Berson, I., Berson, M., \& McGlinn Manfra, M. (2012). Touch, type, and transform: iPads in the social studies classroom. Social Education, 76(2), 88-91.

Bitner, N., \& Bitner, J. O. E. (2002). Integrating technology into the classroom: Eight keys to success. Journal of Technology and Teacher Education, 10(1), 95-100.

Bolick, C. M. (2008). Technology integration: The Trojan horse for school reform. Technology and social studies research, 173-187.

Brickner, D. (2018). The effects of first and second-order barriers to change on the degree and nature of computer usage of mathematics teachers: A case study. ETD Collection for Purdue University.

Brush, T., Glazewski, K. D., \& Hew, K. F. (2010). Development of an instrument to measure preservice teachers' technology skills, technology beliefs, and technology barriers. Computers in the Schools, 25(1-2), 112-125.

Butler-Pascoe, M. E., \& Wiburg, K. M. (2003). Technology and teaching English language learners. Boston: MA: Allyn and Bacon.

Chai, C. S., \& Kong, S. C. (2017). Professional learning for 21 st century education. Journal of Computers in Education, 4(1), 1-4.doi: 10.1007/s40692016-0069

Carver, L. B. (2016). Teacher perception of barriers and benefits in K-12 technology usage. Turkish Online Journal of Educational Technology-TOJET, 15(1), 110116. 
Charmaz, K. (1996). The search for Meanings-Grounded Theory. In, Smith, J.A., Harre, R., \& Van Langenhove L.(Eds.), Rethinking methods in psychology (pp. 27-49).

Charmaz, K. (2006). Constructing grounded theory: Methods for the 21 st century. UK: SAGE.

Charmaz, K. (2014). Constructing grounded theory. Sage.

Charmaz, K., \& Belgrave, L. L. (2007). Grounded theory. The Blackwell encyclopedia of sociology. New York, NY: Sage Publications.

Chen, C. H. (2008). Why do teachers not practice what they believe regarding technology? integration? The Journal of Educational Research, 102(1), 65-75.

Clinton, William J. (1997b), "Remarks by the President at Education Announcement/Roundtable," The East Room, The White House, Office of the Press Secretary, April 2. Retrieved from: http://www.iitf.nist.gov/documents/press/040297.htm

Collin, S., \& Brotcorne, P. (2019). Capturing digital (in) equity in teaching and learning: a sociocritical approach. The International Journal of Information and Learning Technology, 36(2), 169-180.

Contreras, A., \& Lee, O. (1990). Differential treatment of students by middle school science teachers: Unintended cultural bias. Science Education. 74(4), 433-444. doi.org/10.1002/sce.3730740404

Cuban, L. (1993). Computers meet classroom: Classroom wins. Teachers College Record, 95(2), 185-210.

Darling-Hammond, L. (2000). Teacher quality and student achievement. Education policy analysis archives, 8,1 .

Datnow, A., \& Park, V. (2018). Opening or closing doors for students? Equity and data use in schools. Journal of Educational Change, 19(2), 131-152.

Davies, R. S., \& West, R. E. (2014). Technology integration in schools. In Handbook of research on educational communications and technology (pp. 841-853). Springer, New York, NY.

Davis, T., Fuller, M., Jackson, S., Pittman, J., \& Sweet, J. (2007). A National Consideration of Digital Equity. International Society for Technology in Education (ISTE). 
Digital Classrooms Program Plans \& Allocation. Retrieved from:

http://www.fldoe.org/about-us/division-of-technology-info-services/educationaltechnology/dcp.stml

Doering, A., Veletsianos, G., Scharber, C., \& Miller, C. (2009). Using the technological, pedagogical, and content knowledge framework to design online learning environments and professional development. Journal of Educational Computing Research, 41(3), 319-346.

Dolan, J. E. (2016). Splicing the divide: A review of research on the evolving digital divide among K-12 students. Journal of Research on Technology in Education, 48(1), 16-37. DOI:10.1080/15391523.2015.1103147

Doolittle, P. E., \& Hicks, D. (2003). Constructivism as a theoretical foundation for the use of technology in social studies. Theory \& Research in Social Education, 31(1), 72-104.

Dworkin, S. L. (2012). Sample size policy for qualitative studies using in-depth interviews. doi: https://doi.org/10.1007/s10508-012-0016-6

Ertmer, P. (1999). Addressing first-and second-order barriers to change: Strategies for technology integration. Educational Technology Research and Development, 47(4), 47-61.

Ertmer, P., \& Newby, T. (2013). Behaviorism, cognitivism, constructivism: Comparing critical features from an instructional design perspective. Performance Improvement Quarterly, 26(2), 43-71.

Ertmer, P., \& Ottenbreit-Leftwich, A. (2013). Removing obstacles to the pedagogical changes required by Jonassen's vision of authentic technology-enabled learning. Computers \& Education, 64, 175-182.

Ertmer, P., Ottenbreit-Leftwich, A., Sadik, O., Sendurur, E., \& Sendurur, P. (2012). Teacher beliefs and technology integration practices: A critical $r$ elationship. Computers \& education, 59(2), 423-435.

Eubanks, V. (2012). Digital dead end: Fighting for social justice in the information age. MIT Press.

Espinoza, Oscar. (2007). Solving the Equity-Equality Conceptual Dilemma: A New Model for Analysis of the Educational Process. Educational Research - EDUC RES. 49. 343-363. 10.1080/00131880701717198.

Firmin, M. W., \& Genesi, D. J. (2013). History and implementation of classroom technology. Procedia-Social and Behavioral Sciences, (93) 1603-1617. 
Freire, P. (1996). Pedagogy of the oppressed (revised). New York: Continuum.

Fulton, K., \& Sibley, R. (2003). Barriers to equity. Toward digital equity: Bridging the divide in education, 14-24. Chesapeake, VA.

Funkhouser, B. J., \& Mouza, C. (2013). Drawing on technology: An investigation of preservice teacher beliefs in the context of an introductory educational technology course. Computers \& Education, 62, 271-285.

Gillborn, D. (2005). Education policy as an act of white supremacy: Whiteness, critical race theory and education reform. Journal of Education Policy, 20(4), 485-505.

Glaser, B.G. (1978). Theoretical sensitivity. Sociology Press.

Glaser, B. G. \& Strauss, A. L. (1967). The discovery of grounded theory: Strategies for qualitative research. Chicago: Aldine Publishers.

Gopalan, V., Bakar, J. A. A., Zulkifli, A. N., Alwi, A., \& Mat, R. C. (2017). A review of the motivation theories in learning. In AIP Conference Proceedings (Vol. 1891, No. 1, p. 020043). AIP Publishing.

Gordon, J., \& Patterson, J. A. (2013). Response to tracy's under the "Big Tent" establishing universal criteria for evaluating qualitative research. Qualitative Inquiry, 19(9), 689-695.

Gorski, P. (2007). Digital Equity. In G. Anderson \& K. Herr (Eds.), Encyclopedia of activism and social justice, volume 1. Thousand Oaks, CA: Sage Publications.

Gorski, P. C. (2009). Insisting on digital equity: Reframing the dominant discourse on multicultural education and technology. Urban Education, 44(3), 348-364.

Hamilton, E. R., Rosenberg, J. M., \& Akcaoglu, M. (2016). The substitution augmentation modification redefinition (SAMR) model: A critical review and suggestions for its use. TechTrends, 60(5), 433-441. Doi: 10.1007/s11528-0160091

Harris, Charlyque Joy. The Effective Integration of technology into schools' curriculum. Distance Learning 13, no. 2 (April 2016): 27-37.

Harris, J. B., \& Hofer, M. J. (2011). Technological pedagogical content knowledge (TPACK) in action: A descriptive study of secondary teachers' curriculum-based, technology-related instructional planning. Journal of Research on Technology in Education, 43(3), 211-229. 
Harris, J., Mishra, P., \& Koehler, M. (2009). Teachers' technological pedagogical content knowledge and learning activity types: Curriculum-based technology integration reframed. Journal of research on technology in education, 41(4), 393-416.

Harrison, S. (2019). Five years of tech diversity reports - and little progress. Retrieved from: https://www.wired.com/story/five-years-tech-diversity-reports-littleprogress/

Heafner, T. (2004). Using technology to motivate students to learn social studies. Contemporary Issues in Technology and Teacher Education, 4(1), 42-53.

Hilton, J. T. (2016). A case study of the application of SAMR and TPACK for reflection on technology integration into two social studies classrooms. The Social Studies, 107(2), 68-73. DOI: 10.1080/00377996.2015.1124376

Howard, S. K., \& Mozejko, A. (2015). Teachers: technology, change and resistance. Teaching and digital technologies: Big issues and critical questions, 307-317.

International Society of Technology in Education. (2017). 2017 annual report. Retrieved from https://www.iste.org/docs/pdfs/iste-annual-report-2017.pdf?sfvrsn=2

Jonassen, D. H., Peck, K. L., \& Wilson, B. G. (1999). Learning with technology: A constructivist perspective. Upper Saddle River, NJ: Merrill.

Kalina, C., \& Powell, K. C. (2009). Cognitive and social constructivism: Developing tools for an effective classroom. Education, 130(2), 241-250.

Kleiman, G. M. (2004). Myths and realities about technology in K-12 schools: Five years later. Contemporary Issues in Technology and Teacher Education, 4(2), 248-253.

Kleinsasser, R. C. (2014). Teacher efficacy in teaching and teacher education. Teaching and Teacher Education, 44, 168-179.

Krahenbuhl, K. S. (2016). Student-centered education and constructivism: Challenges, concerns, and clarity for teachers. The Clearing House: A Journal of Educational Strategies, Issues and Ideas, 89(3), 97-105.

Kormos, E. (2019). An examination of social studies educators to facilitate preservice teacher development of technology integration. Contemporary Issues in Technology and Teacher Education, 19(1).

Kuroda, R., Lopez, M., Sasaki, J., and Settecase, M. (2019). The digital gender gap. Retrieved from: https://www.gsma.com/mobilefordevelopment/wpcontent/uploads/2019/02/Digital-Equity-Policy-Brief-W20-Japan.pdf 
Livingstone, S., \& Bulger, M. (2014). A global research agenda for children's rights in the digital age. Journal of Children and Media 8(4), 317-335.

Lo, J. C. (2015). Developing participation through simulations: A multi-level analysis of situational interest on students' commitment to vote. The Journal of Social Studies Research, 39(4), 243-254.

Martorella, P. H. (1997). Technology and the social studies - or: Which way to the sleeping giant?. Theory \& Research in Social Education, 25(4), 511-514.

McLeod, S. A. (2019). What is the Zone of Proximal Development? Retrieved from https://www.simplypsychology.org/Zone-of-Proximal-Development.html

Miami Dade County Public Schools. Retrieved from: dadeschools.net

Miami Dade County Public Schools, Organizational Charts. Retrieved from: hr.info.dadeschools.net

Molnar, M. (2018). Federal education spending bill would boost funding for Title IV, Career-Tech. Ed Week Market Brief. Retrieved from:

https://marketbrief.edweek.org/marketplace-k-12/federal-education-spending-billboost-funding-title-iv-career-tech/

Nation's Report Card. Retrieved from: https://www.nationsreportcard.gov/

National Council for the Social Studies. Socialstudies.org

Neel, E. (2017). Race, The Role Model Effect, and Bias in the Classroom at a

Predominantly White Institution (Doctoral dissertation).

Parker, W. C., \& Lo, J. C. (2016). Reinventing the high school government course:

Rigor, simulations, and learning from text. Democracy \& Education, 24(1), 1-10.

Passey, D., Shonfeld, M., Appleby, L., Judge, M., Saito, T., \& Smits, A. (2018). Digital agency: Empowering equity in and through education. Technology, Knowledge and Learning, 23(3), 425-439.

Patton, M. Q. (2002). Qualitative research and evaluation methods . Thousand Oakes.

Piaget, J. (1983). Piaget's theory. Handbook of child psychology, 1(4).

Reinhart, J. M., Thomas, E., \& Toriskie, J. M. (2011). K-12 teachers: Technology use and the second level digital divide. Journal of Instructional Psychology, 38(3/4), 181. 
Resta, P. (2011). TWG 4: Global awareness. Briefing paper presented at the EDUsummIT 2011 meeting, Paris.

Resta, P., \& Laferrière, T. (2015). Digital equity and intercultural education. Education and Information Technologies, 20(4), 743-756.

Rice, M. L., \& Wilson, E. K. (1999). How technology aids constructivism in the social studies classroom. The Social Studies, 90(1), 28-33.

Romrell, D., Kidder, L., \& Wood, E. (2014). The SAMR model as a framework for evaluating mLearning. Online Learning Journal, 18(2).

Ruggiero, D., \& Mong, C. J. (2015). The teacher technology integration experience: Practice and reflection in the classroom. Journal of Information Technology Education, 14.

Ryan, T., \& Bagley, G. (2015). Nurturing the integration of technology education. Journal of Theory \& Practice in Education (JTPE), 11(1).

Schuster, J. (2013). Miami-Dade school board authorizes digital convergence plan.Miami Dade County Public Schools. Retrieved from http://news.dadeschools.net/releases/rls13/147_digital.html

Shifflet, R., \& Weilbacher, G. (2015). Teacher beliefs and their influence on technology use: A case study. Contemporary Issues in Technology and Teacher Education, 15(3), 368-394.

Singh, S. (2017). Bridging the gender digital divide in developing countries. Journal of Children and Media, 11(2), 245-247.

Solomon, G., Allen, N. J., \& Resta, P. E. (Eds.). (2003). Toward digital equity: Bridging the divide in education. Boston, M.A.: Prentice Hall.

Stockwell, G. (2013). Technology and motivation in English-language teaching and learning. In International perspectives on motivation (pp. 156-175). Palgrave Macmillan, London.

Strauss, A., \& Corbin, J. M. (1997). Grounded theory in practice. New York, NY: Sage.

Tate IV, W. F. (1997). Chapter 4: Critical race theory and education: History, theory, and implications. Review of research in education, 22(1), 195-247. 
Tondeur, J., Van Braak, J., Ertmer, P. A., \& Ottenbreit-Leftwich, A. (2017). Understanding the relationship between teachers' pedagogical beliefs and technology use in education: a systematic review of qualitative evidence. Educational Technology Research and Development, 65(3), 555-575

Tracy, S. J. (2010). Qualitative quality: Eight "big-tent" criteria for excellent qualitative research. Qualitative inquiry, 16(10), 837-851.

Trilling, B., \& Fadel, C. (2009). $21_{\text {st }}$ century skills: Learning for life in our times. John Wiley \& Sons, 2009.

Tsai, C. C., \& Chai, C. S. (2012). The" third"-order barrier for technology-integration instruction: Implications for teacher education. Australasian Journal of Educational Technology, 28(6).

U.S. Department of Education (n.d.). Use of technology in teaching and learning. Retrieved from: https://www.ed.gov/oii-news/use-technology-teaching-andlearning

U.S. Department of Education (n.d.). U.S. Department of education. Retrieved from: https://www2.ed.gov/about/overview/budget/budget19/summary/19summary.pdf

Van Dijk, J. A. G. M. (2012). The evolution of the digital divide: The digital divide turns to inequality of skills and usage. Digital enlightenment yearbook, 2012, 57-75.

Van Roekel, D. (2008). Technology in schools: The ongoing challenge of access, adequacy, and Equity. NEA. Retrieved from https://www.nea.org/assets/docs/PB19_Technology08.pdf

Vasinda, S., Ryter, D. A., Hathcock, S., \& Wang, Q. (2017). Access is not enough: A collaborative autoethnographic study of affordances and challenges of teacher educators' iPad integration in elementary education methods courses. Contemporary Issues in Technology and Teacher Education, 17(3), 411431.

Warschauer, M., Knobel, M., \& Stone, L. (2004). Technology and equity in schooling: Deconstructing the digital divide. Educational policy, 18(4), 562-588.

Warschauer, M., \& Matuchniak, T. (2010). New technology and digital worlds: Analyzing evidence of equity in access, use, and outcomes. Review of research in education, 34(1), 179-225. 
Wei, L., \& Hindman, D. B. (2011). Does the digital divide matter more? Comparing the effects of new media and old media use on the education-based knowledge gap. Mass Communication and Society, 14(2), 216-235.

Williamson, A. (2015). Embedding Digital Advantage: A Five-Stage Maturity Model for Digital Communities. The Journal of Community Informatics, 11(2).

Yoo, J. H. (2016). The effect of professional development on teacher efficacy and teachers' self-analysis of their efficacy change. Journal of Teacher Education for Sustainability, 18(1), 84-94. 


\section{Appendix A}

Interview Questions for In-Service Teachers:

1. Which grade level are you currently teaching?

2. What do you like most about teaching?

3. When it comes to classroom teaching, what do you think the role of the teacher should be?

4. How do you feel about the push for integrating technology into the classrooms?

5. What do you know about technology use in the classroom?

6. Tell me what you think about technology use and the implications for the students?

7. In your classroom, who decides if and to what extent technology is used?

8. Which technologies do you have access to and how do you feel about them?

9. How do you feel about the resources that are available to you in regards to technology integration?

10. How do you feel about using technology and the impact it has on instructional time?

11. If you could design a classroom experience for students, is it one that would include or would not include the use of technology?

12. If you wanted to create that classroom experience we just discussed, would you have access to the resources you needed?

13. Thinking about your personal experiences, in your classroom, is there something that holds you back from really moving forward with technology integration?

14. Is there something that has really helped you?

15. Would you like to share anything else about the use of technology in the classroom, resources you have access to, or the implications technology has on students? 


\section{Appendix B}

Interview questions for follow-up interview with in-service teachers:

1. Is there anything that has resonated with you since our last meeting?

2. I wanted to share with you my analysis from our first meeting, please tell me if I have made a fair assessment.

3. Is there anything in my assessment that you would like to address?

4. Is there anything else that you would like to share before we conclude this interview? 
VITA

\section{STEPHANIE DELGADO}

Born, Miami, Florida

2001-2003

A.A., Early Childhood Education

Miami Dade College

Miami, Florida

2004-2006

B.A.,Psychology

Florida International University

2007-2010

M.S., Curriculum and Instruction

University of Florida

Gainesville, Florida

2016-2019

Doctoral Program, Curriculum and Instruction

Florida International University

Miami, Fl

\section{PUBLICATIONS AND PRESENTATIONS}

Oct. 2, Miami, Fl: YES YOU CAN: 3 Easy Steps to Creating a Low-Cost Quality Course" - InnovEd

Oct. 4, Miami, Fl: "Digital Content: Making School Affordable for Financially Strapped Students" - EdIT

Oct. 28, Grapevine, Texas: "YES YOU CAN: 3 Easy Steps to Creating a Low-Cost Quality Course” - QM Connect

Nov. 18, Orlando, Fl: "YES YOU CAN: 3 Easy Steps to Creating a Low-Cost Quality Course" - OLC Accelerate

Nov. 19, Orlando, Fl: "Using Personal Reflection and the Community of Inquiry Model for Fully Online and Hybrid Course Development" - OLC Accelerate

June 2018, Havana, Cuba: "Culture, Identity and Reciprocity: Training Teachers to be Students"- Caribbean Studies Association

Nov. 2016, Cleveland, Ohio: "Helping the Hidden Culture: How to Make Schools Better for Homeless and Highly Mobile Students" - Association for Multi-Cultural Education

2015, 2016, 2017, 2018: FIUCon. Multiple Sessions (Open-Ed Resources, Multiple Intelligences, Curriculum Design, and Affordability Counts) 
Oct. 4, Miami, Fl: "Digital Content: Making School Affordable for Financially Strapped Students" - EdIT

Oct. 28, Grapevine, Texas: "YES YOU CAN: 3 Easy Steps to Creating a Low-Cost Quality Course”- QM Connect

Nov. 18, Orlando, Fl: “YES YOU CAN: 3 Easy Steps to Creating a Low-Cost Quality Course" - OLC Accelerate

Nov. 19, Orlando, Fl: "Using Personal Reflection and the Community of Inquiry Model for Fully Online and Hybrid Course Development" - OLC Accelerate 